\title{
ESTUDO ULTRA-ESTRUTURAL E IMUNOCITOQUÍMICO DAS REAÇÕES DO PERIODONTO DE MOLARES DE RATOS SUBMETIDOS A ESTÍMULOS CONTÍNUOS DE VESTIBULARIZAÇÃO EM TEMPOS PROLONGADOS
}

Dissertação apresentada ao Instituto de Ciências Biomédicas da Universidade de São Paulo, para obtenção do título de Mestre em Ciências (Biologia Celular e do Desenvolvimento)

São Paulo 
NATASHA D'ANDREA MATEUS

\section{ESTUDO ULTRA-ESTRUTURAL E IMUNOCITOQUÍMICO DAS REAÇÕES DO PERIODONTO DE MOLARES DE RATOS SUBMETIDOS A ESTÍMULOS CONTÍNUOS DE VESTIBULARIZAÇÃO EM TEMPOS PROLONGADOS}

Dissertação apresentada ao Instituto de Ciências Biomédicas da Universidade de São Paulo, para obtenção do título de Mestre em Ciências (Biologia Tecidual e Tecidual).

Área de concentração: Biologia Celular e do Desenvolvimento.

Orientador: Prof. Dr. Victor E. Arana-Chavez

São Paulo

2009 
DADOS DE CATALOGAÇÃO NA PUBLICAÇÃO (CIP)

Serviço de Biblioteca e Informação Biomédica do

Instituto de Ciências Biomédicas da Universidade de São Paulo

(c) reprodução total

\section{Dandrea Mateus, Natasha.}

Estudo ultra-estrutural e imunocitoquímico das reações do periodonto de molares de ratos submetidos a estímulos contínuos de vestibularização em tempos prolongados / Natasha Dandrea Mateus. -- São Paulo, 2009.

Orientador: Victor Elias Arana Chavez.

Dissertação (Mestrado) - Universidade de São Paulo. Instituto de Ciências Biomédicas. Departamento de Biologia Celular e do Desenvolvimento. Área de concentração: Biologia Celular e Tecidual. Linha de pesquisa: Biologia dos Tecidos Mineralizados.

Versão do título para o inglês: Ultrastructural and immunocytochemical study of periodontal reactions to orthodontic continuous force in rat molars buccally applied for long periods.

Descritores: 1. Movimento ortodôntico 2. Remodelação óssea Osso alveolar 4. Osteopontina 5. Periodonto 6. Reabsorção radicular I. Chavez, Victor Elias Arana II. Universidade de São Paulo. Instituto de Ciências Biomédicas. Programa de Pós-Graduação em Biologia Celular e Tecidual III. Título. 
Candidato(a):

Título da Dissertação:

Orientador(a):
Natasha Dandrea-Mateus.

Estudo ultra-estrutural e imunocitoquímico das reações do periodonto de molares de ratos submetidos a estímulos contínuos de vestibularização em tempos prolongados.

A Comissão Julgadora dos trabalhos de Defesa da Dissertação de Mestrado, em sessão pública realizada a /...................................
( ) Aprovado(a)
( ) Reprovado(a)

Examinador(a): Assinatura:

Nome:

Instituição:

Examinador(a): Assinatura:

Nome:

Instituição:

Presidente: Assinatura:

Nome:

Instituição: 
À DEUS, pela vida e pela força divina que permitur a reatização desse trabalho.

Aos meus pais e irmão, José Carlos, Adenira e Rodolpho pelo amor incondicional, pelo incentivo na minha formaçã e por estarem sempre presente em minha vida. Obrigada pela força nos momentos dificeis. Amo muito vocês.

Ao Thates Marques companheiro e amigo, peto amor, carinho e apoio constante. 


\section{AGRADECIMENTOS}

Em especial, ao Prof. Dr. Victor Elias Arana-Chavez, meu orientador, por todos os ensinamentos, amizade, confiança e paciência. Exemplo de ética, serenidade e dedicação à docência. A ele, minha eterna gratidão por tido a oportunidade de ser sua aluna.

Aos meus amigos do Laboratório de Biologia dos Tecidos Mineralizados, Elizabeth Ferreira Martinez, Vivian Bradaschia-Correa, Daniela Janones, Márcio Cajazeira Aguiar, Newton Maciel Oliveira, Luciana Ferreira Massa, Fernanda Yamamoto, Tais Oliveira, Karla Resende, Fábio Seiji pela convivência e bons papos tornando a vida acadêmica mais enriquecedora. Agradeço em especial a amiga Tatiani Ayako Goto Donato, por todos os momentos que passamos juntas, pelas conversas, risadas e companhia na imunocitoquímica.

À minha amiga Lucienne Bonafe-Oliveira pela oportunidade de continuar esse estudo.

À Fernanda Ângela Correa Barrence, técnica do laboratório de Biologia dos Tecidos Mineralizados e amiga, pela ajuda em todos os momentos. Muito prestativa e presente na rotina do laboratório.

Ao Gaspar Ferreira de Lima e Edson de Oliveira técnicos dos setores de Microscopia Eletrônica e Fotografia. Obrigada pela ajuda na obtenção dos meus cortes, visitas ao microscópio eletrônico e fotografias.

A Celiana Sandreley Silva, secretária da Pós-Graduação do departamento de Biologia Celular e do Desenvolvimento do ICB da USP pela disponibilidade. 
Às amigas de Pós Graduação Ana Paula Zen Petisco Fiore e Eloiza Rezende que me acompanharam nesse período.

Ao Fernando e Cláudio, técnicos do Biotério, pelo cuidado com os animais.

Aos demais funcionários do Departamento de Biologia Celular e do Desenvolvimento pelo auxílio e disponibilidade.

E a todos que direta ou indiretamente participaram da realização desse trabalho. 
"Só existe dois dias no ano que nada pode ser feito. Um se chama ontem e o outro se chama amanhã, portanto hoje é o dia certo para amar, acreditar, fazer e principalmente viver." 


\section{RESUMO}

\section{D'ANDREA-MATEUS, N. Estudo ultra-estrutural e imunocitoquímico das reações}

do periodonto de molares de ratos submetidos a estímulos contínuos de vestibularização em tempos prolongados. 102f. Dissertação. São Paulo; Instituto de Ciências Biomédicas, Universidade de São Paulo, 2009.

A movimentação dentária ortodôntica ocorre através de dois processos, nos quais o osso alveolar é reabsorvido nas áreas de pressão, enquanto que novo osso é formado na área de tensão. Acreditava-se que a reparação do osso alveolar durante a movimentação ortodôntica só ocorria após a diminuição da carga aplicada. No entanto, estudos recentes demonstraram a reparação do osso alveolar e ausência de reabsorção radicular com a aplicação de uma força contínua. Entretanto, é possível que ocorra reabsorções radiculares com tempos maiores de aplicação de força. Osteopontina (OPN) é uma proteína não colágena da matriz do tecido ósseo com importante papel na remodelação óssea fisiológica e induzida. Com o intuito de analisar as reações no periodonto de sustentação e a presença e distribuição de OPN nesses eventos, uma força contínua de $15 \mathrm{cN}$ foi aplicada aos primeiros molares superiores de ratos machos Wistar de 2,5 meses na direção vestibular por $12 d(n=8)$, $15 d(n=8)$, 18d $(n=8)$. Como controle, 6 animais não tiveram seus molares movimentados. As maxilas foram fixadas em formaldeído a $2,5 \%+2 \%$ glutaraldeído tamponado com cacodilato de sódio $0,1 \mathrm{M}$ (morfologia e imunohistoquímica) ou formaldeído a $4 \%+0,1 \%$ glutaraldeído tamponado com cacodilato de sódio $0,1 \mathrm{M}$ (imunocitoquímica) sob irradiação de microondas e descalcificadas em EDTA 4,13\%. Depois foram processadas para análise ultra-estrutural morfológica, imunocitoquímica para OPN e imunohistoquímica para fosfatase ácido resistente ao tartarato (TRAP) para identificação de células clásticas. No tempo inicial do estudo não foram encontradas reabsorções radiculares, o cemento apresentou-se com sua superfície lisa e contínua. Nos tempos intermediários e finais, no entanto, reabsorções radiculares estavam presentes e aumentavam sua severidade com o tempo. Além disso, foi observado sinal de reparação do cemento. A expressão de OPN apresentouse aumentada na superfície alveolar e radicular.

Palavras-chave: Movimento ortodôntico. Remodelação óssea. Osso alveolar. Osteopontina. Reabsorção radicular. Periodonto. 


\begin{abstract}
D'ANDREA-MATEUS, N. Ultrastructural and immunocytochemical study of periodontal reactions to orthodontic continuous force in rat molars buccally applied for long periods. 102f. Dissertation. São Paulo; Instituto de Ciências Biomédicas, Universidade de São Paulo, 2009.

Orthodontic tooth movement takes place by two coupling processes in which alveolar bone is resorbed at pressure regions pressure; whereas new bone is formed at the regions of tension. It is usually believed that repair in alveolar bone during orthodontic movement occurs after decreasing of force. However, we have recently observed signs of repair in alveolar bone submitted to continuous orthodontic force. Osteopontin (OPN) is one of the major noncollagenous proteins of bone matrix with multifunctional properties and it is believed to play a key role in physiological remodelation and mechanical stress. In order to test periodontal reactions and the presence and distribuition of OPN, a continuous $15 \mathrm{cN}$ force was applied in a buccal direction to upper first molars from two and half months old male Wistar rats for $12 d(n=8), 15 d(n=8), 18 d$ $(n=8)$. As a control, other six rats did not have their molars moved. Maxillae were fixed under microwave irradiation and decalcified in EDTA. Specimens were processed for ultrastructural analysis, imunocytochemistry for OPN and for tartarate-resistant acid phosphatase (TRAP) histochemistry. Ultrastructural analysis reveals root resorption at $15 \mathrm{~d}$ and $18 \mathrm{~d}$. Deep lacunae appeared in some regions of the pressure area after 18 days, most of them reaching the underlying root dentine. Signs of repair were detected concomitant with tissue damage and resorption of the root surfaces. Besides, at all times studied, OPN was present recovering alveolar bone and root surface, and it was overexpressed.
\end{abstract}

Key Words: Orthodontic movement. Bone remodelation. Alveolar bone. Osteopontin. Root resorption. Periodontium. 


\section{SUMÁRIO}

\section{RESUMO}

\section{ABSTRACT}

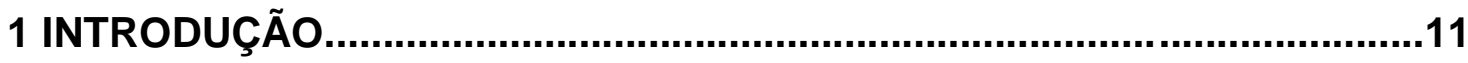

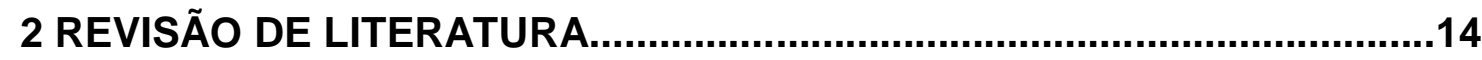

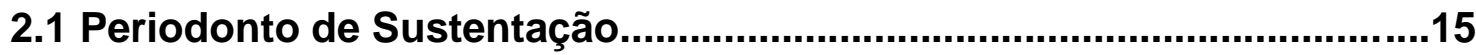

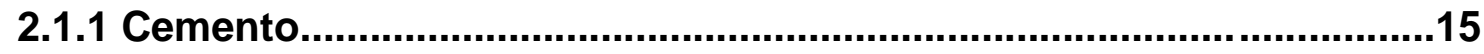

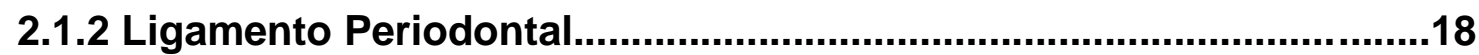

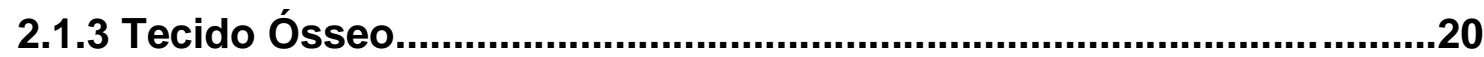

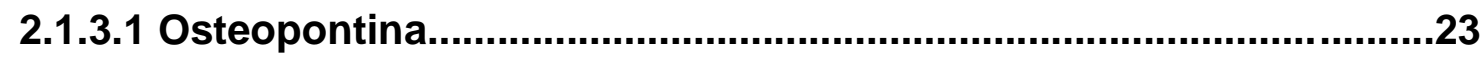

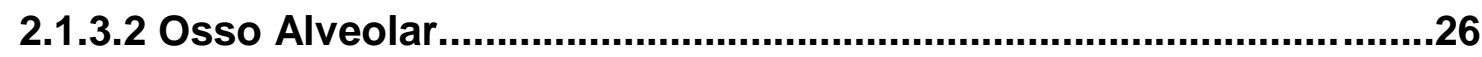

2.2 Reações Teciduais Frente à Movimentação Ortodôntica......................27

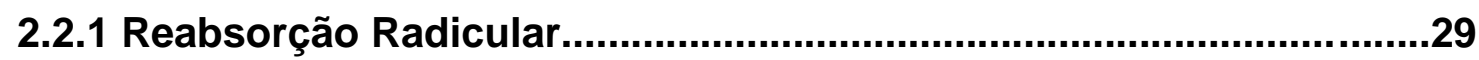

2.2.2 Magnitude de Força...............................................................................

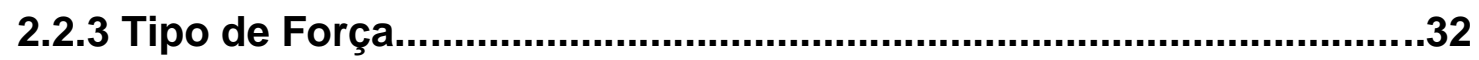

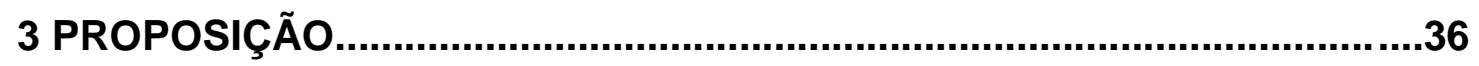

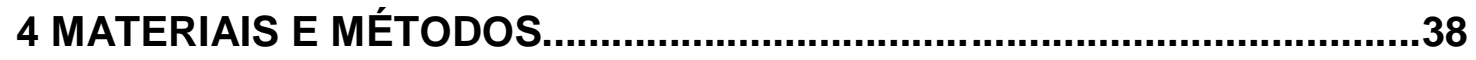

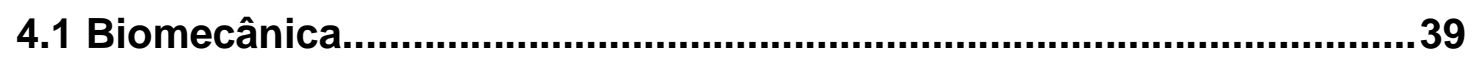

4.2 Tempos de aplicação de força contínua e obtenção dos espécimes.43

4.3 Microscopia Eletrônica de Transmissão: Morfologia.............................43

4.4 Microscopia de Luz: Método Histoquímico do TRAP.............................44

4.5 Imunocitoquímica pós inclusão com ouro coloidal...............................45

5 RESULTADOS

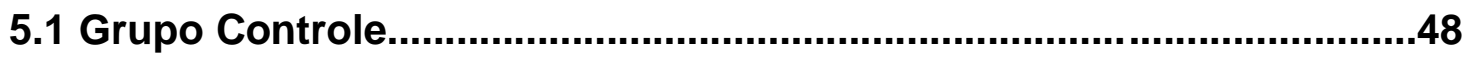

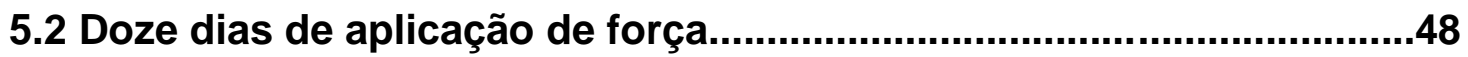

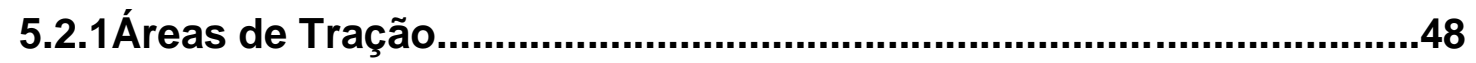




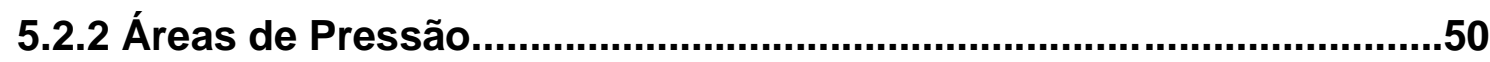

5.3. Quinze dias de aplicação de força......................................................58

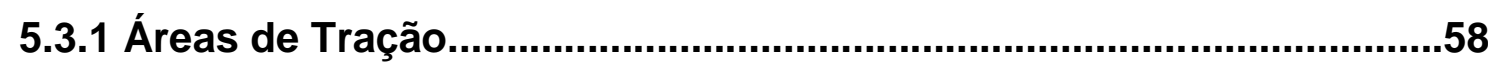

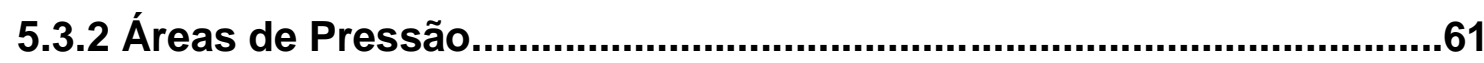

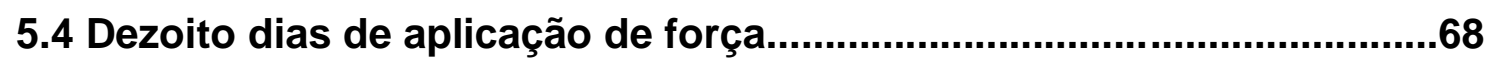

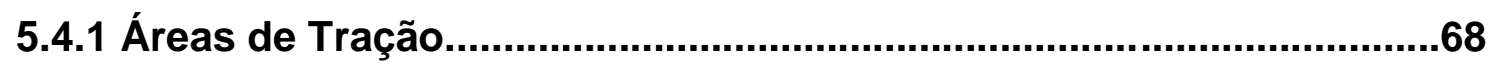

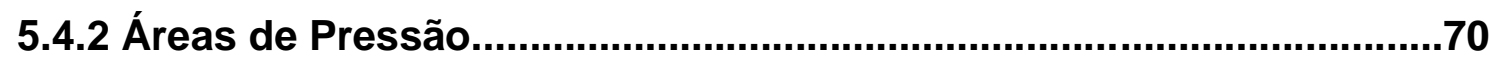

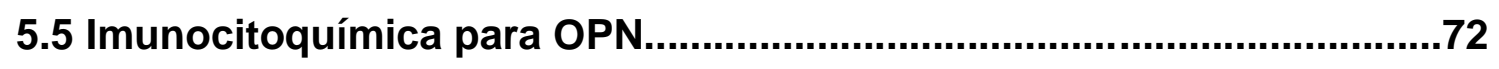

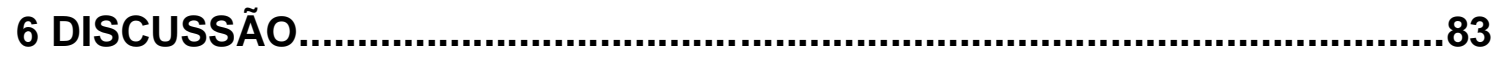

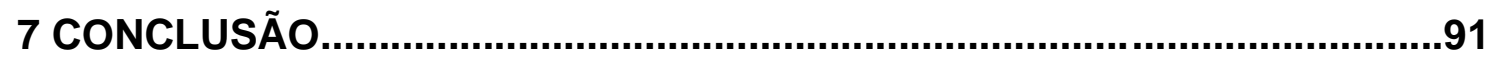

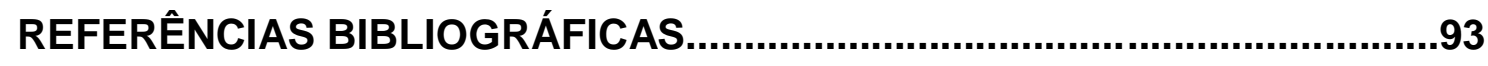


1 INTRODUÇÃO 
O conhecimento das reações teciduais é essencial e muito importante para o entendimento da movimentação dentária ortodôntica e para 0 aperfeiçoamento dos tratamentos ortodônticos. Com esse intuito, muitos estudos vêm sendo realizados para desmistificar esse aspecto fundamental.

A movimentação dentária ortodôntica ocorre através de dois processos, nos quais o osso alveolar é reabsorvido nas áreas de pressão enquanto novo osso é formado nas áreas de tensão. Isso é possível porque o osso é um tecido dinâmico que está em constante remodelação. Esse é um processo complexo, que requer interações entre diferentes tipos celulares (osteoclastos e osteoblastos) que são regulados por fatores bioquímicos ou fatores mecânicos (por exemplo, a movimentação ortodôntica). As repostas no osso alveolar são mais intensas do que as que ocorrem no cemento (TEN CATE, 1998).

Acreditava-se que a reparação tecidual do periodonto durante a movimentação ortodôntica ocorresse somente após a diminuição da magnitude da força aplicada (BRUDVICK e RYGH, 1995), sendo assim eram utilizadas forças intermitentes, cuja força vai diminuindo gradualmente, e, portanto são necessárias reativações constantes. No entanto, com o desenvolvimento dos fios de níquel-titânio superelástico (NiTi) na ultima década foi possível a aplicação de forças contínuas durante a movimentação ortodôntica. Alguns estudos foram realizados, e analisaram as respostas do periodonto de sustentação frente a tais estímulos. Estudos em humanos, que utilizaram forças ortodônticas contínuas em pré-molares, avaliando a ultra-estrutura do cemento e ligamento periodontal sob estímulos ortodônticos de intrusão (FALTIN et al., 1998, 2001) e torque (CASA et al., 2001) observaram sinais de reparação no cemento previamente reabsorvido. Recentemente, um estudo em animais, utilizando força contínua, demonstrou que a reabsorção coexiste com a formação óssea no lado de pressão, mesmo com a manutenção da força (BONAFE-OLIVEIRA et al., 2003).

Osteopontina (OPN) é uma das proteínas não colágenas mais abundantes da matriz dos tecidos mineralizados. Quanto a sua expressão gênica há controvérsias, alguns autores sugerem que esta proteína seja 
produzida por osteoblastos (HIRAKAWA et al.; 1994, WEINREB et al., 1990), outros sugerem que ela é produzida por osteoclastos ( MEERY et al., 1993; DODDS et al., 1993). A OPN tem um papel importante no processo de remodelação óssea fisiológica (DENHARDT e NODA, 1998) participando nas fases de reabsorção e de formação. Alguns estudos sugerem que a expressão de OPN encontra-se aumentada na remodelação óssea frente a stress mecânico (TERAl et al., 1999; FUJIHARA et al., 2006; MORINOBU et al., 2003; CHUNG et al., 2008). No cemento, apesar de a OPN estar presente, poucos trabalhos avaliaram a sua função e distribuição. Há evidências de que a OPN tem um papel importante no cemento, uma vez que a ausência desta proteína leva a uma diminuição do número de osteoclastos e com isso causa uma diminuição da reabsorção radicular quando um stress mecânico é causado ao tecido ósseo (CHUNG et al., 2008). No processo de reparação do cemento, Jaeger et al. (2008) encontraram OPN no cemento recém sintetizado.

Bonafe-Oliveira (2006) em um estudo sobre reações teciduais frente a movimentação ortodôntica utilizando força contínua, mostrou que a reabsorção coexiste com a formação óssea no lado de pressão, mesmo com a manutenção da força. Nas áreas de pressão foram encontradas numerosas concavidades contendo osteoclastos e osteoblastos sobre as lacunas previamente reabsorvidas. Áreas de hialinização restringiam-se ao ligamento periodontal e eram mais evidentes no $10^{\circ}$ dia. Em nenhum momento a hialinização causou danos irreversíveis ao periodonto de sustentação. Não foi observada reabsorções radiculares quando força contínua foi aplicada por 10 dias em molares de ratos. No entanto, é possível que ocorra reabsorção radicular após um período maior de aplicação de força. Esse trabalho também determinou a distribuição da proteína não colágena osteopontina nas superfícies ósseas, principalmente nas áreas de pressão, a qual depositava-se em grande quantidade, formando espessas faixas. $O$ presente trabalho tem como objetivo o estudo das respostas do periodonto de sustentação aplicando o modelo descrito anteriormente em ratos (BONAFE-OLIVEIRA et al., 2003), analisando tempos entre 10 e 18 dias, e examinar também a distribuição da proteína osteopontina através de imunocitoquímica de alta resolução. 
2 REVISÃO DE LITERATURA 
Antes de abordar os aspectos diretamente relacionados com o presente estudo será feita uma breve revisão sobre as características dos tecidos que constituem o periodonto de sustentação bem como dos principais conceitos referentes à movimentação dentária ortodôntica.

\subsection{Periodonto de Sustentação}

A movimentação dentária ocorre devido à participação direta do periodonto de sustentação, que é constituído pelo cemento, ligamento periodontal e osso alveolar. Os componentes do periodonto de sustentação possuem a mesma origem embriológica, a partir de células ectomesenquimais do folículo dentário. Os três tecidos formam-se simultaneamente e sua associação, uma vez formados, é responsável pela manutenção do dente em seu respectivo alvéolo.

\subsubsection{Cemento}

É um tecido conjuntivo mineralizado que recobre a dentina radicular e no qual se inserem fibras colágenas do ligamento periodontal. O cemento se desenvolve a partir do folículo dentário, uma estrutura que não faz parte do germe dentário propriamente dito (órgão do esmalte e papila dentária), não sendo, portanto, uma estrutura dentária, apesar de ser depositado sobre a dentina da raiz e de aderir-se firmemente a esse tecido.

O cemento apresenta muitas semelhanças com o tecido ósseo: possui aproximadamente $60 \%$ de mineral sob a forma de hidroxiapatita, sua matriz orgânica é constituída por colágeno do tipo I, o tipo III também é identificado, porém em menores proporções (TENÓRIO et al., 1993) e proteínas não colágenas, como a osteopontina, sialoproteína óssea, fibronectina, vitronectina (SAYGIN et al.,2000), osteonectina, osteocalcina e proteína de adesão 
cementária (GRZESIK e NARAYANAN, 2002); suas células cementoblastos e cementócitos, são similares aos osteoblastos e osteócitos, respectivamente.

Em contraste, o cemento é um tecido sem inervação e avascular (THILANDER et al., 2005) que depende do ligamento periodontal para sua nutrição. Ele não sofre remodelação, embora seja passível de reabsorção e neoformação.

A espessura do cemento varia segundo a região. Assim sendo é muito fino no terço cervical da raiz, possuindo cerca de 30-50 $\mu \mathrm{m}$, aumentando gradualmente em direção ao ápice, alcançando 180-200 $\mu \mathrm{m}$. O cemento pode ser dividido em três tipos diferentes: cemento acelular de fibras extrínsecas, cemento celular de fibras mistas e cemento celular de fibras intrínsecas.

No terço cervical o cemento é acelular, possui uma matriz fibrosa, constituída por feixes de fibras colágenas, exclusivamente do tipo I, produzidas pelos fibroblastos do ligamento periodontal durante o desenvolvimento do periodonto de inserção. Essas porções de fibras colágenas do ligamento periodontal que ficam inseridas no cemento são denominadas fibras de Sharpey e sofrem um processo muito uniforme de mineralização. Tênues linhas incrementais podem ser observadas, devido à existência de períodos de repouso durante a formação deste tipo de cemento, após as quais a direção das fibras extrínsecas pode mudar. Na borda do cemento mineralizado estão presentes fibroblastos e não cementoblastos como ocorre nas demais regiões. (BOSSHARDT e SCHROEDER, 1996).

A partir do terço médio da raiz e nas áreas de furcação dos dentes bi ou tri- radiculares, o cemento é do tipo celular de fibras mistas, apresentando maior espessura que o acelular. Assim sendo, além da presença de lacunas contendo cementócitos e de numerosos canalículos percorridos pelos prolongamentos dessas células sua matriz orgânica é constituída por fibrilas colágenas produzidas tanto pelos cementoblastos quanto por fibroblastos do ligamento periodontal durante a formação do periodonto de inserção, daí sua denominação de cemento de fibras mistas. Outra característica que o diferencia do anterior é a incompleta mineralização das fibras de Sharpey. 
O cemento celular de fibras intrínsecas não é formado durante 0 processo de cementogênese. $O$ fato de os três tecidos que constituem $O$ periodonto de inserção se desenvolverem simultaneamente, condiciona a presença de fibras extrínsecas, em maior ou menor proporção no cemento formado durante a cementogênese. Por esse motivo, a formação de um tipo de cemento constituído apenas pelo produto dos cementoblastos só é possível quando os dois tecidos, cemento e ligamento, já estão formados. Isso quer dizer que o cemento celular de fibras intrínsecas é originado só em casos de reparação, geralmente após reabsorção cementária (KATCHBURIAN e ARANA-CHAVEZ, 2004).

$\mathrm{Na}$ borda do cemento mineralizado existe uma camada de matriz orgânica não mineralizada chamada cementóide, junta a qual estão presentes cementoblastos. Os cementoblastos são as células que sintetizam a matriz orgânica de natureza intrínseca do cemento. Os cementoblastos ativos apresentam características comuns às células que sintetizam e secretam proteínas.

Quando o cemento está formado, os cementoblastos ficam justapostos ao cemetóide, porém em estado de repouso, apresentam forma achatada com quantidade reduzida de organelas relacionadas à síntese e secreção protéica. Estes cementoblastos podem retomar sua atividade de síntese e secreção de matriz orgânica, passando, portanto, a desenvolver essas organelas e aumentando conseqüentemente o seu volume.

Os cementoblastos que ficaram aprisionados na matriz do cemento durante sua formação são conhecidos como cementócitos, células muito semelhantes aos osteócitos. Estas células possuem numerosos prolongamentos que estabelecem comunicação com os prolongamentos das células vizinhas e cementoblastos através de canalículos. Os cementócitos desenvolvem pouca atividade metabólica e por isso, possuem poucas organelas em seu citoplasma. Dependem da difusão de nutrientes a partir do ligamento periodontal, portanto a maioria dos seus prolongamentos dirige-se para a superfície externa cementária. 


\subsubsection{Ligamento Periodontal}

O ligamento periodontal é um tecido conjuntivo frouxo, ricamente vascularizado e celular que circunda as raízes dos dentes e une o cemento ao osso alveolar. A presença do ligamento periodontal é essencial para a mobilidade do dente, sendo que ela é em grande parte determinada pela largura, altura e qualidade do ligamento periodontal. Sua largura diminui com a idade e varia de 0,15 a $0,38 \mathrm{~mm}$ no seu longo eixo, sendo que sua porção mais estreita situa-se no terço médio radicular (NANCI e BOSSHARDT, 2006).

O ligamento periodontal possui diferentes tipos celulares. São encontrados fibroblastos, células clásticas, células indiferenciadas e grupos de células epiteliais remanescentes, denominados restos epiteliais de Malassez (BEERTSEN et al., 1997), além de osteoblastos, cementoblastos na interface com o osso alveolar e cemento, respectivamente. Por serem as células responsáveis pela formação do colágeno, o fibroblasto é predominante dentre os tipos celulares encontrados. Essas células possuem retículo endoplasmático rugoso e complexo de Golgi muito desenvolvido, bem como numerosos grânulos de secreção. São células alongadas com extensos processos citoplasmáticos, possuem citoesqueleto bem desenvolvido e ficam alinhados com os feixes de fibras colágenas (NANCl e BOSSHARDT, 2006). Além dessas organelas, os fibroblastos apresentam vacúolos citoplasmáticos contendo fragmentos de fibrilas colágenas e enzimas proteolíticas como fosfatase ácida, característica essa que explica a renovação do colágeno ser realizada por esse tipo celular, tanto do ponto de vista da sua formação quanto da sua degradação. Contudo, o ligamento periodontal constitui o tecido conjuntivo do organismo onde ocorre a maior renovação de colágeno (CARNEIRO e FAVA DE MORAES, 1965), uma vez que as forças que incidem sobre o ligamento são multidirecionais, tendo componentes verticais e horizontais (THILANDER et al.,2005).

A matriz do ligamento periodontal é constituída por proteínas fibrosas e não fibrosas e por uma substância fundamental. 
O colágeno constitui a principal proteína fibrosa do ligamento periodontal, correspondendo a $50 \%$ do seu peso seco. Os colágenos tipo I e III são os mais abundantes (EMBERY, 1990), no entanto outros tipos de colágeno, como tipo III, V, VI, XII também são encontrados (BEERTSEN, 1997), além de fibras oxitalânicas e eulanínicas (BEERTSEN et al., 1997).

Os feixes de fibras colágenas que se inserem do cemento ao osso alveolar atravessando o ligamento periodontal constituem as fibras principais. A porção embutida do feixe de fibras é denominada fibras de Sharpey, sendo que no cemento essas fibras têm maior diâmetro e são mais densamente agrupadas do que no osso alveolar. Além das fibras principais, existem as fibras secundárias, que não se inserem ao osso nem ao cemento, tendo uma orientação de forma aleatória entre as fibras principais e ao redor de vasos sanguíneos e nervos.

As fibras oxitalânicas que são estruturalmente semelhantes às fibras elásticas em desenvolvimento constituem cerca de $3 \%$ das fibras do ligamento periodontal. Elas se dispõem paralelas à superfície da raiz (EMBERY, 1990), estendendo-se à superfície dos vasos sanguíneos e mantendo estreita relação com os mesmos (BERKOVITZ, 2004).

Embora o ligamento periodontal seja rico em colágeno, cerca de $60 \%$ do volume total é composto pela substância fundamental, que é constituída principalmente por proteoglicanos, glicosaminoglicanos, glicoproteínas e alguns lipídeos associados, além de grande quantidade de água, a qual se acredita ter um papel na resistência e suporte das forças aplicadas sobre o dente no periodonto (KATCHBURIAN e ARANA-CHAVEZ, 2004). A matriz tem sido relatada como responsável pelo controle da formação de fibrilas colágenas e sua orientação, além de agir como inibidora da calcificação do ligamento periodontal (BERKOVITZ, 2004).

Além da função de suporte, absorção de forças e do seu papel sensorial, - ligamento periodontal atua como remodelador, fornecendo células capazes de formar e reabsorver todos os tecidos que formam, ou seja, osso, cemento e ligamento. Assim, células ectomesenquimais indiferenciadas podem se diferenciar em osteoblastos, cementoblastos ou fibroblastos. As células 
clásticas reabsorvem tanto o tecido ósseo quanto cemento, sendo que a fagocitose do colágeno é realizada pela célula que o produz, fibroblasto (LEKIC e MCCULLOCH, 1996).

\subsubsection{Tecido Ósseo}

O tecido ósseo é um tecido mineralizado de natureza conjuntiva. É o principal constituinte do esqueleto, serve de suporte para as partes moles e protege os órgãos vitais, aloja e protege a medula óssea e proporciona apoio aos músculos esqueléticos. Além dessas funções, o tecido ósseo funciona como depósito de cálcio e fosfato armazenando-os ou liberando-os de maneira controlada.

O tecido ósseo é constituído por uma fase mineral e uma fase orgânica, além das células. A parte mineral representa $65 \%$ do peso do osso, e é constituída por fosfato de cálcio sob a forma de cristais de hidroxiapatita. A parte orgânica representa $20 \%$ do peso e água $15 \%$.

No tecido ósseo três tipos celulares podem ser encontrados: os osteoblastos que são os responsáveis pela formação do tecido ósseo, os osteócitos que são os osteoblastos que ficam aprisionados durante a mineralização da matriz e os osteoclastos que reabsorvem o osso.

Os osteoblastos são as células mononucleares, de origem mesenquimal, que sintetizam a parte orgânica (colágeno tipo I, proteoglicanas e glicoproteínas) da matriz óssea, portanto apresentam características de células que sintetizam e secretam proteínas, ou seja, abundante retículo endoplasmático rugoso, complexo de Golgi bem desenvolvido e grande quantidade de vesículas de secreção. Quando a formação de tecido ósseo diminui, os osteoblastos tornam-se achatados, inativos e são denominados células de revestimento ósseo ou bone lining cells (HIRASHITA, 1976). No entanto, os osteoblastos podem voltar a sintetizar e secretar matriz quando houver necessidade de formação de novo tecido ósseo. 
Durante o processo de mineralização do osteóide, alguns osteoblastos ficam aprisionados na matriz. Essas células são denominadas osteócitos, e são as células mais abundantes do tecido ósseo (FRANZ-ODENDAAL et al., 2006). Os osteócitos são células achatadas que apresentam pequena quantidade de retículo endoplasmático rugoso e aparelho de Golgi, ou seja, possuem uma atividade metabólica pobre. No entanto, a presença de osteócitos é indispensável para a manutenção da homeostase óssea (KATCHBURIAN e ARANA-CHAVEZ, 2004). Os osteócitos ficam contidos em lacunas existentes no interior da matriz óssea mineralizada. Entretanto eles não ficam isolados; uma rede de canalículos contendo prolongamentos dos osteócitos interconecta as lacunas permitindo a difusão de nutrientes e de pequenas moléculas. Esses canalículos mantêm contato através de junções comunicantes ("gap junctions") com outros osteócitos, células de revestimento ósseo e com osteoblastos.

Os osteoclastos são células móveis, multinucleadas, formadas a partir de células mononucleares derivadas do tecido hematopoiético que sob estímulos específicos se fusionam e aderem ao tecido ósseo (Lerner, 2001) sendo responsáveis pela reabsorção do tecido ósseo. Os osteoclastos se formam próximos ao tecido ósseo, razão pela qual osteoclastos multinucleados nunca aparecem na circulação sangüínea (Lerner, 2001). Existem vários fatores que atuam positivamente ou negativamente na formação e atividade dos osteoclastos. Fatores de crescimento estimulam a proliferação e previnem apoptose de precursores de osteoclastos. O RANKL é um fator presente na superfície dos osteoblastos que ativa a formação de osteoclastos. Já a osteoprotegerina liga-se ao RANKL bloqueando-o (ROODMAN, 2006; ARANACHAVEZ e BRADASCHIA-CORREA, 2009).

Adjacente à superfície do osso, a membrana celular dos osteoclastos emite uma grande quantidade de profundas invaginações que formam uma borda em escova ou borda franjada. Na periferia da borda em escova, a membrana plasmática fica justaposta à superfície do osso, sendo a borda em escova rodeada por uma área citoplasmática desprovida de organelas celulares, preenchida com proteínas fibrilares contráteis, denominada zona clara ou "selante". Esta não apenas une o osteoclasto à superfície 
mineralizada, mas também isola o microambiente entre ele e a superfície do osso, tornando assim um microambiente favorável à reabsorção óssea (DELAISSE et al., 2003). A borda em escova é considerada a região mais ativa do osteoclasto na sua função reabsortiva. A superfície que está sendo reabsorvida é chamada de lacuna de Howship. Um osteoclasto pode apresentar várias regiões correspondentes à borda em escova e a zona clara, caso esteja aposto ao osso em mais de um ponto.

O único processo conhecido para a dissolução de mineral é a acidificação (MULARI et al., 2003). No microambiente criado pela borda em escova, zona clara e matriz mineralizada, ocorre a acidificação do meio através da ação de uma bomba de prótons ATPase tipo V (vacuolar) (MULARI et al., 2003) iniciando assim a desmineralização da matriz inorgânica. A degradação da matriz orgânica ocorre pela liberação aminoácidos produzidos pela ação de enzimas liberadas, tais como catepsina B (DELAISSE et al., 2003), catepsina $\mathrm{K}$ (MULARI et al., 2003) e um tipo especial de fosfatase ácida, a fosfatase ácida resistente ao tartarato (TRAP). Com isso, a atividade do osteoclasto pode ser determinada pela reação imunohistoquímica desta enzima lisosomal.

A matriz extracelular do tecido ósseo é composta pela matriz orgânica que contém $85 \%$ de colágeno do tipo I, $5 \%$ de colágeno do tipo III e $\mathrm{V}$ e os outros $10 \%$ é composto de proteínas não colégenas como as fosfoproteínas, osteocalcina, osteonectina, osteopontina (OPN), sialoproteína óssea (BSP), proteoglicanas/glicosaminoglicanas (decorina, biglicana, osteoaderina) e proteínas séricas (KATCHBURIAN e ARANA-CHAVEZ, 2004).

O osso é um tecido dinâmico que está em constante remodelação, mesmo após o crescimento ter cessado (HILL, 1998). A remodelação óssea é um processo no qual ocorre reabsorção e formação óssea simultaneamente. Esse processo pode ser dividido didaticamente em fases: I) Ativação, onde ocorre o recrutamento de células precursoras de osteoclastos, diferenciação em osteoclastos, migração e adesão de osteoclastos à superfície óssea, II) Reabsorção, momento em que de fato ocorre a reabsorção da matriz mineralizada pelos osteoclastos, III) Reversão, ocorre o afastamento dos osteoclastos da superfície mineralizada; recrutamento de precurssores de 
osteoblastos, proliferação, migração e diferenciação dos osteoblastos, IV) Formação, início de secreção de proteínas não colágenas sobre a superfície óssea previamente reabsorvida, deposição de nova matriz de tecido ósseo sobre a camada de proteínas não colágenas sintetizada anteriormente (McKEE e NANCl, 1995). Este é um processo complexo que requer a interação de diferentes tipos celulares. $\mathrm{O}$ osso se remodela para responder e se adaptar a estresses mecânicos, por exemplo, durante a movimentação ortodôntica (HILL, 1998), para se adaptar a novas situações fisiológicas ou patológicas, ou quando o osso precisa modificar sua forma ou estrutura (KATCHBURIAN e ARANA-CHAVEZ, 2004).

\subsubsection{Osteopontina}

A osteopontina (OPN) é uma das proteínas não colágenas mais abundantes da matriz dos tecidos mineralizados. É uma proteína altamente glicosilada e fosforilada, que contém um domínio ácido poliaspártico, através do qual a proteína pode se ligar a hidroxiapatita e íons cálcio. Além disso, a OPN contém inúmeros domínios de adesão celular incluindo uma seqüência arginina-glicina-aspartato (RGD), uma região com afinidade para alguns receptores celulares, incluindo $\alpha_{v} \beta_{3}, \alpha_{v} \beta_{1}$ e $\alpha_{v} \beta_{5}$ (SODEK et al.,2000) através do qual é possível mediar adesões celulares.

A OPN está presente em muitos tecidos mineralizados e moles como o rim, cérebro (SODEK et al., 2000), fluidos corporais tais como saliva, leite e sangue (GIACHELLI e STEIZ, 2000), tumores (GIACHELLI e STEIZ, 2000; SODEK et al., 2000), cartilagem calcificada e na placa ateroesclerótica calcificada (McKEE e NANCl, 1996b). Nos tecido mineralizados, ela é encontrada no osso, cemento e dentina (McKEE e NANCl, 1996a). Fora da matriz dos tecidos mineralizados, a OPN é pouco encontrada em condições saudáveis, sua maior distribuição é encontrada sob condições patológicas, estando aumentada em processos inflamatórios e remodelação óssea (GIACHELLI e STEIZ, 2000). Além disso, a OPN parece fazer parte da 
cicatrização, pois tem sido implicada no recrutamento e estimulação de macrófagos e linfócitos em resposta a infecções não específicas (McKEE e NANCI, 1996c).

O osso contém grande quantidade de OPN, e elas são detectadas em regiões específicas deste tecido. A OPN pode ser observada entre os espaços fibrilares da matriz óssea aparecendo como pequenos acúmulos (McKEE e $\mathrm{NANCl}, 1996 a, b)$ ). Além disso, também são encontradas em interfaces teciduais incluindo as linhas cimentantes e laminae limitans (McKEE e NANCl, 1996a, b). Linha cimentante é uma interface intensamente corada, quando examinada ao microscópio de luz, e elétron-opaca, quando analisada ao microscópio eletrônico de transmissão, entre duas matrizes mineralizadas. Ela pode ser do tipo reversa, quando é formada previamente a áreas reabsorvidas ou incremental que é formada em áreas onde a aposição óssea foi interrompida. Laminae limitans também é uma estrutura delgada elétron-opaca em microscopia eletrônica, encontrada entre célula- matriz, ou seja, na periferia do osso e do cemento, com suas células ósseas e cementárias respectivamente. Tais regiões compreendem a periferia da lacuna do osteócito (ou cementócito), dos canalículos e superfícies ósseas adjacentes às células de revestimento ósseo (McKEE e NANCl, 1996a, b).

A OPN também está presente em grande quantidade na matriz do cemento (BOSSHARDT et al., 1998). Esta proteína acumula-se entre as fibrilas colágenas na junção cemento-dentinária contribuindo para reforçar a união entre estes dois tecidos. (McKEE e NANCl, 1996a,b; BOSSHARDT et al.,1998).

A OPN tem um papel importante no processo de remodelação óssea fisiológica (DENHARDT e NODA, 1998) participando nas fases de reabsorção e de formação.

Alguns estudos sugerem que durante o processo de remodelação óssea fisiológica, na fase de reabsorção, a OPN participa mediando adesão de osteoclastos sobre o tecido ósseo (REINHOLT et al.,1990; DODDS et al., 1995) recoberto pela laminae limitans. Tal estrutura serviria como substrato para adesão de osteoclastos e conseqüentemente para o selamento dessa célula 
sobre a matriz mineralizada. Esta adesão seria realizada através de uma ligação da seqüencia RGD da molécula de OPN presente na laminae limitans com a membrana plasmática da zona clara dos osteoclastos, a qual possui a integrina $\alpha_{v} \beta_{3}$,que tem afinidade à OPN (SODEK et al., 2000).

$\mathrm{Na}$ fase de neoformação óssea, a OPN é secretada pelos préósteoblastos e está presente nas linhas cimentantes. Esta OPN serve como um leito para a formação de uma matriz óssea e sua mineralização, e possivelmente para a adesão de osteoblastos nessa região. E finalmente, ela agiria como uma "cola biológica" promovendo a adesão do novo tecido ósseo com o tecido antigo (McKEE e NANCl, 1995).

O papel da OPN na remodelação óssea fisiológica vem sendo bastante estudado, no entanto, a remodelação óssea pode ser induzida como é o caso da movimentação ortodôntica, quando uma força é aplicada sobre os dentes e esta é transmitida aos tecidos adjacentes (ligamento periodontal e osso alveolar) promovendo a remodelação óssea induzida. Estudos demonstram que a expressão de OPN está aumentada durante a remodelação óssea induzida por stress mecânico (TERAl et al., 1999;FUJIHARA et al., 2006; MORINOBU et al., 2003 ;CHUNG et al., 2008). A expressão de OPN é aumentada nos osteócitos, osteoblastos e células de revestimento ósseo, além disso, a OPN tem um papel na diferenciação, proliferação e quimiotaxia de osteoclastos durante o processo de remodelação óssea induzida (TERAl et al., 1999).

No cemento, apesar de a OPN estar presente, poucos trabalhos avaliaram a sua função e distribuição. Há evidências de que a OPN tem um papel importante no cemento, uma vez que a ausência desta proteína leva a uma diminuição do número de osteoclastos e com isso causa uma diminuição da reabsorção radicular quando um stress mecânico é causado ao tecido ósseo (CHUNG et al., 2008). No processo de reparação do cemento, Jaeger et al., 2008 encontraram OPN no cemento recém sintetizado. 


\subsubsection{Osso Alveolar}

O osso alveolar é a parte da maxila e da mandíbula que constitui junto com o ligamento periodontal e cemento o periodonto de sustentação. Ele possui as mesmas características de um tecido ósseo, porém com algumas peculiaridades.

O osso alveolar forma-se devido ao desenvolvimento do dente. Logo após o início da odontogenêse radicular começa a formação do periodonto de inserção, portanto, é simultânea à formação dos elementos do periodonto de sustentação. É extremamente dinâmico, respondendo rapidamente as demandas funcionais e a estímulos externos. A habilidade de remodelação do osso alveolar pode ser vista durante a movimentação ortodôntica.

$\mathrm{Na}$ parte mais profunda do osso alveolar existem alguns sistemas de Havers, enquanto sua maior parte, voltada para o ligamento, é constituída por lamelas paralelas. Em geral a estrutura básica do osso alveolar é semelhante ao tecido ósseo de outras regiões do organismo, com numerosos osteócitos alojados em lacunas e comunicados por meio de prolongamentos nos canalículos que percorrem a matriz mineralizada. No entanto, o osso alveolar possui algumas diferenças em relação ao tecido ósseo. O osso alveolar possui feixes de fibras colágenas inseridas perpendicularmente à sua superfície que são as fibras de Sharpey, que lhe conferem um aspecto fasciculado (por essa razão é também chamado de osso fasciculado) (KATCHBURIAN e ARANACHAVEZ, 2004). As fibras do osso alveolar propriamente ditas - intrínsecassão perpendiculares às fibras de Sharpey - extrínsecas. A superfície do osso alveolar voltada para o ligamento periodontal está recoberta por uma camada de osteoblastos ou células de revestimento ósseo justapostas. Entre duas ou mais células existem túneis pelos quais passam os feixes de fibras principais que ficam em íntimo contato com a membrana das células. 


\subsection{Reações Teciduais Frente à Movimentação Ortodôntica}

As respostas biológicas decorrentes da movimentação ortodôntica envolvem reações teciduais nos tecidos periodontais, especialmente no periodonto de sustentação. Muitos estudos têm sido realizados avaliando essas reações, estabelecendo-se que, em geral, a movimentação ortodôntica ocorre através de dois processos no osso alveolar: reabsorção nas áreas de pressão e formação nas áreas de tração (REITAN, 1951, 1960). Isso é possível porque o osso é um tecido dinâmico que está em constante remodelação. Esse é um processo complexo, que requer interações entre diferentes tipos celulares (osteoclastos e osteoblastos) que são regulados por fatores bioquímicos ou fatores mecânicos (por exemplo, a movimentação ortodôntica). Vários estudos histológicos analisando essa movimentação através da aplicação de forças intermitentes, nas quais a intensidade de força declina gradativamente sendo necessárias ativações periódicas na biomecânica, resultaram nos conceitos clássicos sobre reações teciduais frente à movimentação ortodôntica (RYGH, 1973, 1976).

Em decorrência desses estudos sabe-se que nas áreas de pressão, ocorre aumento do número de osteoclastos e conseqüentemente reabsorção óssea. No ligamento periodontal dessas áreas ocorrem alterações na vascularização e fluxo sangüíneo (RYGH, 1972a), além de picnose dos núcleos dos fibroblastos, desorganização das fibras colágenas e hialinização (RYGH, 1972b, 1973).

Hialinização é um termo que define uma área necrótica localizada no ligamento periodontal, isenta de elementos celulares e outras estruturas parecendo ser um fator limitante do movimento dentário (RYGH, 1973), podendo envolver lesões permanentes como reabsorções radiculares (RYGH, 1974). A maioria dos estudos indica que a hialinização do ligamento periodontal durante a fase inicial do tratamento ortodôntico é quase inevitável (REITAN, 1957; RYGH, 1995).

$\mathrm{Na}$ área hialinizada, não há o recrutamento dos precursores de osteoclastos, e com isso não há fusão e ativação dos osteoclastos, ficando 
"parado" o movimento ortodôntico até que o tecido seja eliminado (RYGH, 1995). Portanto, a formação de extensas áreas hialinizadas pode causar um atraso no tratamento ortodôntico (REITAN, 1962). Uma grande variedade de células pode estar envolvida com 0 processo de eliminação das áreas hialinizadas, como macrófagos, células mononucleadas e osteoclastos (BRUDVIK e RYGH, 1993a,b).

O processo de reparação das áreas hialinizadas se inicia alguns dias após a redução da pressão e as áreas são repopuladas com células normais. A penetração de novos capilares é um fator importante neste processo de reparação (RYGH, 1972a; FALTIN et al., 2001). A reabsorção radicular, embora não seja uma reação tecidual esperada, muitas vezes ocorre nos locais de compressão do ligamento periodontal onde são formadas áreas hialinizadas.

A reabsorção óssea parece iniciar-se nos espaços medulares adjacentes à área de pressão, fenômeno conhecido como reabsorção minante, fato que poderá influenciar na remoção do tecido hialinizado e ligamento periodontal. No osso alveolar adjacente ocorre o desaparecimento dos osteócitos, os quais deixam suas lacunas vazias caracterizando aspectos degenerativos (PICTON, 1969). Entretanto, alguns estudos revelaram que nas áreas de pressão os osteócitos do osso alveolar adjacente á zona hialinizada não apresentam alterações indicativas de degeneração ou morte tecidual (RYGH, 1973).

Com relação às alterações teciduais decorrentes da movimentação ortodôntica na zona de tensão, ocorre aumento acentuado nos espaços entre as estruturas do ligamento periodontal. As células do ligamento periodontal apresentam formato fusiforme e se encontram com seu longo eixo na direção da tração. Os osteoblastos migram e permanecem distribuídos a curta distância da superfície do osso alveolar, o que caracteriza a primeira resposta dessas células frente ao estimulo ortodôntico de tração (HIRASHITA, 1976). Os principais feixes de fibras também se orientam no sentido de tração. Ocorre aumento das fibras. Alterações vasculares são relevantes exceto por uma pequena dilatação dos vasos sangüíneos (RYGH, 1972a). No cemento 
depositado sobre a superfície radicular, muitas linhas incrementais irregulares são encontradas (RYGH, 1976). A deposição do novo osso ocorre ao longo da superfície do alvéolo progressiva com o aumento de tempo da movimentação (RYGH, 1976).

\subsubsection{Reabsorção Radicular}

Apesar de que, idealmente, a movimentação ortodôntica deveria transcorrer através de reações no osso alveolar e no ligamento periodontal, a reabsorção radicular é um efeito indesejável que ocorre freqüentemente durante a movimentação ortodôntica (BREZNIAK e WASSERSTEIN, 2002), e acredita-se que ocorra adjacente as áreas de pressão do ligamento periodontal (FALTIN et al., 1998, 2001; CASA et al., 2001, 2006; JIMENEZ-PELLEGRIN e ARANA-CHAVEZ 2004, 2007).

A reabsorção radicular é multifatorial podendo estar associada a fatores do próprio paciente, tais como idade, sexo, condição sistêmica, tipo de má oclusão, genética, bem como a fatores associados ao tratamento ortodôntico como a duração do tratamento, tipo de força aplicada, magnitude da força e tipo de movimentação dentária (BREZNIAK e WASSERSTEIN, 2002; PIZZO et al., 2007).

A reabsorção radicular causada por movimentação ortodôntica está relacionada à sobrecompressão causada no ligamento periodontal (MAVRAGANI et al., 2004), sendo um efeito colateral da atividade celular associada à remoção do tecido hialinizado (RYGH, 1977). RYGH e BRUDVIK (1993 a) relatam que o processo de reabsorção tem início na periferia do tecido hialinizado, sendo observado posteriormente na porção central da zona hialinizada; entretanto uma vez estabelecido ocorre simultaneamente em ambos locais. As primeiras células envolvidas no processo de remoção do tecido hialinizado são células multinucleadas, porém TRAP-negativas (BRUDVIK e RYGH, 1993 a). Outros tipos celulares, tais como "macrophagelike", "fibroblast-like", também são encontrados nessa fase inicial (BRUDVIK e 
RYGH, 1993 b). Com a penetração de macrófagos ocorre a degradação do cementóide, expondo parte do cemento mineralizado. Células gigantes multinucleadas sem borda em escova são as próximas a aparecerem e remover parte do tecido hialinizado, bem como parte do cemento (BRUDVIK e RYGH, 1994a). A reabsorção radicular abaixo da hialinização ocorre em uma fase tardia, quando já aparecem clastos que reabsorvem o cemento e a dentina (BRUDVIK e RYGH, 1994b). A reabsorção radicular continua até que toda a área hialinizada seja removida.

As áreas de reabsorção radicular são encontradas adjacentes à zona de hialinização e em locais onde houve a eliminação do tecido hialinizado (BRUDVIK e RYGH, 1994a).

Estudos demonstram que os tecidos não mineralizados atuam como barreiras contra o processo de reabsorção sendo esse papel desempenhado no cemento pela camada de cementóide (REITAN, 1974; RYGH, 1977). A eliminação da zona hialinizada faz com que ocorra a remoção do cementóide deixando a superfície radicular sem proteção (RYGH, 1977). Isto estaria de acordo com a idéia de que a camada de células sobre a superfície radicular forma uma barreira de proteção contra a reabsorção, preservando a integridade radicular.

Conforme mencionado anteriormente, o cemento tem a capacidade de neoformação, embora não seja comparável ao tecido ósseo. Isso permite que após sua reabsorção novas camadas de cemento possam ser formadas no local afetado. Quando uma força contínua é aplicada, é possível observar a reparação do cemento (FALTIN et al., 2001; CASA et al., 2006). Contudo, quando a reabsorção atinge a dentina, o cemento, na maioria das vezes, irá recobri-la com uma camada fina, não se recuperando a anatomia radicular inicial (ABELLEIRA et al., 1999). Devido a isso, são consideradas irreversíveis as reabsorções radiculares que atingem a dentina.

As respostas biológicas dos tecidos periodontais frente à movimentação ortodôntica dependem de diversos fatores, especialmente mecânicos, e 
didaticamente estes fatores são divididos em: magnitude de força, sentido da força, tipo de força, período de aplicação da força e quantidade de movimento.

\subsubsection{Magnitude de Força}

A quantidade de força atuará em um sistema biológico e, portanto, deve existir uma preocupação em se respeitar as leis biológicas do periodonto. Contudo, a magnitude não pode ser muito baixa, pois, assim não desencadearia a resposta desejada, e também não pode ser muito alta o que poderia levar a efeitos indesejáveis. Dessa forma a maioria das pesquisas nesta área busca uma força ideal para a movimentação dentária.

O termo gramas $(\mathrm{g})$ foi e ainda é bastante utilizado para medir força ortodôntica, no entanto, esta é uma medida usada para medir massa (peso). Por isso, considera-se Newton $(\mathrm{N})$ como o termo correto para medir quantidade de força, sendo $1 \mathrm{~N}=100 \mathrm{~g}$.

De acordo com Schwarz (1932) a força ideal considerada para a movimentação ortodôntica é aquela equivalente a pressão capilar, isto é, 20 a $25 \mathrm{cN} / \mathrm{cm}^{2}$. A aplicação de uma força dessa magnitude manteria a integridade do periodonto sem provocar reabsorções radiculares. No modelo animal alguns estudos sugeriram forças ideais para movimentações dentárias. Para Oppenheim (1944) uma força ideal para movimentação ortodôntica em ratos é de $20-25 \mathrm{cN} / \mathrm{cm}^{2}$. Para a intrusão em ratos, a força ideal seria uma força aproximada da pressão sangüínea sistólica $\left(16 \mathrm{cN} / \mathrm{cm}^{2}\right.$ ) (STEIGMAN e MICHAELI, 1981). Para um movimento de corpo em ratos a força ideal é de 10 cN (KOHNO et.al, 2002) o que está de acordo com Ren et al., 2004 que diz que em relação ao movimento de mesialização em ratos a força ideal proposta é também de $10 \mathrm{cN}$.

Existem controvérsias em relação à magnitude da força e a quantidade de reabsorções radiculares. Alguns estudos em humanos (CASA et al., 2001; FALTIN et al., 1998) e em animais (GONZALES et al., 2008) relacionaram 
diretamente à quantidade de força à quantidade de reabsorção concluindo que quanto maior a força, maior a reabsorção. Faltin et al. (1998), observaram em um estudo intra-individual em humanos que dobrando a magnitude de força (de $50 \mathrm{cN}$ para $100 \mathrm{cN}$ ) em intrusão de pré molares ocorria um aumento na quantidade de reabsorção. Gonzales et al. (2008) ao analisarem a movimentação (mesialização) em molares de ratos utilizando quatro magnitudes de força $(10,25,50$ e 100g) concluíram que a quantidade de reabsorção radicular depende da magnitude da força.

Entretanto, outras pesquisas não evidenciaram aumento significante de reabsorção radicular quando aplicadas duas magnitudes de forças (OWMANMOLL et al., 1996 a;b). Owman-moll et al. (1996a) afirmam em um estudo intraindividual em adolescentes que não evidenciaram aumento significante de reabsorção radicular (extensão e profundidade de contorno radicular reabsorvido) quando aplicadas forças de $50 \mathrm{cN}$ e $200 \mathrm{cN}$.

\subsubsection{Tipo de Força}

O tipo de força é um fator importante que influencia na movimentação ortodôntica. $\mathrm{O}$ tipo de força pode ser classificado em intermitente ou contínua. A força intermitente é aquela proporcionada por aparelhos removíveis, aparelhos fixos com a utilização de elásticos intermaxilares, ou aparelhos extrabucais, onde o nível de força declina até zero. A força contínua é proporcionada por aparelhos fixos com fios de níquel-titânio; e mantêm-se durante todo o período de aplicação. A força é transmitida ao dente (para que ocorra a movimentação ortodôntica) através do fio. Assim, um componente essencial dos aparelhos ortodônticos é o fio. O fio ideal deve liberar forças suaves e contínuas para que seja reduzida a hialinização e reabsorções minantes (KUSY, 1997). 
Uma das ligas mais utilizadas é a de aço inoxidável, que é composta por $18 \%$ de cromo, $8 \%$ de níquel, $71 \%$ de ferro e pequena quantidade de carbono $(0,5 \%)$. O cromo é responsável pelo aumento da resistência à corrosão e manchamento da liga ao meio bucal, o que the confere biocompatibilidade. Os fios de aço inoxidável são muito rígidos, ou seja, possuem alto módulo de elasticidade. Possuem baixo módulo de resiliência, isto é, os fios absorvem pouca energia, o que implica na produção de forças pesadas que se dissipam rapidamente necessitando de ativações constantes.

Por muito tempo os fios de aço inoxidável predominaram na ortodontia, mas com o passar do tempo surgiram novas ligas, como a de cromo-cobalto e de níquel-titânio.

Os fios de níquel titânio (NiTi) possuem efeito de memória, são capazes de retornar a sua forma e estrutura original após ser deformado (KUSY, 1997). Possuem baixo módulo de elasticidade, que lhe confere alta flexibilidade e alto módulo de resiliência (NAKANO et al., 1999) e com isso produzem forças mais suaves e constantes do que o aço inoxidável (GURGEL et al., 2001a).

Os fios de NiTi podem ser divididos em 2 grupos: os fios de $\mathrm{NiTi}$ convencionais e os fios superelásticos, os quais, por sua vez dividem-se em: pseudo-elástico e termoativado, cada um com propriedades únicas (KUSY, 1997).

Fios superelásticos são capazes de liberar forças verdadeiramente contínuas até um certo ponto de deformação do fio. Quando o fio atinge um ponto de deformação maior que o seu limite de elasticidade, a força começa a diminuir deixando de ser continua; porém, quando essa deformação diminui a força volta a ser continua (MIURA et al., 1986). A histerese é uma propriedade única dos fios superelásticos na qual a força de ativação (quantidade que se comprime o fio para colocar no slot do braquete) é maior que a força de deativação (real força exercida pelo fio) (GIL e PLANELL,1999).

Os fios superelásticos termoativados apresentam-se na fase ativa sob a forma martínsitica (KUSY, 1997) que é a forma menos rígida da liga de NiTi, e sua estrutura cristalina se apresenta em forma hexagonal compacta, diferente 
dos fios de aço que se apresentam na forma austenítica e sua estrutura espacial é de forma cúbica (GURGEL et al, 2001b). A memória de forma, nos fios superelásticos termoativados é decorrente das transformações cristalográficas induzidas por alterações na temperatura. Durante o processo de fabricação a liga é aquecida e moldada com a estrutura na forma martensítica. Quando resfriada a temperatura ambiente, o arco de NiTi modifica-se e fica sobre a forma austenítica. Ao ser posicionado na boca, com a temperatura em torno de $36^{\circ} \mathrm{C}$ (temperatura corpórea) a grade cristalina é induzida a retornar para a conformação martensítica e com isso retorna a forma ideal (KAPILA e SACHDEVA,1989).

No entanto, com a evolução da ortodontia o desenvolvimento de fios de níquel-titânio superelásticos permitiu a possibilidade da aplicação de uma força contínua sobre os elementos dentais. Poucos estudos analisaram as respostas teciduais dos tecidos periodontais de sustentação frente a tais estímulos. Owmam-moll et al.(1995) realizaram um trabalho, em humanos, comparando forças contínua e intermitente, onde ficou evidenciado que não há diferença significante na quantidade ou severidade de reabsorção radicular entre os dois tipos de força. Estudos em humanos que utilizaram forças ortodônticas contínuas, avaliando a ultra-estrutura do cemento e ligamento periodontal sob estímulos ortodônticos de intrusão (FALTIN et al., 1998, 2001) e torque (CASA et al., 2001) sugeriram que não é necessário o declínio da força para que ocorra a reorganização e reparação dos tecidos periodontais. Além disso, foram encontrados cementoblastos na periferia das áreas hialinizadas bem como nas lacunas que foram reabsorvidas. Casa et al. (2006) demonstraram a presença de células clásticas em contato com as lacunas de reabsorção no lado de pressão, e que o número de clastos e a extensão da reabsorção aumenta com longos períodos de aplicação de força.

Entretanto, nestes estudos não foi possível avaliar a resposta do osso alveolar frente a esse tipo de carga. Bonafe-Oliveira et al. (2003) padronizaram um modelo animal no qual é possível avaliar as respostas de todo o periodonto de sustentação frente a esse tipo de força e demonstraram que a reabsorção 
coexiste com a formação óssea no lado de pressão, sugerindo não ser necessário o declínio da força para que ocorra a movimentação dentária ortodôntica. Além disso, observaram a dinâmica das respostas teciduais que acontecem nas áreas de pressão e de tração. Nas áreas de pressão foram encontradas numerosas concavidades contendo osteoclastos e osteoblastos sobre as lacunas previamente reabsorvidas. Áreas de hialinização restringiamse ao ligamento periodontal. Hemácias apresentaram-se envolvidas por células gigantes, provavelmente macrófagos, vindos da corrente sanguínea para remover os restos da hialinização do ligamento periodontal e proporcionar o início de sua reestruturação. Em nenhum momento a hialinização causou danos irreversíveis ao periodonto de sustentação, ao contrário, talvez essa reação tecidual esteja envolvida no processo de estimulação da movimentação ortodôntica, ou seja, sua presença pode gerar agentes quimiotáticos que atraem células de reabsorção óssea, os osteoclastos. Nesse estudo, foi encontrado um tipo de movimento chamando inclinação controlada, onde as respostas do periodonto de sustentação se alteravam, ou seja, os eventos observados com 3 dias se repetiam aos 7 dias, da mesma forma que os eventos ocorridos aos 5 dias se repetiam aos 10 dias (BONAFE-OLIVEIRA, 2006). Como as alterações foram mais severas no último período, é possível que as reações possam mudar se examinadas em tempos posteriores aos 10 dias. 
3 PROPOSIÇÃO 
O presente trabalho tem como objetivo o estudo das reações teciduais que ocorrem no cemento, ligamento periodontal e osso alveolar, em molares de ratos que foram submetidos a força contínua "fisiológica" de vestibularização analisando os seguintes aspectos:

- Avaliação da presença de reabsorção óssea e radicular, bem como da presença de células clásticas;

- Análise ultra-estrutural das respostas do peridonto de sustentação;

- Imunolocalização ultra-estrutural da presença e distribuição de OPN durante a remodelação óssea estimulada pela força ortodôntica contínua. 
4 MATERIAIS E MÉTODOS 


\subsection{Biomecânica}

A biomecânica utilizada para promover movimento de vestibularização dos primeiros molares superiores (direito e esquerdo) gerando uma força contínua de $15 \mathrm{cN}$, foi instalada sob anestesia geral. Para tanto, os animais foram anestesiados com Ketalar/Rompun, numa dose de $4 \mathrm{ml} / \mathrm{kg}$ via intramuscular. A ancoragem do aparelho foi instalada nos incisivos, enquanto a parte ativa foi fixada com resina composta (Transbond XT - 3M) na face palatina dos primeiros molares superiores. O modelo biomecânico utilizou uma ancoragem anterior, estabilizando o aparelho com o intuito de evitar possíveis contatos diretos provenientes da mastigação, os quais poderiam influenciar na força aplicada. Para obtenção da ancoragem anterior junto aos incisivos superiores anterior, foi utilizado fio de aço $0,5 \mathrm{~mm}$ (Federhart, Dentaurum), o qual foi submetido à solda-prata (45\%), unindo-o a um tubo de .018"x .025", através do qual, será inserida a porção ativa do aparelho, composta de fio ortodôntico .016" $(0,40 \mathrm{~mm})$, de NiTi- SE, (Forestadent, Bernhard Förster Gmbh, Pforzheim/Germany), consistindo em fios superelásticos. Para uma melhor fixação da parte ativa nos dentes que foram submetidos aos estímulos ortodônticos foram utilizados braquetes de aço $(0,8 \times 0,8 \mathrm{~mm})$ com slot compatível ao diâmetro do fio. Estes foram fixados com resina composta (Transbond XT - 3M) na face palatina dos $1^{\circ}$ molares superiores. Em seguida, o fio ortodôntico foi fixado no slot do braquete com a mesma resina composta (Figura 1). 


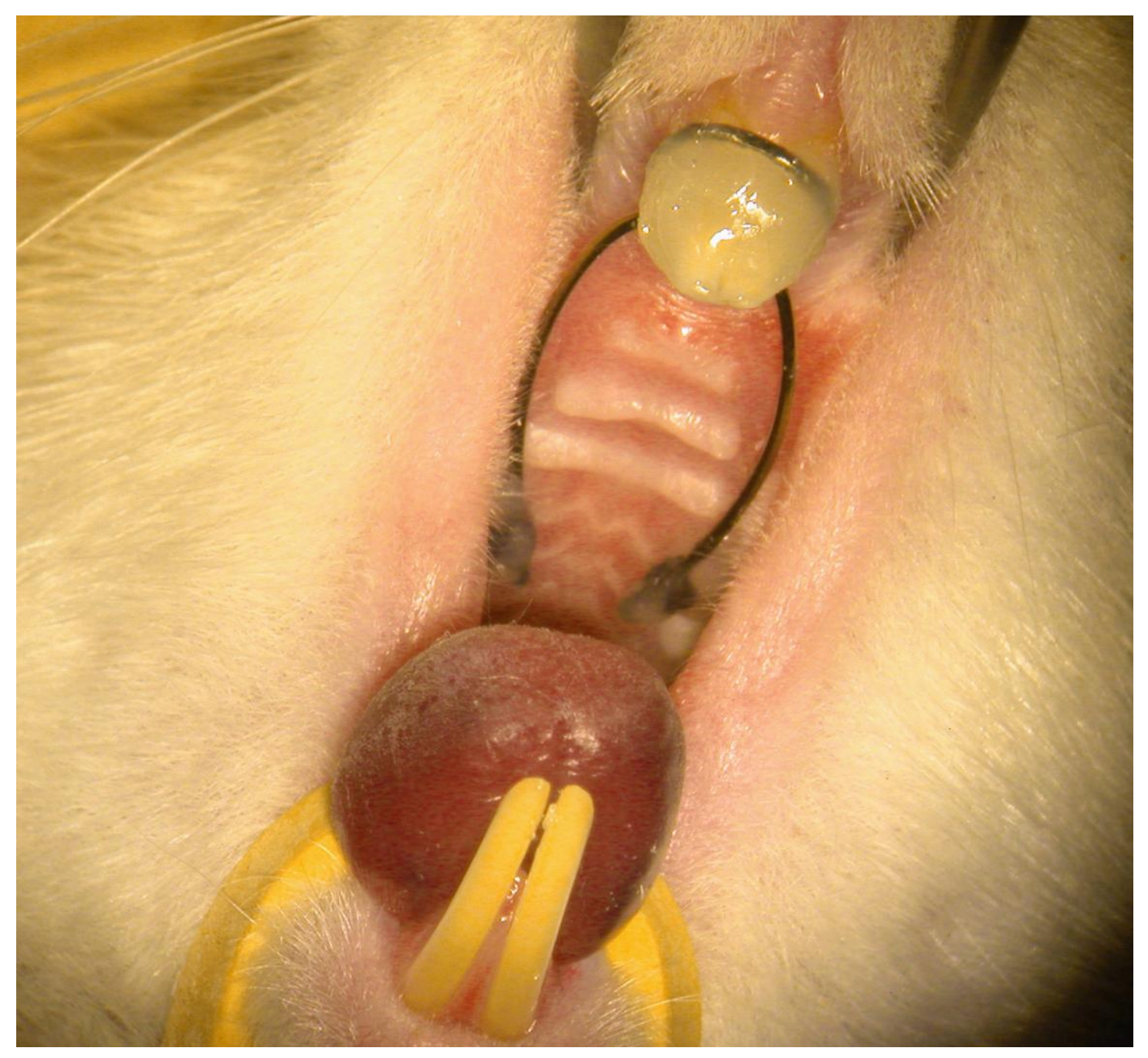

Figura 1- Biomecânica instalada no rato para vestibularização dos primeiros molares superiores. 
Para o desenho e construção dos braquetes, as maxilas de dois ratos foram moldadas com alginato obtendo-se os modelos de gesso.

Os fios utilizados no presente estudo foram calibrados individualmente na Universidade de Ulm, Alemanha, seguindo os padrões já utilizados nos estudos realizados anteriormente no laboratório (FALTIN et al., 2001; CASA et al., 2001,2006; BONAFE-OLIVEIRA et al., 2003). O experimento realizado para calibração dos fios consistiu no seguinte procedimento: os fios foram inseridos em um recipiente cuja temperatura interna aproximava-se da temperatura corporal do rato, a qual é semelhante a do corpo humano, ou seja, por volta dos $36^{\circ} \mathrm{C}$. Posteriormente, dois sensores localizados nas extremidades do arco, fizeram a constrição do mesmo até a posição da distância transversa intermolares de ratos (obtida através da mensuração de diversos modelos de gesso de animais com mesma idade e peso), o que consistiu em uma constrição de $9 \mathrm{~mm}$. A força liberada pelo arco foi mensurada a cada milímetro de constrição do mesmo e o gráfico resultante consistiu de duas curvas : a de ativação do fio ( obtida durante a constrição ) e a de deativação ( obtida apos a liberação do fio, até o retorno à sua posição inicial). A força liberada pelo fio durante a curva de ativação é maior do que a força liberada durante a curva de deativação, graças ao fenômeno denominado histerese, característico dos fios de NiTi superelasticos. Os cinco gráficos obtidos, correspondem ao número de vezes que 0 experimento foi realizado,com 0 intuito de comprovar a especificidade do mesmo. Segundo o experimento, a força aplicada nos molares de ratos para vestibulariza-los foi em torno de $15 \mathrm{cN}$ ( Figura 2).

Esses fios apresentam uma memória estrutural intrínseca que lhes confere propriedades físicas especificas com as quais se pode obter uma mesma magnitude de força por um grande intervalo de deformação, permitindo, devido a essas características a aplicação de forças verdadeiramente contínuas na movimentação ortodôntica (WICHELHAUS e SANDER, 1994). 


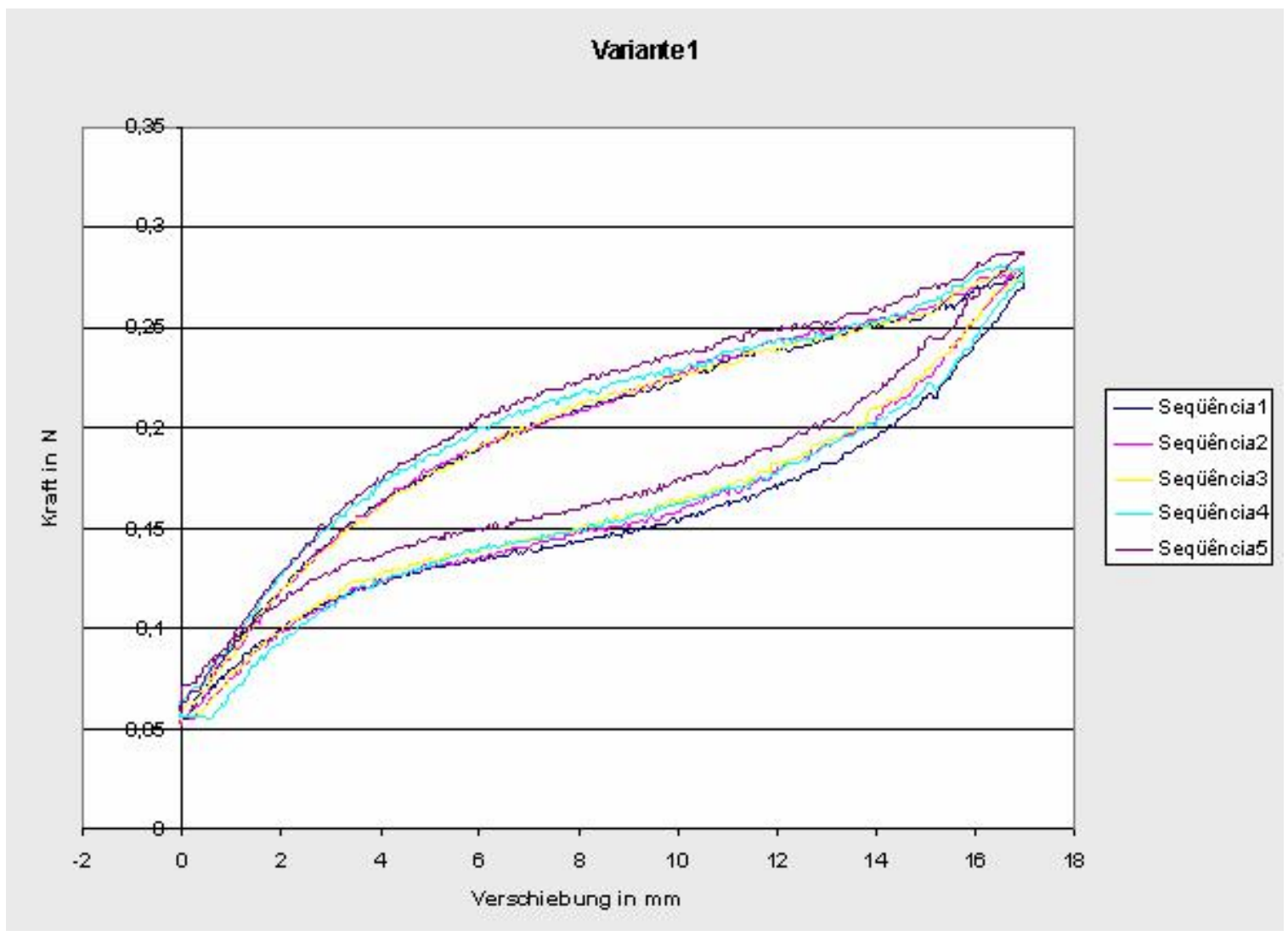

Figura 2- Gráfico de curva/deflexão. 


\subsection{Tempos de aplicação de força contínua e obtenção dos espécimes}

Trinta ratos, machos, Wistar, com dois meses e meio de idade (peso aproximado entre $210-220 \mathrm{~g}$ ) foram utilizados no presente estudo. Em seis animais, todos os componentes da biomecânica desenvolvida para esse estudo foram instalados, exceto o fio de NiTi. Sendo assim, os molares desses animais não foram vestibularizados, constituindo o grupo controle. Esses animais foram divididos igualmente em 3 grupos e constituíram o controle das reações de TRAP, imunocitoquimica e morfologia. Os vinte e quatro animais restante foram divididos igualmente em 3 grupos e os primeiros molares superiores foram submetidos à força continua de $15 \mathrm{cN}$ por 12, 15 e 18 dias. Em cada um desses grupos, constituídos por 8 animais, os espécimes obtidos de três animais foram processados para analise morfológica ultra- estrutural; os espécimes de dois animais foram processados para análise histoquímica (TRAP) para a identificação de células clásticas enquanto que os espécimes dos três animais restantes foram processados para imunocitoquímica para a identificação de osteopontina.

A instalação desta biomecânica fixa com fios superelásticos foi testada e padronizada, tendo sido comprovada que permanece os 18 dias necessários para o experimento.

\subsection{Microscopia Eletrônica de Transmissão: Morfologia}

Os animais foram anestesiados com Ketalar/Rompum, como descrito acima, e decapitados. As maxilas foram dissecadas e rapidamente imersas em solução de formaldeído a 2,5\% (preparado do paraformaldeído) + $2 \%$ glutaraldeído tamponado com cacodilato de sódio 0,1M, ph 7,2 (ARANACHAVEZ et al., 1995). Todos os tecidos moles foram removidos cuidadosamente. Os espécimes foram imersos em um beaker contendo $40 \mathrm{ml}$ de fixador em temperatura ambiente, os quais foram subseqüentemente colocados em um recipiente de vidro cheio de gelo e colocados em um forno 
microondas de laboratório Pelco 3440 (Ted Pella, Redding, CA, USA). A sonda termométrica do forno ficou submersa dentro do fixador e os espécimes foram imediatamente expostos à radiação de microondas por três períodos de 5 minutos com uma temperatura máxima de $37 \stackrel{\circ}{\circ}$ (MASSA e ARANA-CHAVEZ, 2000; ARANA-CHAVEZ e NANCI, 2001).

Depois da irradiação do microondas, os espécimes foram transferidos para um fixador novo e deixados durante toda a noite à $4{ }^{\circ} \mathrm{C}$. Eles então foram lavados em tampão cacodilato de sódio, $0,1 \mathrm{M}, \mathrm{pH} 7,2$ por uma hora. $\mathrm{A}$ descalcificação das maxilas foi em uma solução aquosa de EDTA a 4,13\% (Warshawsky e Moore, 1967) por um mês. Após a descalcificação, as regiões contendo os primeiros molares movimentados foram cortadas com uma navalha. Os espécimes foram lavados extensivamente em uma solução tampão de cacodilato de sódio a $0,1 \mathrm{M}, \mathrm{pH}$ 7.2. Os espécimes foram pósfixados em tetróxido de ósmio a $1 \%$ por duas horas, à temperatura ambiente. Todas as amostras foram desidratadas em concentrações crescentes de álcool e infiltradas em resina Spurr.

Cortes semifinos no sentido vestíbulo palatino, de $1 \mathrm{~mm}$ de espessura e corados com azul de toluidina foram examinados em microscópio de luz. Regiões contendo as raízes dos primeiros molares movimentados foram selecionadas para posteriores cortes ultrafinos de $80 \mathrm{~nm}$ de espessura, os quais foram obtidos com uma faca de diamante em um ultramicrótomo Reichert Ultracut E. Os cortes ultrafinos foram coletados em telas de cobre de 200 "meshes" e foram contrastadas com acetato de uranila e citrato de chumbo e examinados em um microscópio eletrônico JEOL 1010, operado a 80 kv.

\subsection{Microscopia de Luz: Método Histoquímico do TRAP}

Os espécimes obtidos para a realização de histoquímica TRAP foram fixados e descalcificados como descrito para microscopia eletrônica de transmissão. Posteriormente, foram cuidadosamente lavados e desidratados em concentrações crescentes de etanol. Logo após o material foi infiltrado e 
incluído em resina histológica JB-4 (Polysciences), utilizando a solução A com o catalisador $\mathrm{C}$ em 4 trocas de 30 min no girador, posteriormente as amostras foram incluídas em solução completa em cápsulas de gelatina. Cortes de aproximadamente $3 \mu \mathrm{m}$ foram realizados em micrótomo (Microm HM 360) com a utilização de facas de vidro, sendo estes colocados em lâminas resfriadas e deixados para em estufa a $37^{\circ} \mathrm{C}$ por 3 dias.

Para o procedimento histoquímico propriamente dito com o método do TRAP (fosfatase ácida resistente ao tartarato) foi inicialmente preparada solução completa de Burstone dissolvendo $4 \mathrm{mg}$ de naphthol AS-BI phosphate substrate (Sigma; St. Louis, MO) em 0,25 ml de N,N dimetil formida, seguido da adição de $25 \mathrm{ml}$ de tampão acetato 0,2M (pH 5,0), $35 \mathrm{mg}$ de Fast Red Violet LB ou Fast Garner GBC (Sigma), e $60 \mu \mathrm{l}$ de MgCl a 10\%. Logo após, a solução foi filtrada, o substrato desprezado e colocados $25 \mathrm{ml}$ na jarra Coplin, após o aquecimento da solução a $37^{0} \mathrm{C}$, foi acrescida de tartarato de sódio (Sigma), ou L (+) ácido tartárico, sal disôdica (Sigma), ou $\mathrm{D}(-)$ ácido tartárico (Sigma), na concentração de $50 \mathrm{mM}$. As lâminas de vidro contendo o material foram incubados por $2 \mathrm{~h} 30$ min.(COLE e WALTERS, 1987). Depois da incubação as lâminas foram lavadas por 30 min. em água corrente, deixadas para secar a $25{ }^{0} \mathrm{C}$ e contracoradas com solução alcoólica de hematoxilina de Harris a 10\% por aproximadamente 7 min (BONAFE-OLIVEIRA et al., 2003). Finalmente as lamínulas foram montadas utilizando Euparol (Gallard-Schlesinger Chem Mfg.Corp.; Carle Place, NY). O material foi observado e fotografado em microscópio de luz Nikon, Optiphot-2.

\subsection{Imunocítoquimica pós-inclusão com ouro coloidal}

Os espécimes obtidos foram rapidamente fixados em solução de glutaraldeído a 0,1 \% + formaldeído a 4\% (preparado do paraformaldeído) tamponado com cacodilato de sódio $0.1 \mathrm{M}-\mathrm{pH} 7,2$. O procedimento de fixação em microondas foi o mesmo já descrito, bem como o processo de descalcificação em EDTA. Todas as amostras foram desidratadas em 
concentrações crescentes de álcool e infiltradas em resina LR White (London Resin Company Ltda, England).

Cortes semifinos de $1 \mu \mathrm{m}$ corados com azul de toluidina foram examinados em microscopia de luz e regiões contendo as raízes dos primeiros molares movimentados foram selecionadas para os posteriores cortes ultrafinos de 80 $\mathrm{nm}$ de espessura, os quais foram obtidos com uma faca de diamante no ultramicrótomo Reichert Ultracut E e coletados em telas de níquel de 200 "meshes" cobertas com película de parlodion.

Os cortes foram processados para imunomarcação usando um anticorpo de galinha anti osteopontina de rato (OPNy), diluído 1:100 por 11 horas, e depois incubados com anticorpo secundário IgG de coelho anti-galinha (Sigma) diluído em 1:2000 por uma hora. Os sítios de ligação foram revelados colocando-se a tela sobre uma gota do complexo proteína A-ouro por quarenta e cinco minutos. As telas foram lavadas com PBS entre cada incubação. Antes de cada incubação, os sítios inespecíficos foram bloqueados colocando-se as telas sobre uma gota de PBS-1\% ovalbumina por vinte minutos. Após a proteína A-ouro, as grades foram lavadas com PBS seguido de água destilada.

Todos os passos foram realizados à temperatura ambiente. Os cortes foram contrastados com acetato de uranila e citrato de chumbo e examinado no microscópio eletrônico JEOL 1010 operado a $80 \mathrm{kV}$. O controle da especificidade da marcação consistiu na incubação com anticorpo proteínas não relacionada com o anticorpo secundário seguido pela proteína $A$-ouro ou só com proteína-A (ARANA-CHAVEZ e NANCI, 2001). 
5 RESULTADOS 


\subsection{Grupo Controle}

No grupo controle o periodonto de sustentação apresentou características normais, ou seja, a superfície do cemento apresentou-se lisa e contínua; no osso alveolar, a presença de poucos osteoclastos ativos identificou uma baixa atividade de reabsorção óssea. O ligamento periodontal apresentou fibrilas colágenas intactas e fibroblastos sem qualquer tipo de alteração em toda sua extensão (Figura 3).

Os resultados dos grupos movimentados serão descritos a seguir para cada período experimental:

\subsection{Doze dias de aplicação de força}

\subsection{1 Áreas de Tração}

Após doze dias de movimentação, as áreas de tração estavam localizadas nos seguintes terços: terço apical da face vestibular da raiz vestibular, terço cervical da face palatina da raiz vestibular, terço apical da face vestibular da raiz palatina, terço cervical da face palatina da raiz palatina, como mostra o esquema 1:

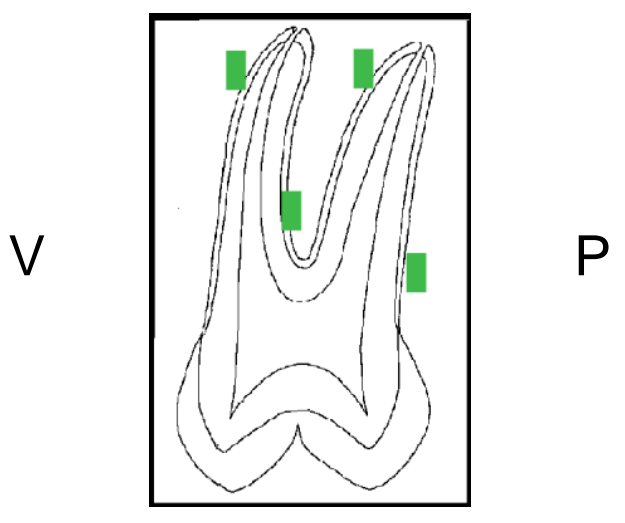

Esquema 1: áreas de tração, em verde. 

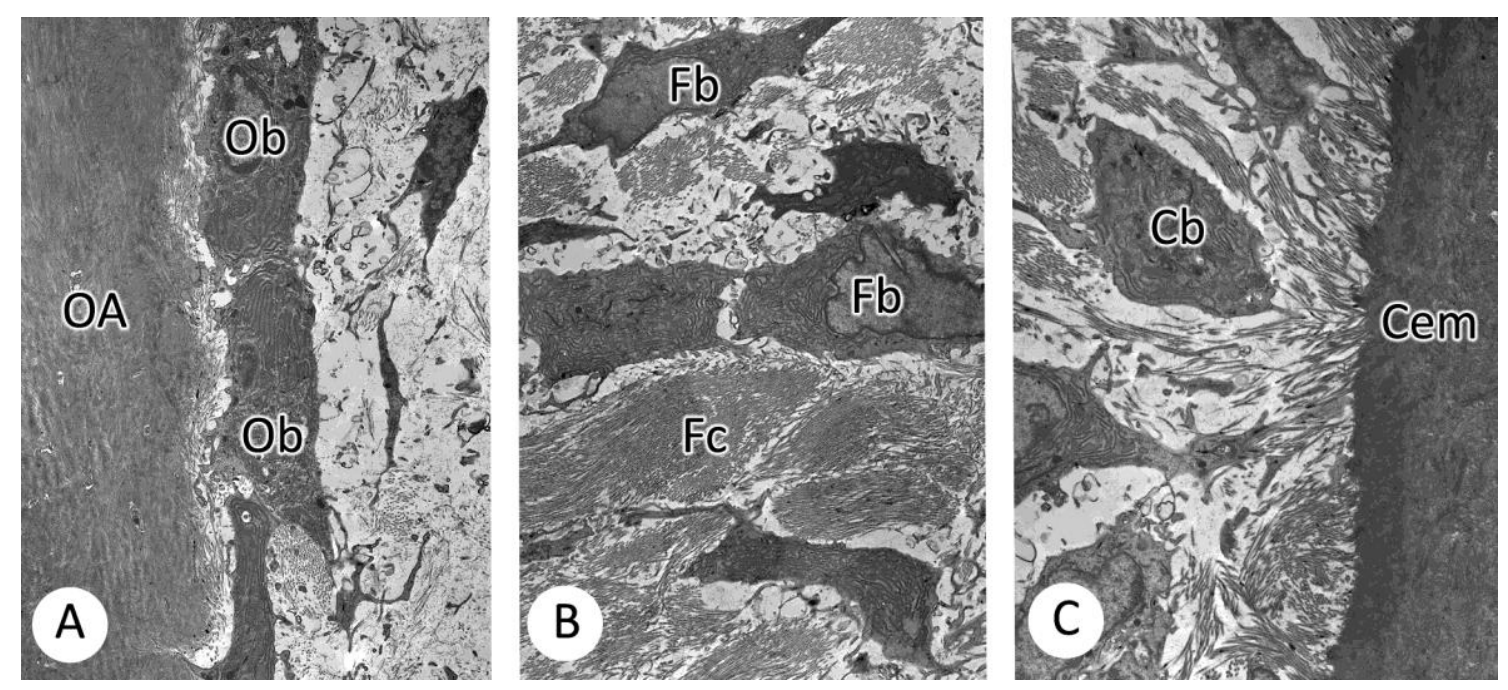
Nessas regiões houve predominância de neoformação óssea. Onde em microscopia de luz foram encontrados alguns osteoclastos ativos aderidos à matriz mineralizada, ultra-estruturalmente foi visto, entretanto, a presença de osteoblastos sobre as lacunas previamente reabsorvidas. Essas concavidades apresentavam uma linha mais corada na superfície e células mononucleares adjacentes (Figura 4). Tanto o cemento quanto o ligamento periodontal apresentaram-se intactos nesse período (Não mostrado).

Em microscopia eletrônica foi possível observar grande quantidade de osteoblastos ativos adjacentes uns aos outros, contendo em seu citoplasma muitas organelas de síntese de proteínas, retículo endoplasmático rugoso e complexo de Golgi bem desenvolvido. Tais células apresentavam-se sobre uma camada de matriz óssea não mineralizada recém sintetizada ou osteóide (Figura $5 \mathrm{~A}$ e B). A matriz óssea recém sintetizada nestas áreas apresentou fibrilas colágenas desorganizadas com amplos espaços interfibrilares (Figura 5C), características essas de um osso sintetizado rapidamente (osso imaturo ou primário).

O ligamento periodontal dessas regiões apresentou-se, na maioria das vezes, sem qualquer alteração, contendo fibroblastos e fibrilas colágenas intactas constituindo feixes (Figura 6A). O cemento apresentou características normais, sem qualquer sinal de reabsorção de sua superfície ou degeneração no interior da matriz, o qual apresentou cementócitos normais dentro de suas lacunas, fibras de Sharpey inseridas e cementoblastos próximos ao cemento (Figura 6B). Apesar da predominância de reações neoformação óssea, também foi possível observar nas áreas de tração a presença de alguns osteoclastos ativos sobre a superfície mineralizada (Não mostrado).

\subsection{2Áreas de Pressão}

Após doze dias de movimentação as áreas de pressão estavam localizadas em regiões opostas à das áreas de tração nos seguintes terços: terço cervical da face vestibular da raiz vestibular, terço apical da face palatina 


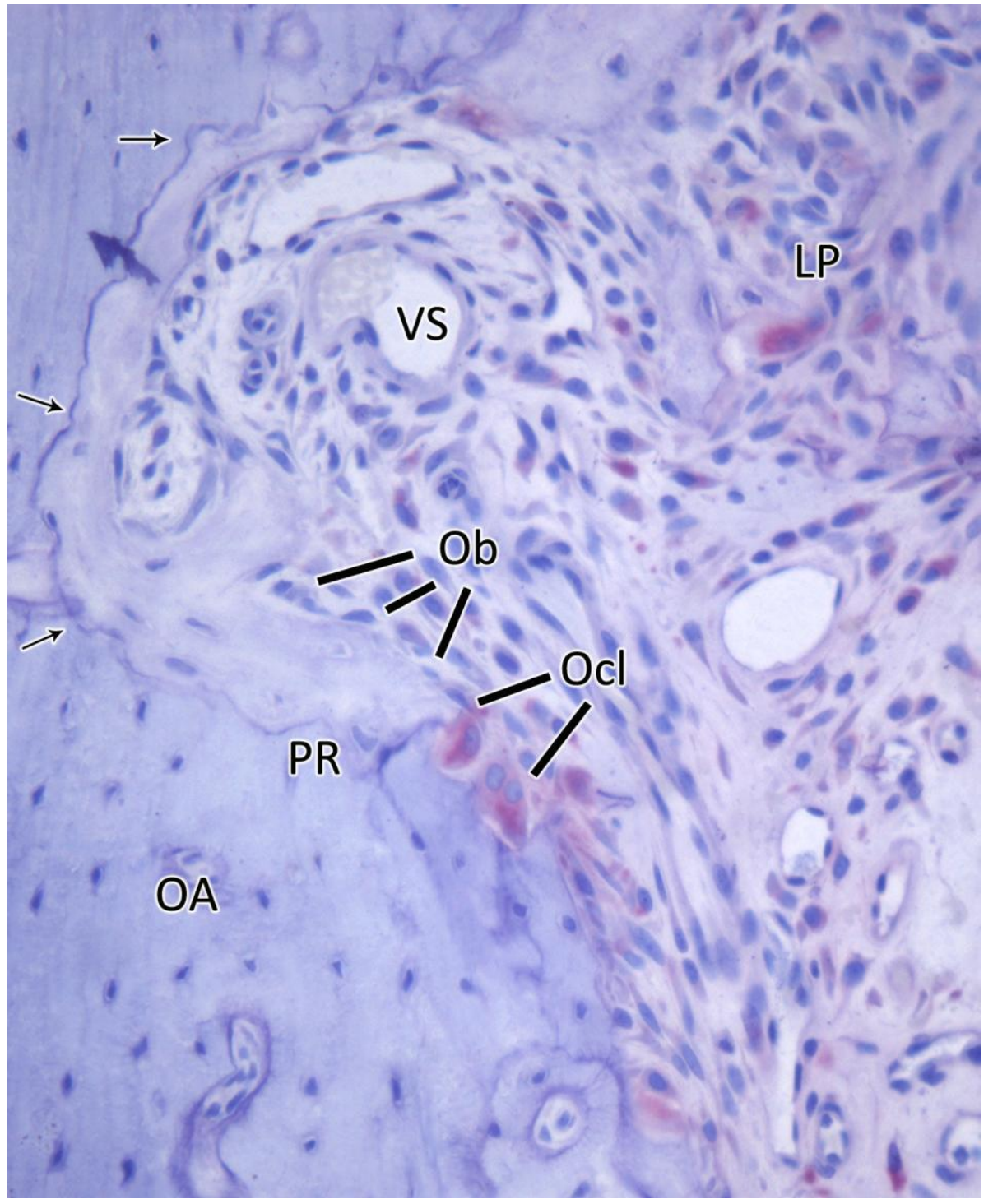



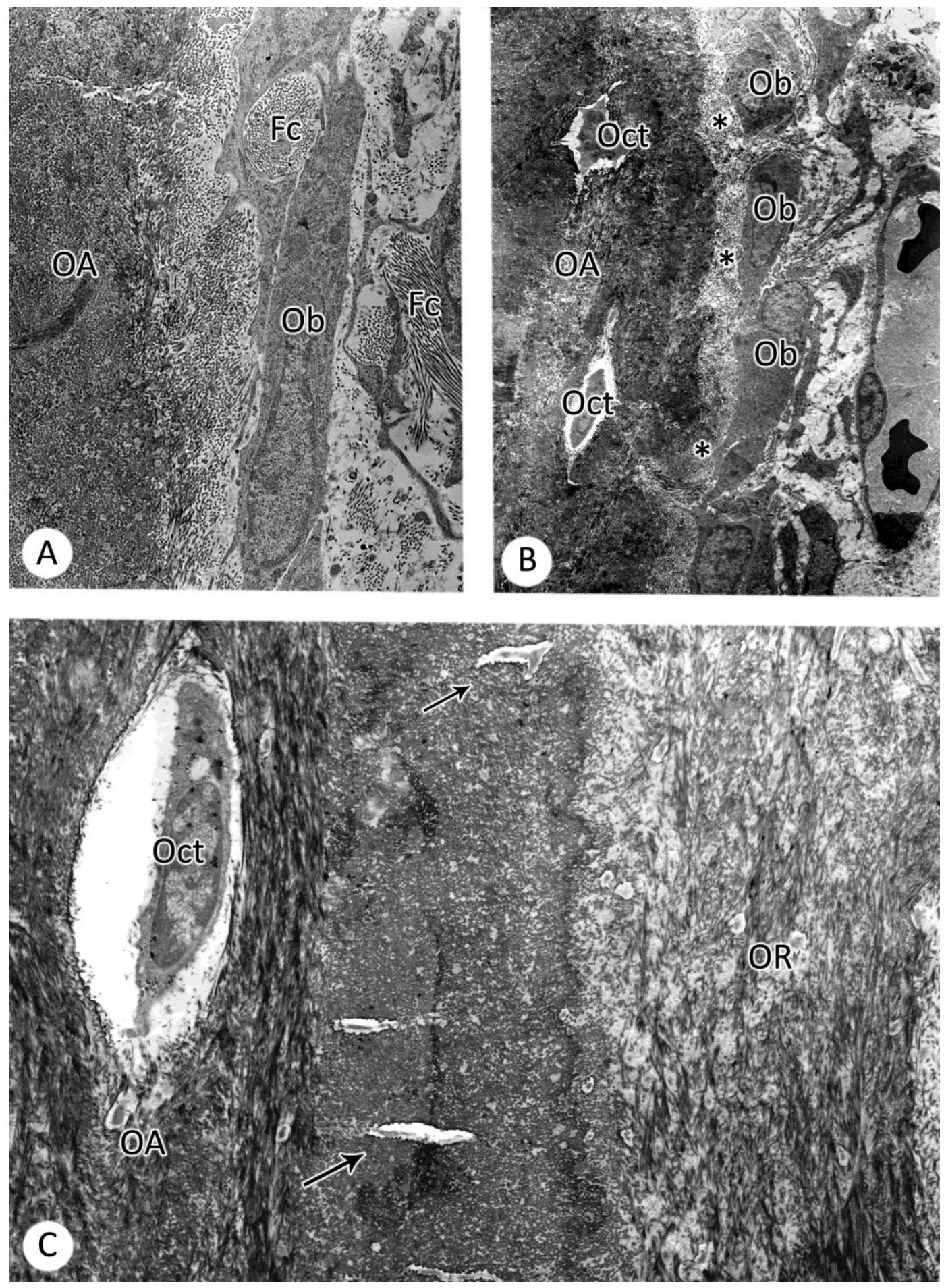

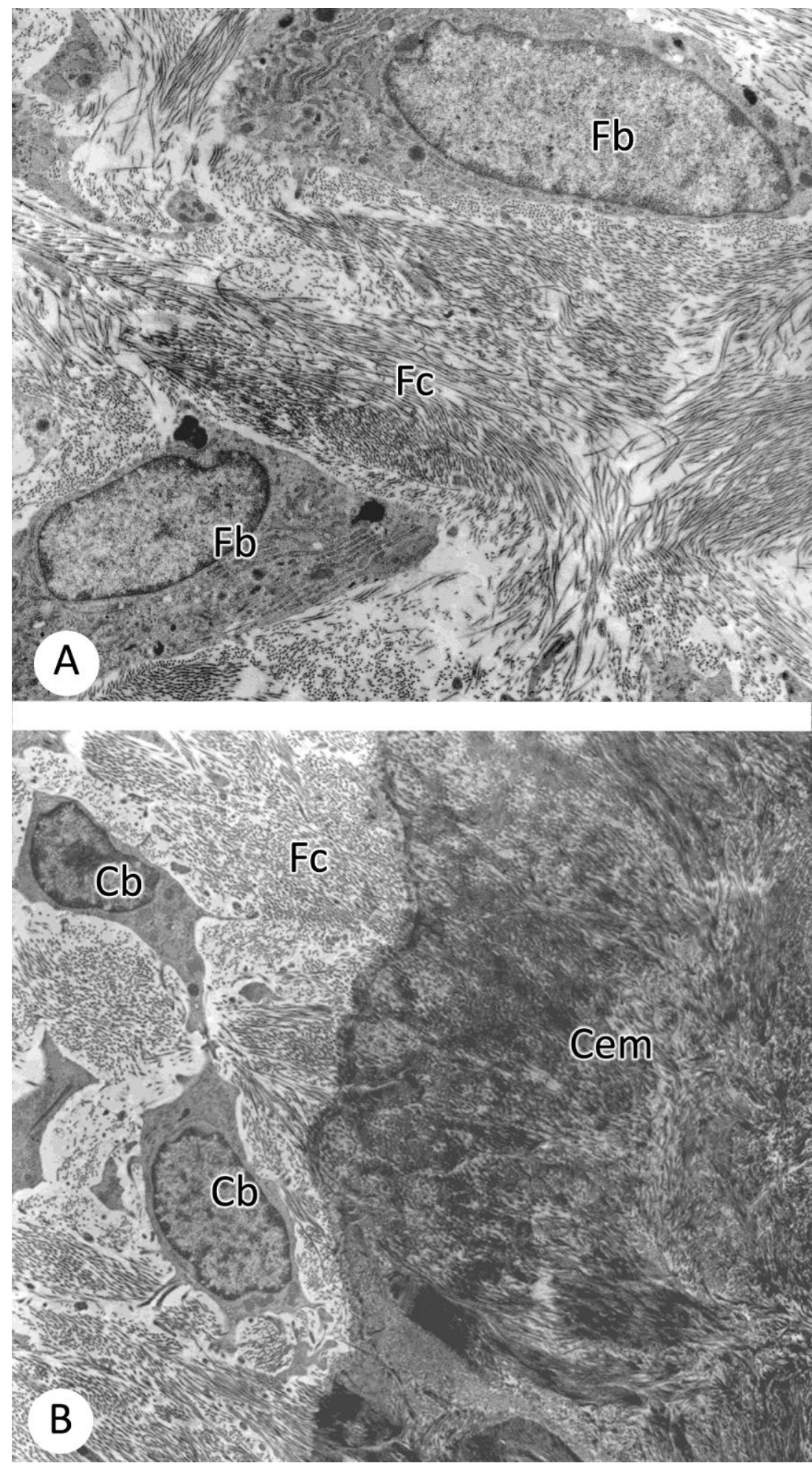
da raiz vestibular, terço cervical da face vestibular da raiz palatina, terço apical da face palatina da raiz palatina, como mostra o esquema 2 :

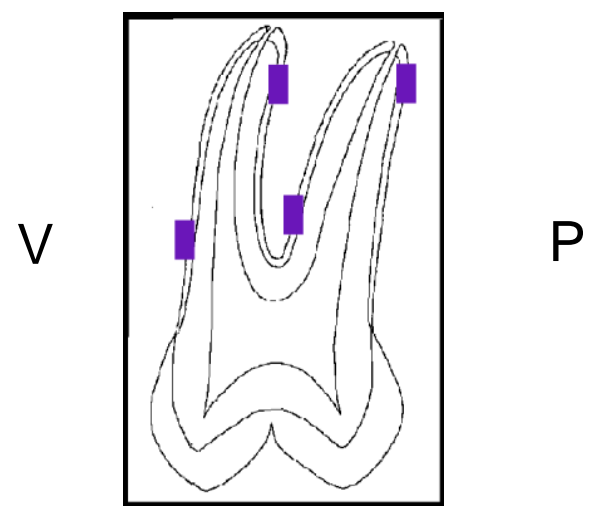

Esquema 2: áreas de pressão, em roxo.

Em microscopia de luz foi possível observar, nas áreas de pressão, osteoclastos ativos aderidos à matriz óssea; no entanto, células mononucleares também estavam presentes nessa região. Pequenas áreas hialinizadas com aspecto homogêneo eram observadas no ligamento periodontal, enquanto que o cemento apresentava-se intacto (Figura 7).

O osso alveolar dessas áreas apresentou características tanto de osso primário como de osso maduro, com predominância de osteoclastos ativos com borda em escova bem desenvolvida e zona clara evidente, reabsorvendo a matriz mineralizada. Em algumas regiões foi possível encontrar osteoclastos em contato com osteócitos no interior de sua lacuna (Figura 8A). Embora a reabsorção tenha ocorrido com maior predominância nessas áreas, foi possível encontrar áreas em que células mononucleadas estavam adjacentes aos osteoclastos ativos (Figura 8B). Além disso, regiões com neoformação óssea estavam presentes, sendo possível observar linhas cimentantes entre o osso antigo e o osso recém sintetizado, este com fibras desorganizadas e osteoblastos ativos adjacentes a essas áreas (Figura $8 \mathrm{C}$ ).

O ligamento periodontal dessas regiões apresentou-se hialinizado, com presença de restos celulares entre as fibras colágenas degeneradas e macrófagos (Figura 9 A e B). Áreas hialinizadas foram comuns nas áreas de 


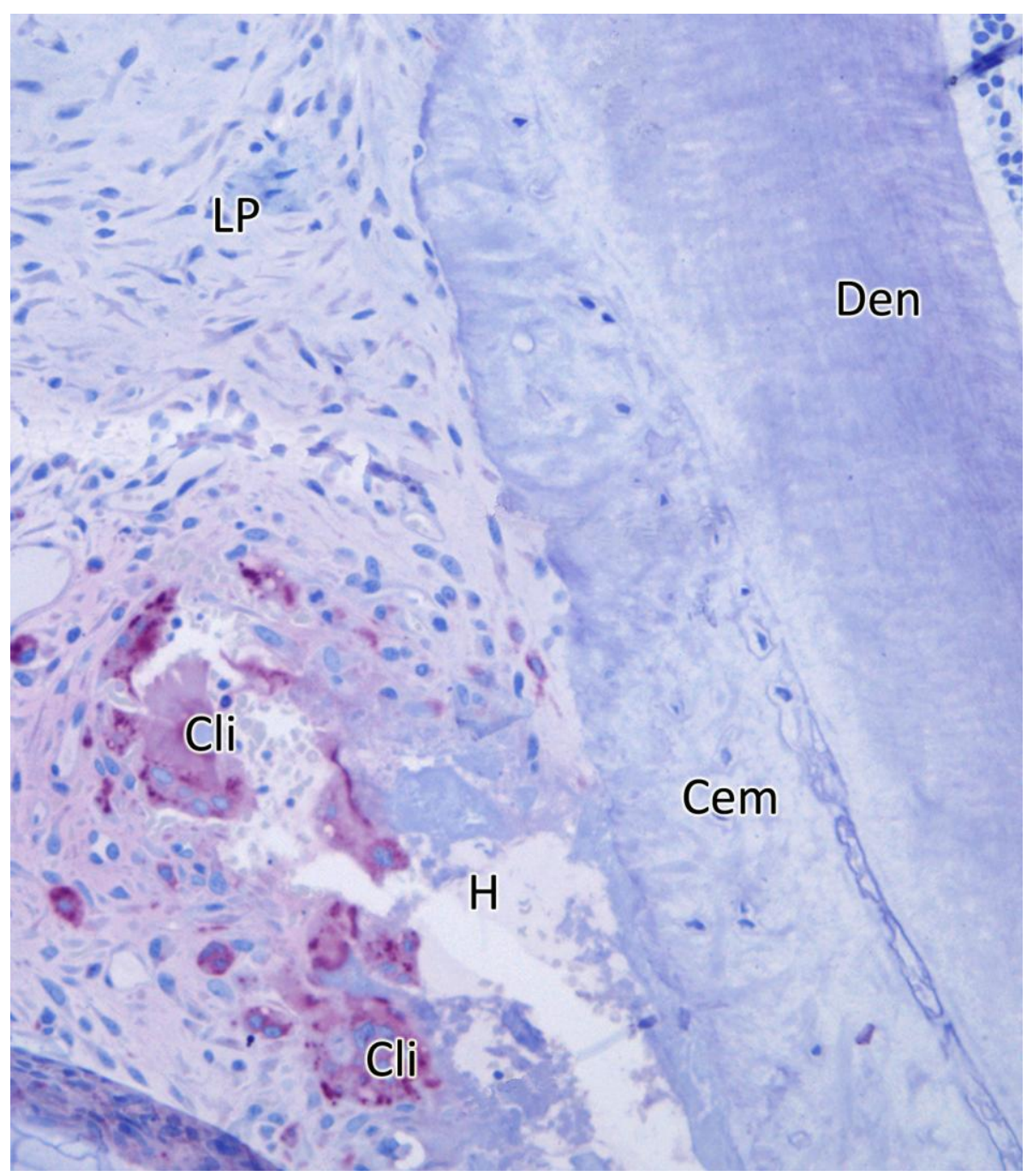



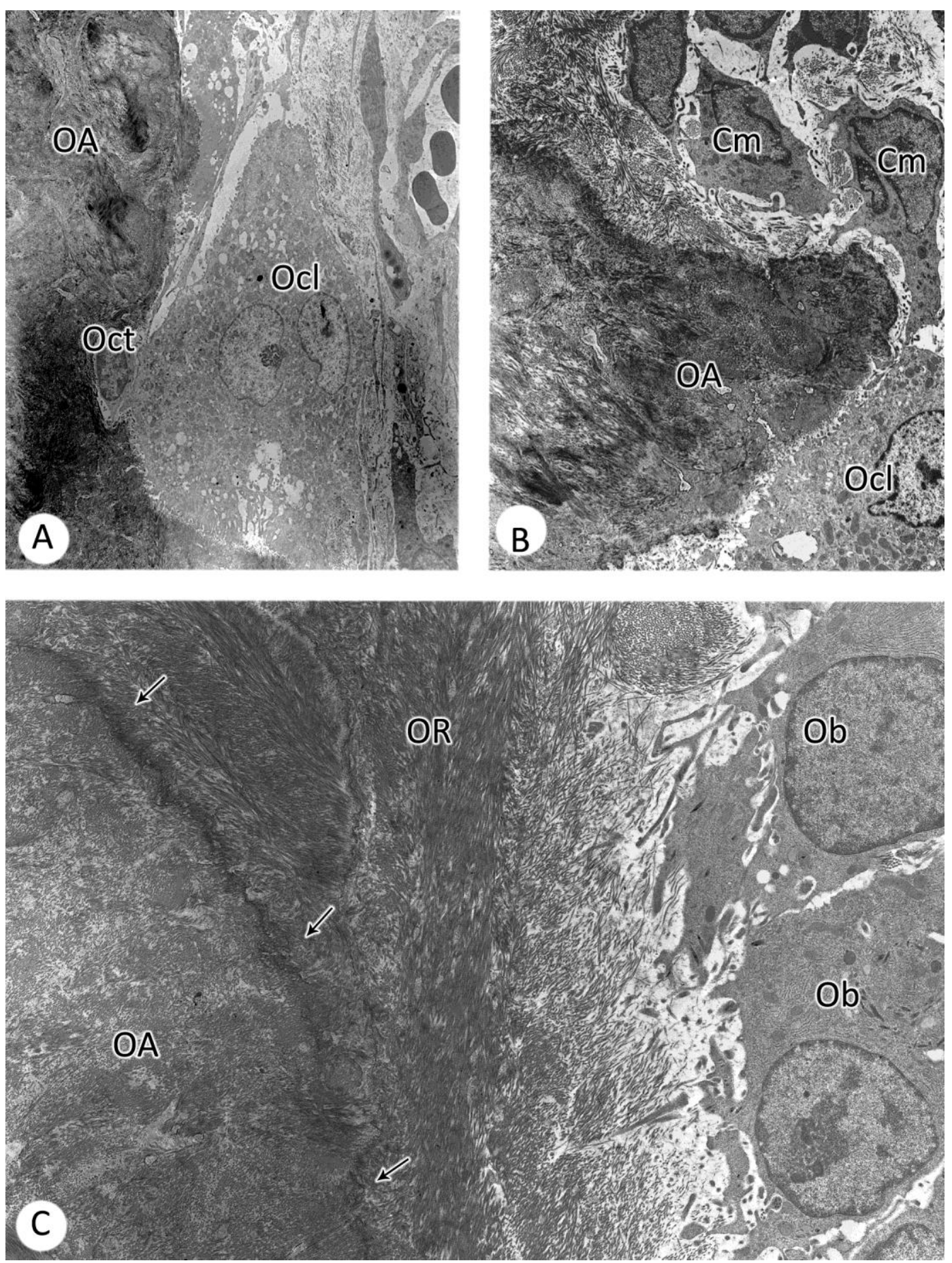

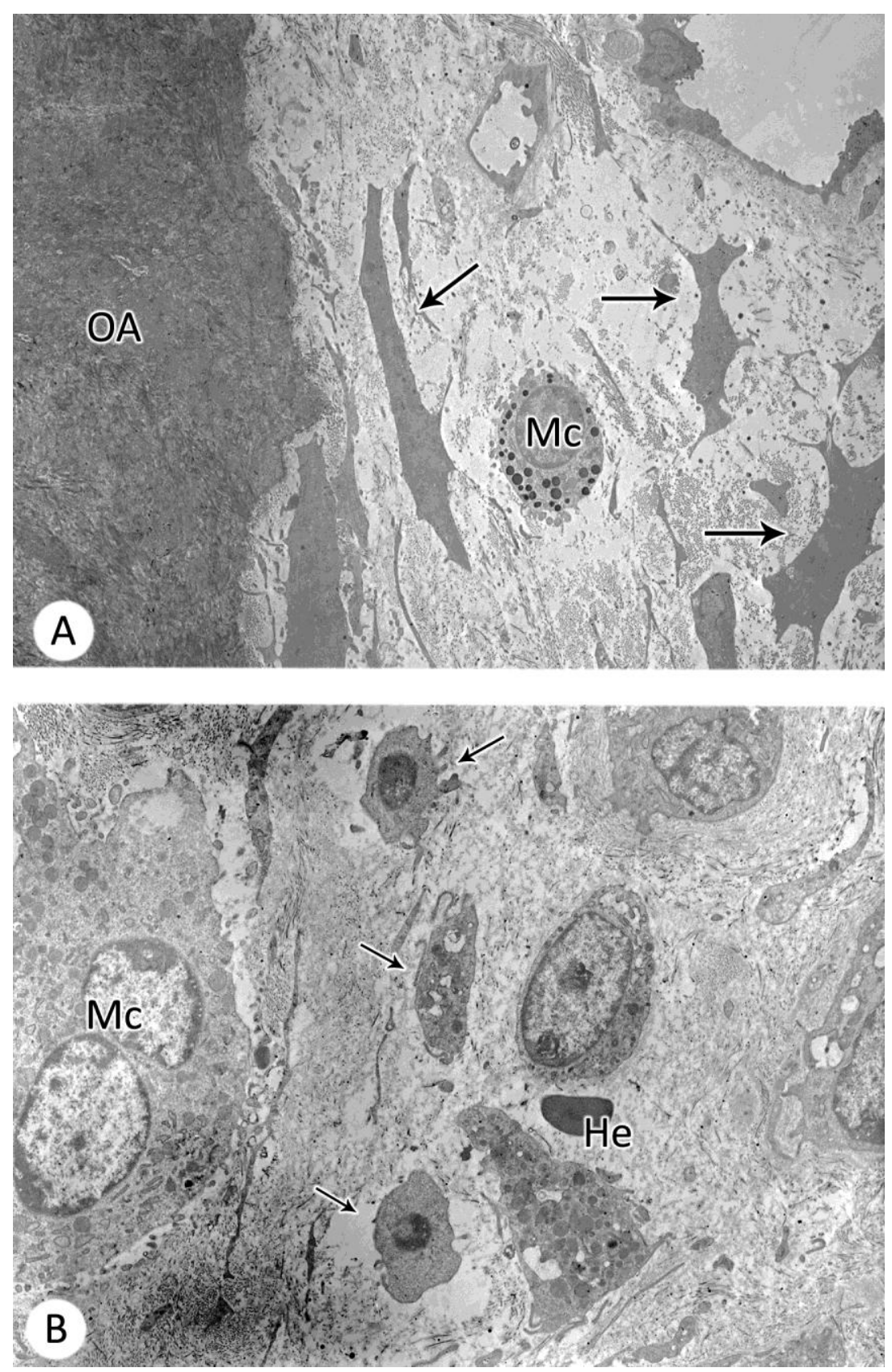
pressão, no entanto, a hialinização não atingiu todo o ligamento periodontal, encontrando-se também áreas de ligamento periodontal normal contendo fibrilas intactas e fibroblastos sem sinal de degeneração.

Em todos os espécimes analisados a superfície do cemento apresentouse sem sinais de reabsorção, com sua superfície lisa, fibras de Sharpey inseridas e cementoblastos adjacentes (Figura 10).

\subsection{Quinze dias de aplicação de força}

\subsection{1 Áreas de Tração}

Após quinze dias de movimentação as áreas de tração estavam localizadas em toda a extensão da face palatina da raiz vestibular e da face palatina da raiz palatina, como mostra o esquema 3 :

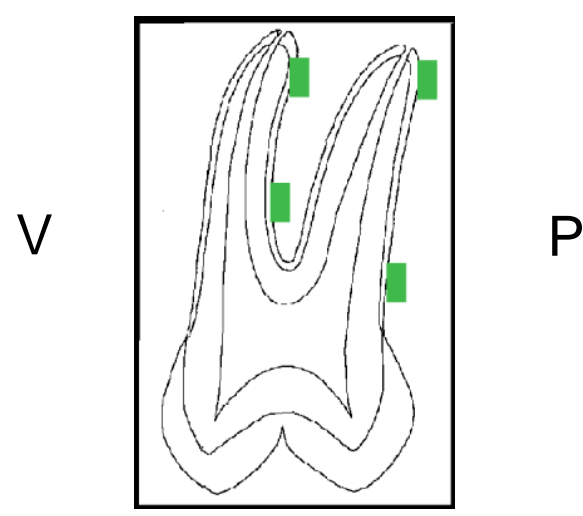

Esquema 3: áreas de tração, em verde.

As reações teciduais encontradas nessas áreas foram predominantemente de neoformação óssea. A matriz mineralizada recém sintetizada apresentou feixes de fibras colágenas desorganizados caracterizando um osso primário (novo) sintetizado rapidamente, encontrava-se em interface com osso lamelar (antigo) (Figura 11A). Os osteoblastos da superfície alveolar apresentavam grande quantidade de organelas de síntese 


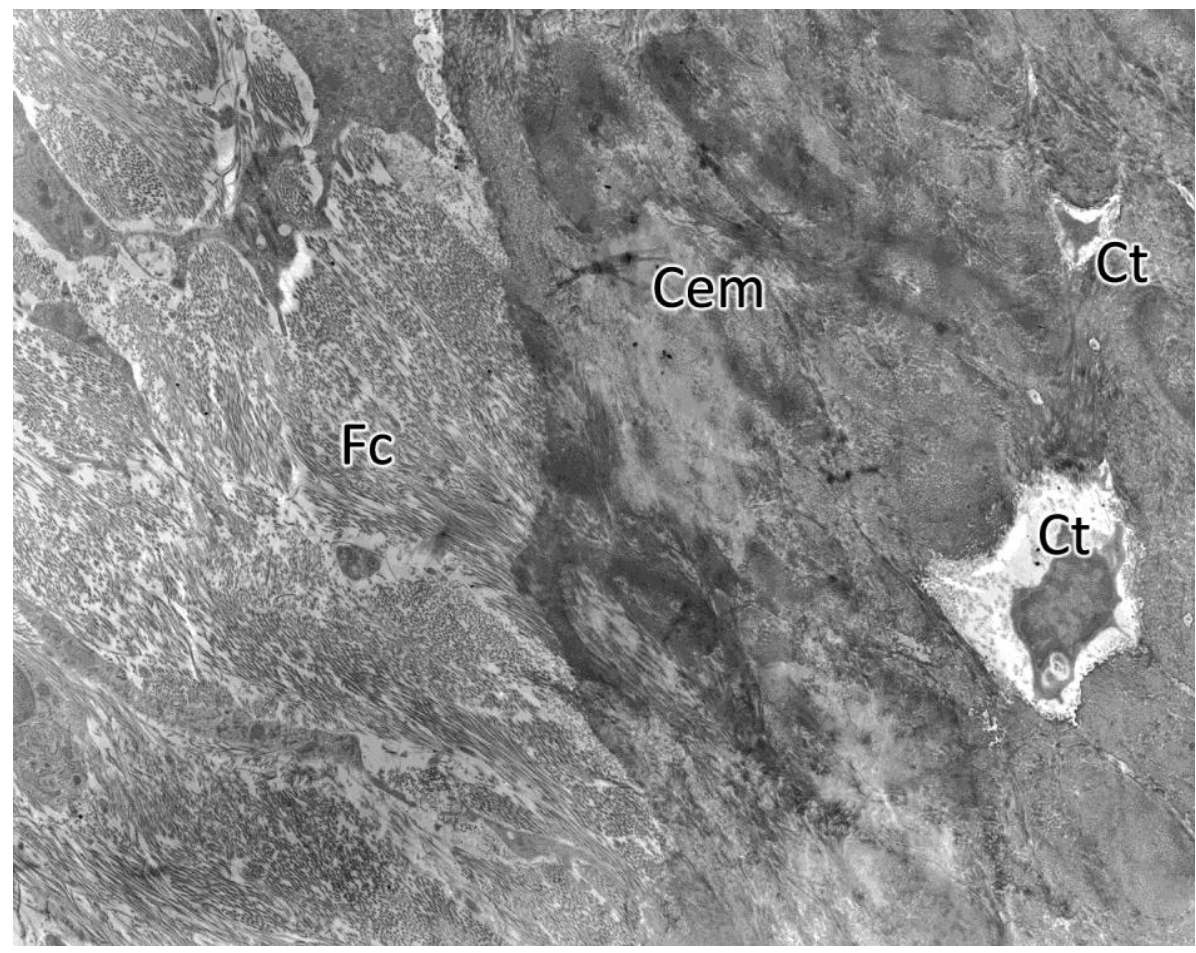



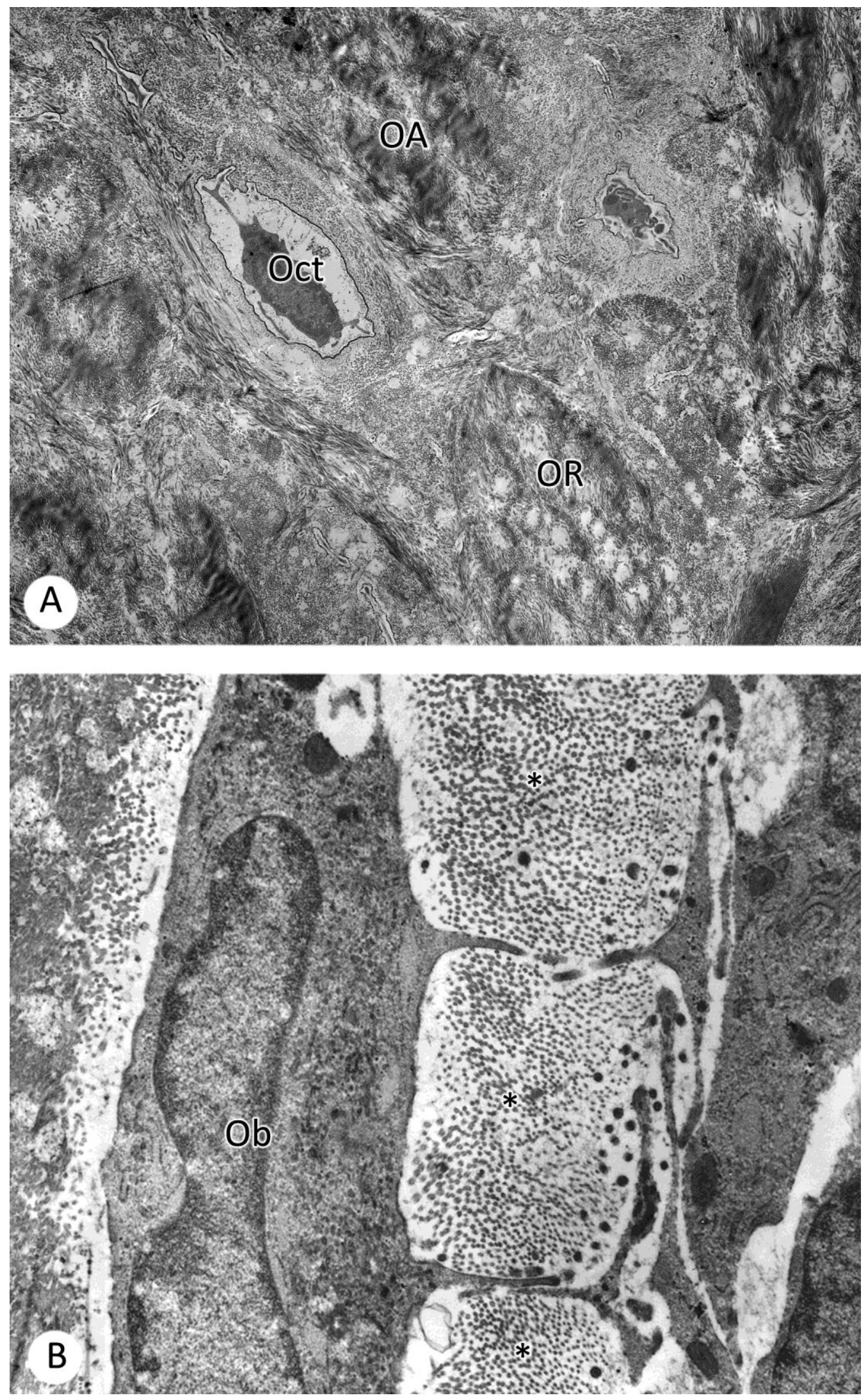
em seu citoplasma, revelando sua intensa atividade. Tais células foram vistas sobre uma camada de matriz óssea recém sintetizada não mineralizada (osteóide) (Figura 11B).

O ligamento periodontal apresentou algumas pequenas áreas hialinizadas, onde foi possível observar células em degeneração, hemácias dispersas pelo ligamento periodontal e alguns fibroblastos ativos (Figura 12).

O cemento apresentou-se na maioria das vezes sem sinais de reabsorção de sua superfície ou degeneração do interior da matriz, a qual apresentou cementócitos normais no interior de sua lacuna (Figura 13A). O terço cervical geralmente não foi reabsorvido devido à presença do cemento acelular e as fibras de Sharpey que nessa região se inserem protegendo a raiz e prevenindo a sobrecompressão (Figura 13B). Em algumas regiões, principalmente nos terços médio e apical, foi possível observar a reparação do cemento previamente reabsorvido. Clastos inativos saindo da superfície radicular foram encontrados, concomitantemente com a presença de células mononucleares e fibras de Sharpey (Figura 13C), além disso, em outras regiões havia cementoblastos adjacente ao cemento contendo em seu citoplasma retículo endoplasmático rugoso e complexo de Golgi e feixes de fibras colágenas (Figura 13D) demonstrando a reparação.

\subsection{2 Áreas de Pressão}

Após quinze dias de movimentação as áreas de pressão estavam localizadas em toda a extensão da face vestibular da raiz vestibular e da face vestibular da raiz palatina, como mostra o esquema 4 : 


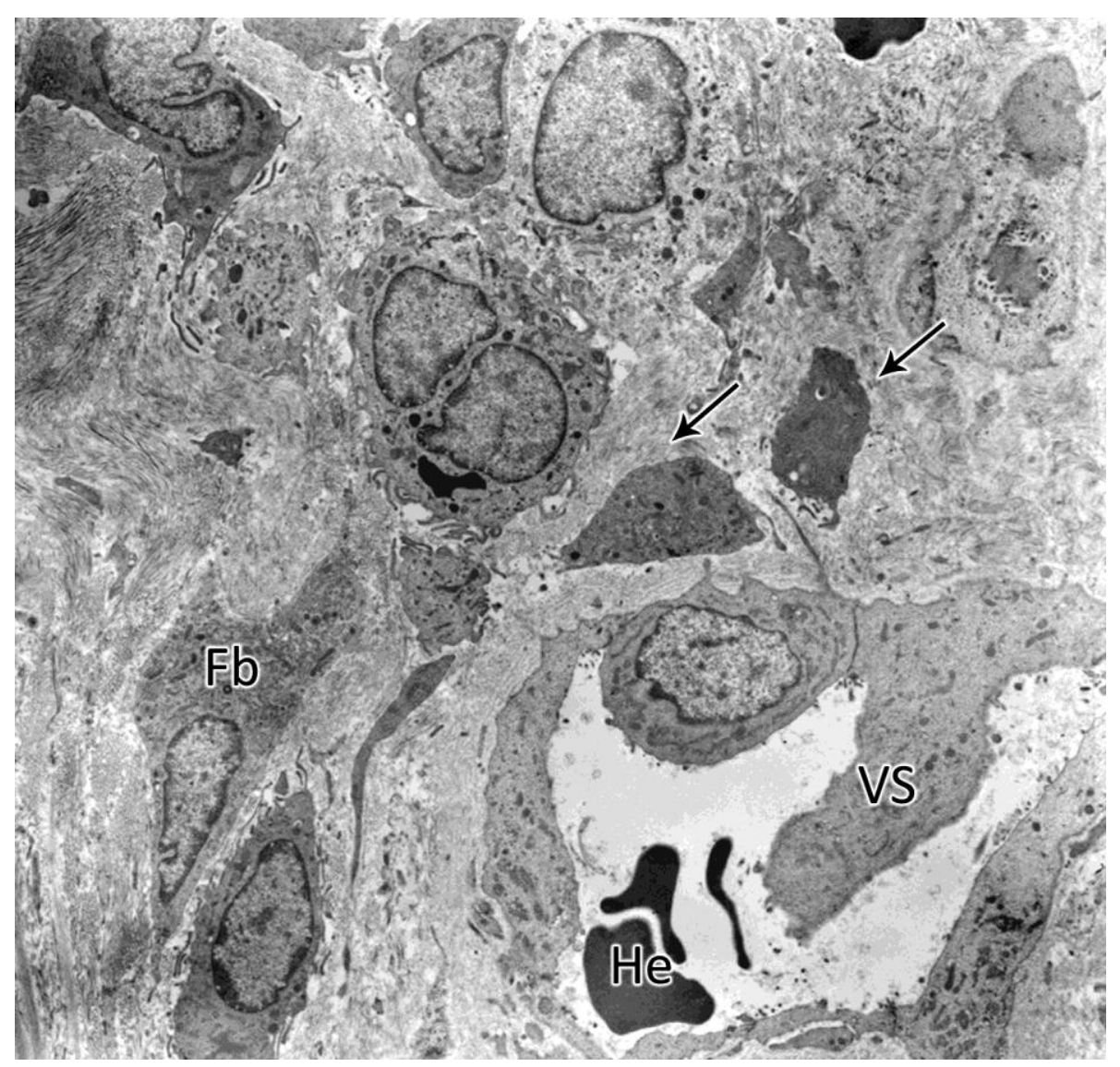



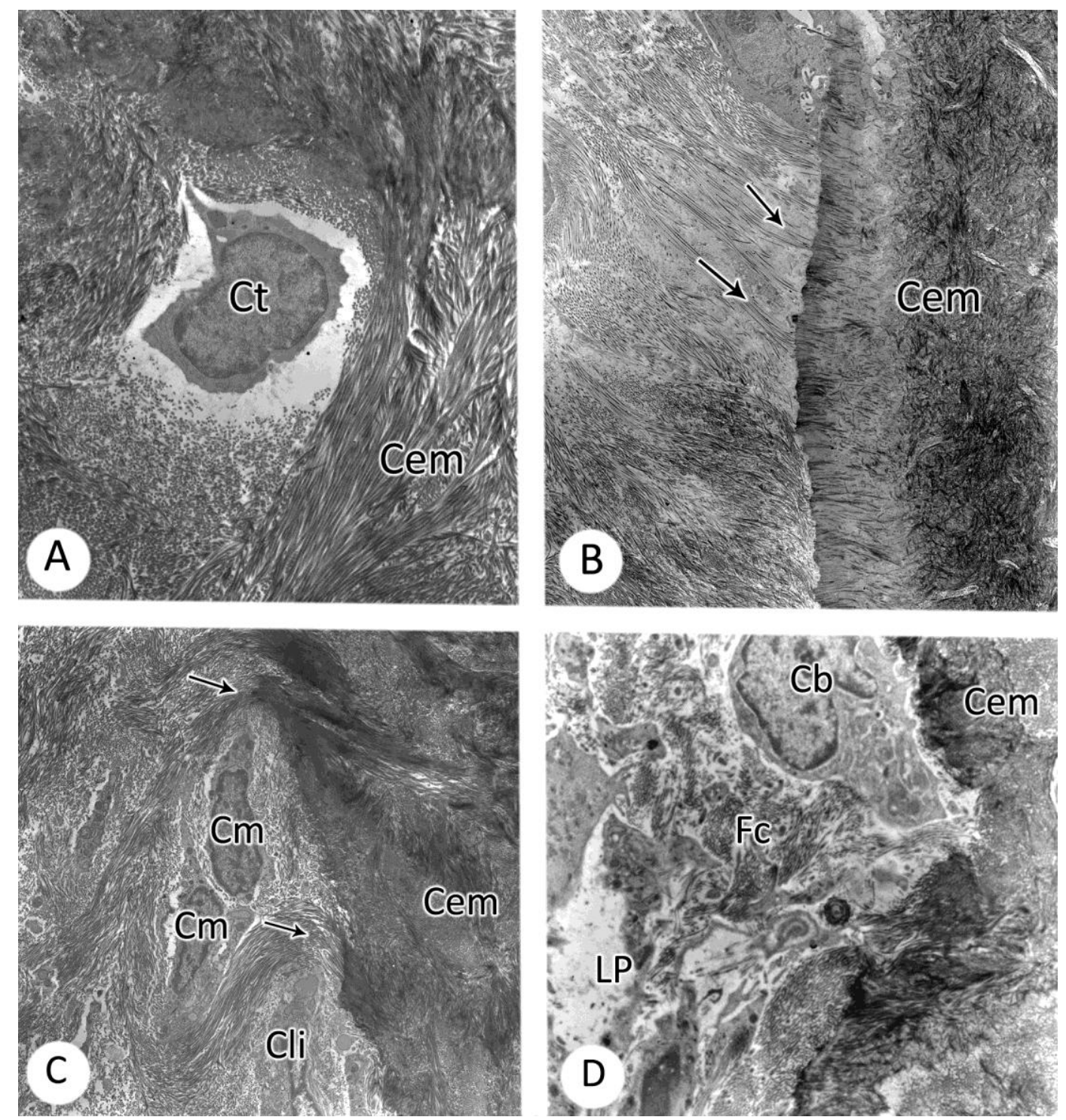


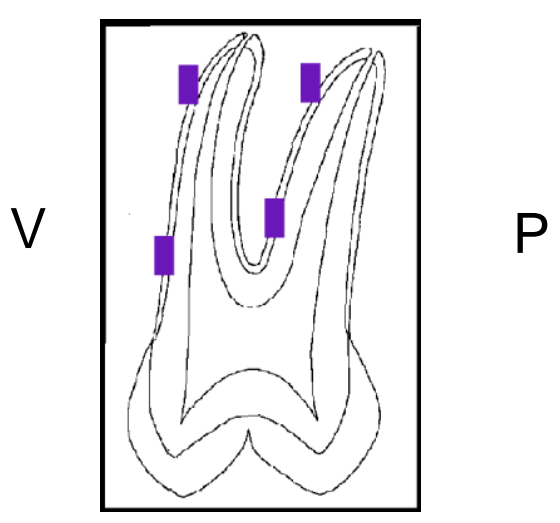

Esquema 4: áreas de pressão, em roxo.

Nas áreas de pressão houve predomínio de reabsorção óssea, contudo essas áreas também apresentaram neoformação óssea. Entretanto, esses não foram os únicos eventos presente nessas regiões, reabsorções radiculares foram encontradas nessas áreas. Em microscopia de luz foi possível observar muitos osteoclastos ativos aderidos à matriz óssea nas áreas de pressão; no entanto, células mononucleares também estavam presentes nessa região. Extensas áreas hialinizadas com aspecto homogêneo eram observadas no ligamento periodontal (Figura 14). Áreas onde foi possível encontrar células TRAP- positivas encontravam-se aderidas à raiz e alternavam-se com áreas em que o cemento apresentava-se intacto.

Como esperado, nas áreas de pressão foram encontrados muitos osteoclastos ativos aderidos à matriz mineralizada; entretanto, células mononucleares foram observadas adjacentes aos osteoclastos, evidenciando a reparação concomitante do osso (Figura 15A). Nas lacunas previamente reabsorvidas foi observada uma camada elétron-opaca na superfície e células mononucleares adjacentes (Figura 15B).

A hialinização foi um processo muito severo encontrado em diversas regiões do ligamento periodontal nas áreas de pressão e consistiu em um processo degenerativo das células do ligamento onde foi possível encontrar macrófagos (Figura 16A). Estas áreas foram tão extensas que ocupavam quase toda a extensão do ligamento periodontal desde o osso até o cemento, 
$\mathrm{OA}$

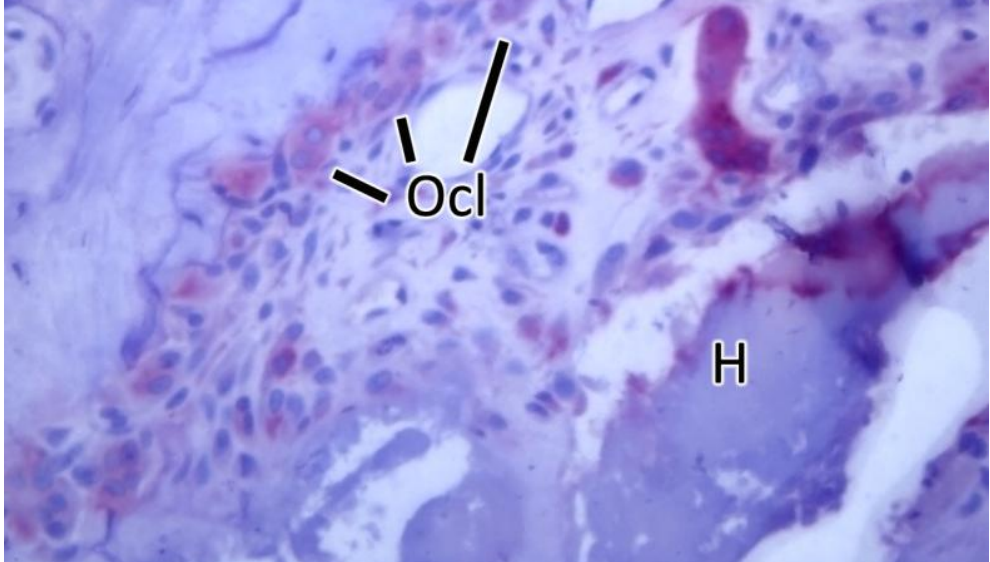



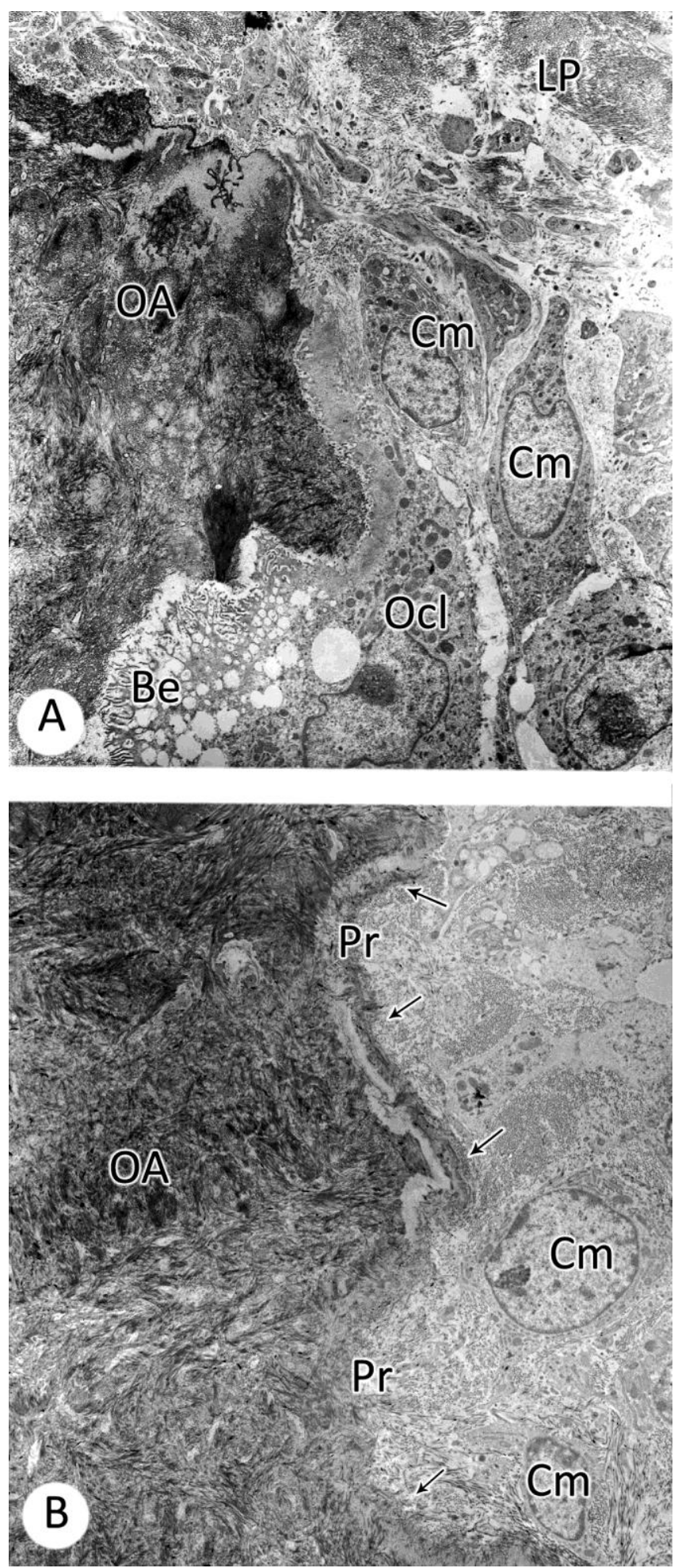

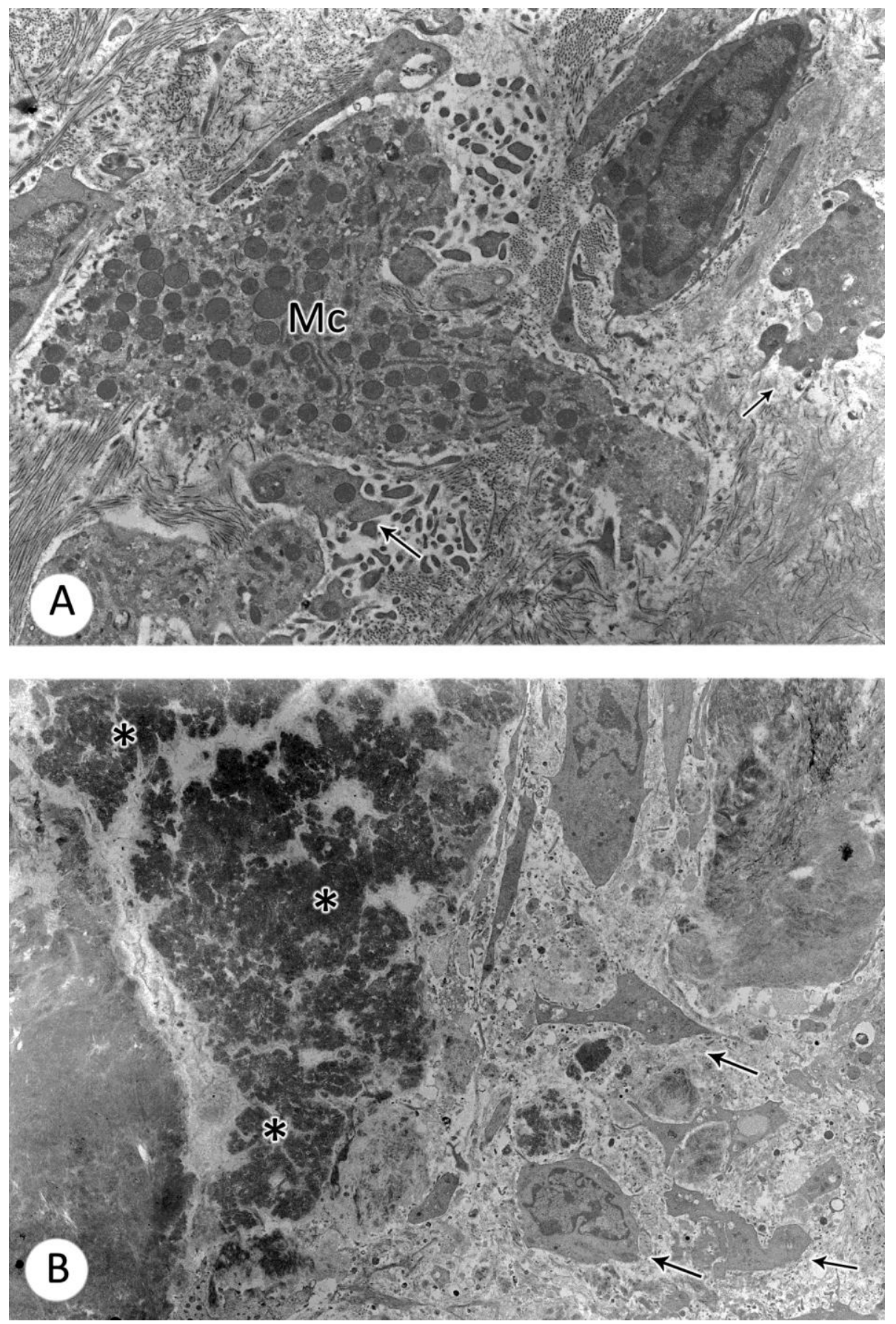
principalmente no terço cervical. Nos espécimes de 15 dias, essa reação foi mais intensa sendo possível observar um material em degeneração com aspecto granular e fortemente elétron-opaco. Nessas regiões não foi possível notar fragmentos celulares e matriz extracelular. (Figura 16 B). Nas áreas abaixo da hialinização o cemento apresentou-se normal, com superfície lisa e contínua, contendo fibras de Sharpey e cementoblastos (Figura 17A), no entanto, nas áreas adjacentes à hialinização (terço médio e apical) foi possível observar clastos ativos reabsorvendo o cemento (Figura 17B).

\subsection{Dezoito dias de aplicação de força}

\subsection{1 Áreas de Tração}

Após dezoito dias de movimentação as áreas de tração estavam localizadas nos mesmos locais em que foram observadas nos espécimes do grupo de quinze dias: em toda a extensão da face palatina da raiz vestibular e da face palatina da raiz palatina, como mostra o esquema 5 :

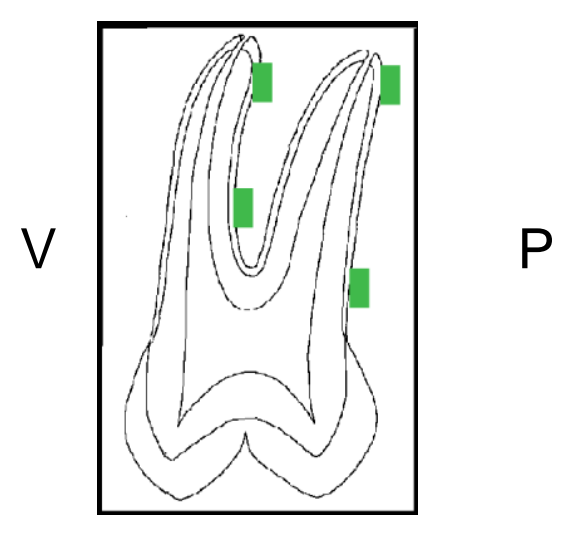

Esquema 5: áreas de tração, em verde.

As áreas de neoformação foram bem características em todos os tempos estudados, nas lacunas previamente reabsorvidas foram encontrados osteoblastos ativos sobre uma camada de matriz não mineralizada recém 

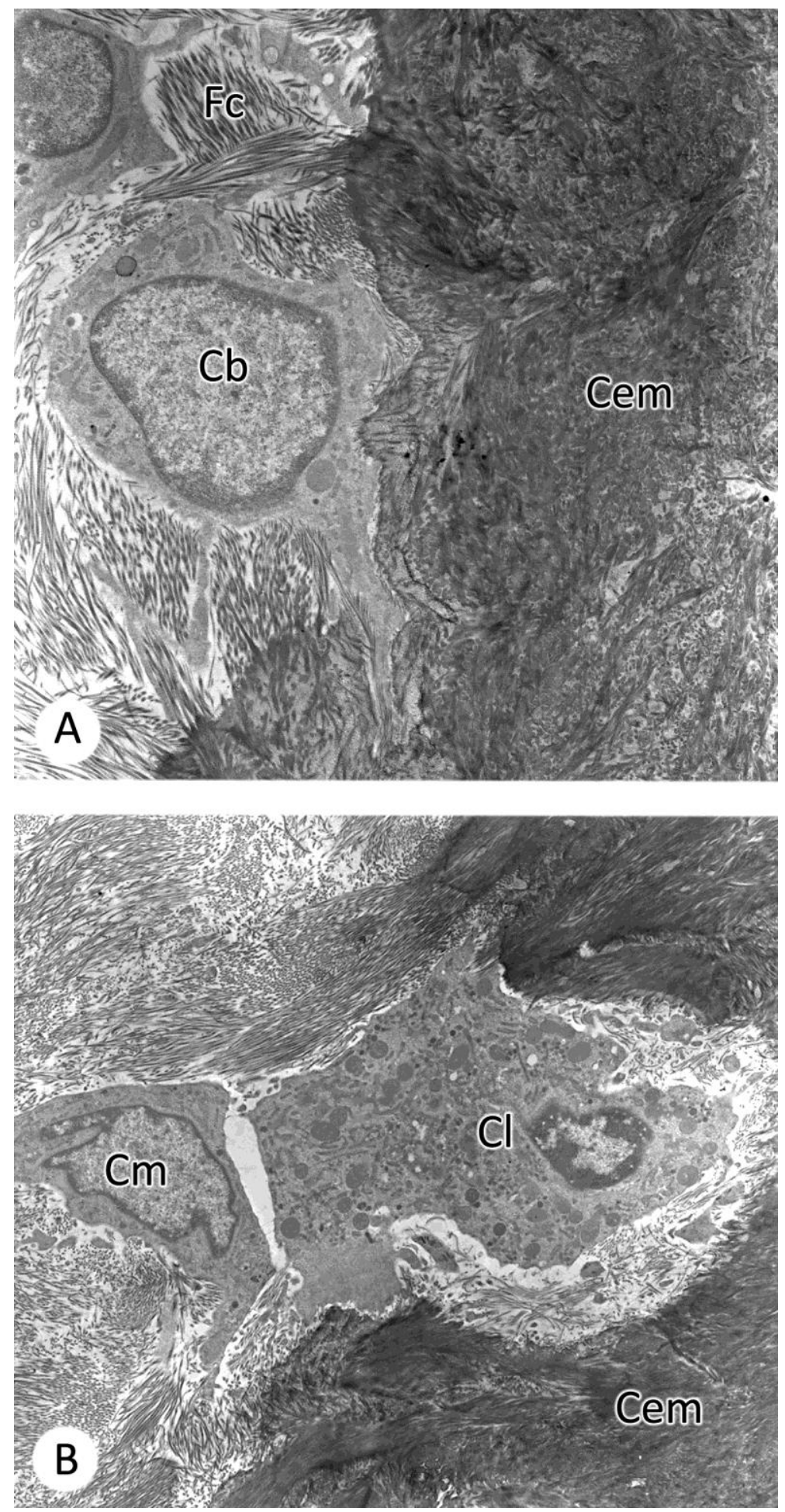
sintetizada (osteóide), a qual apresentava-se sobre uma matriz mineralizada com aspecto irregular, contendo fibras colágenas desorganizadas caracterizando um osso primário (Figura 18A).

O ligamento periodontal dessas regiões apresentou-se na maioria das vezes sem qualquer tipo de alteração, com fibroblastos e fibras colágenas constituindo feixes (Figura 18B). Na maioria das vezes, o cemento apresentou características normais, com presença de cementócitos dentro de suas lacunas e fibras de Sharpey. No entanto, nas regiões onde houve pequena reabsorção do cemento, foi possível observar o tecido de reparação, cementoblastos adjacentes e fibrilas colágenas (Figura 18C).

\subsection{2 Áreas de Pressão}

Após dezoito dias de movimentação as áreas de pressão estavam localizadas nos mesmos locais em que foram observadas nos espécimes do grupo de quinze dias: em toda a extensão da face vestibular da raiz vestibular e da face vestibular da raiz palatina, como mostra o esquema 6 :

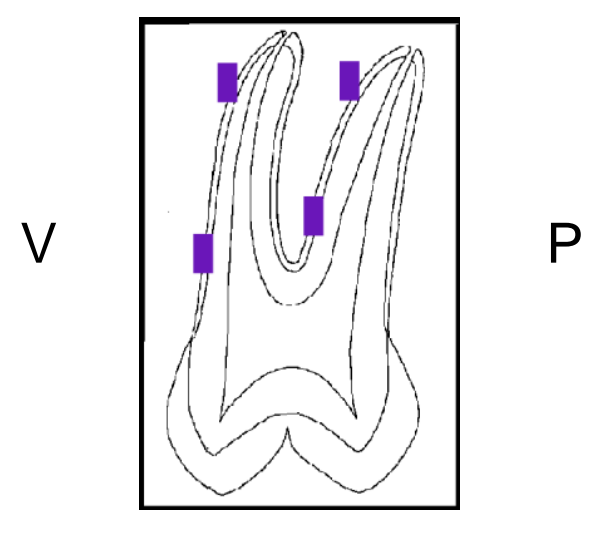

Esquema 6: áreas de pressão, em roxo.

Como já foi citado nos tempos anteriores, as áreas de pressão apresentaram predomínio de reabsorção óssea. Em microscopia de luz osteoclastos foram encontrados aderidos à superfície óssea, áreas hialinizadas 

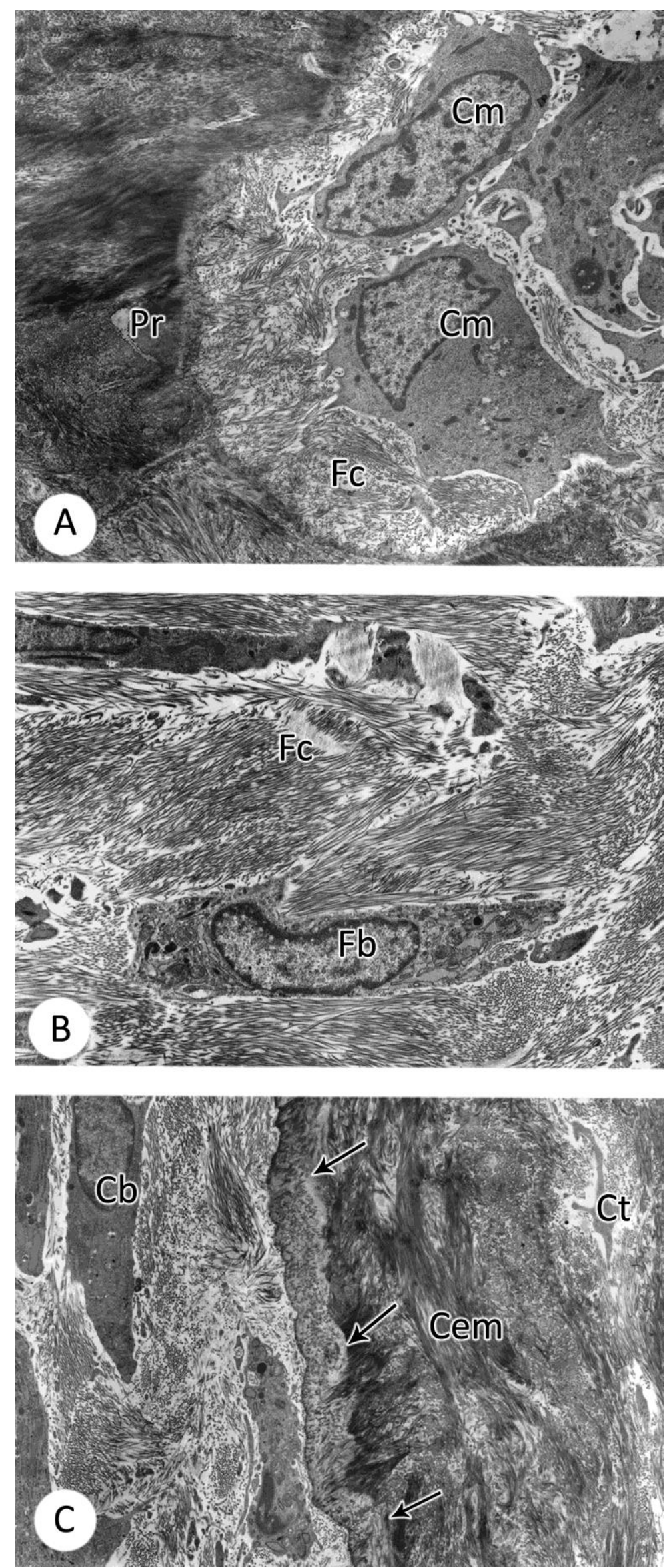
dispersas em todo o ligamento periodontal e células clásticas TRAP positivas reabsorvendo a raiz (Figura 19).

Foi possível observar a presença de osteoclastos inativos, que puderam ser observados a certa distância da matriz óssea, deixando exposta a matriz mineralizada, cuja superfície apresentou-se como lacuna previamente reabsorvida. Tais concavidades apresentavam células mononucleares nas proximidades e matriz orgânica não mineralizada (osteóide) entre elas (Figura 20A). A hialinização foi encontrada em todos os espécimes analisados nas áreas de pressão do ligamento periodontal. Porém, sua severidade foi menor do que nos espécimes de quinze dias e não ocupava toda a sua extensão; estava localizada principalmente no $1 / 3$ cervical. Além disso, foi possível observar restos celulares, hemácias e macrófagos dispersos pelo ligamento periodontal (Figura 20B).

Com a manutenção da força por dezoito dias algumas regiões da raiz apresentaram-se reabsorvidas. A reabsorção nesse período foi tão intensa que atingiu a dentina. Clastos ativos, com zona clara e borda em escova bem desenvolvida, foram encontrados aderidos à dentina e o ligamento apresentouse hialinizado. (Figura 21A). No entanto, em algumas dessas áreas foi possível observar o início de reparação, com a presença de cementoblastos entre osteoclastos inativos e a dentina previamente reabsorvida (Figura 21B).

\subsection{Imunocitoquímica para OPN}

Como descrito na análise morfológica ultra-estrutural, o processo de remodelação do osso alveolar estimulado pela força ortodôntica contínua ocorreu nos três grupos estudados, apresentando características comuns importantes. Além disso, nos dois últimos tempos estudados, apareceram áreas de reabsorção radicular e de reparação. Assim, os resultados da análise imunocitoquímica da proteína osteopontina (OPN), serão descritos levando em consideração a presença e distribuição da OPN durante a movimentação dentária estimulada pela força ortodôntica contínua de $15 \mathrm{cN}$. 


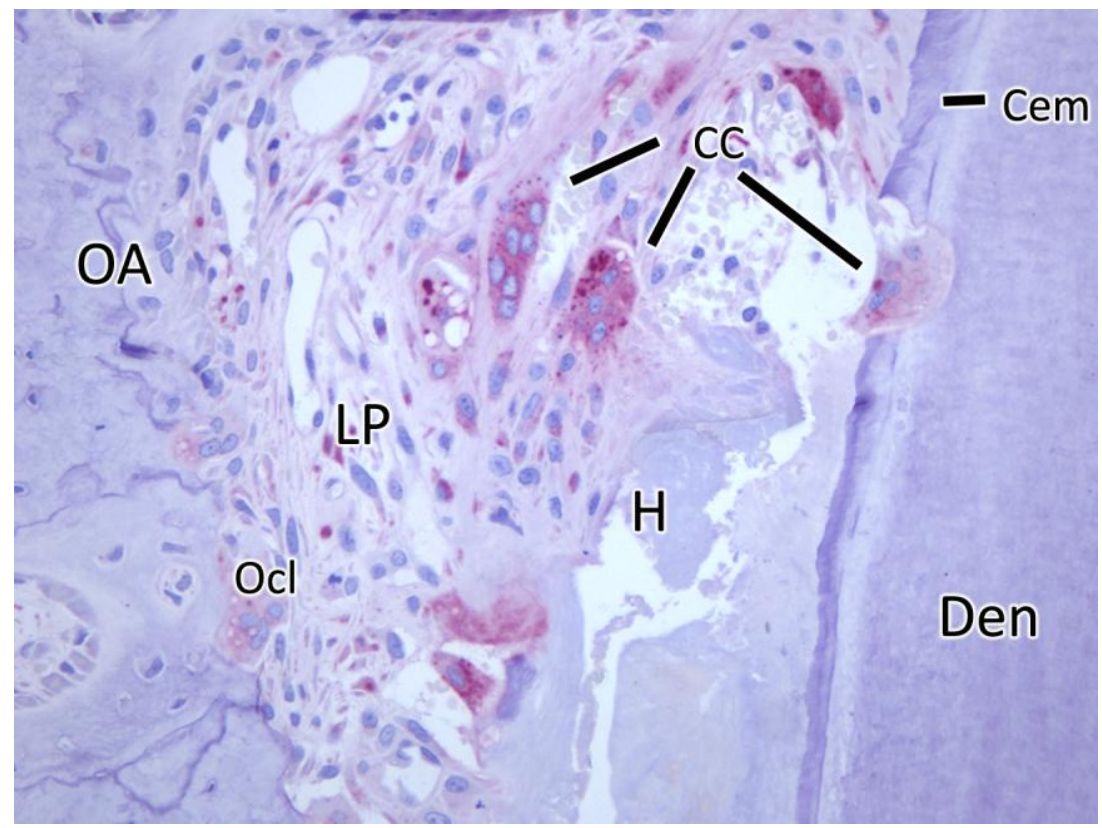



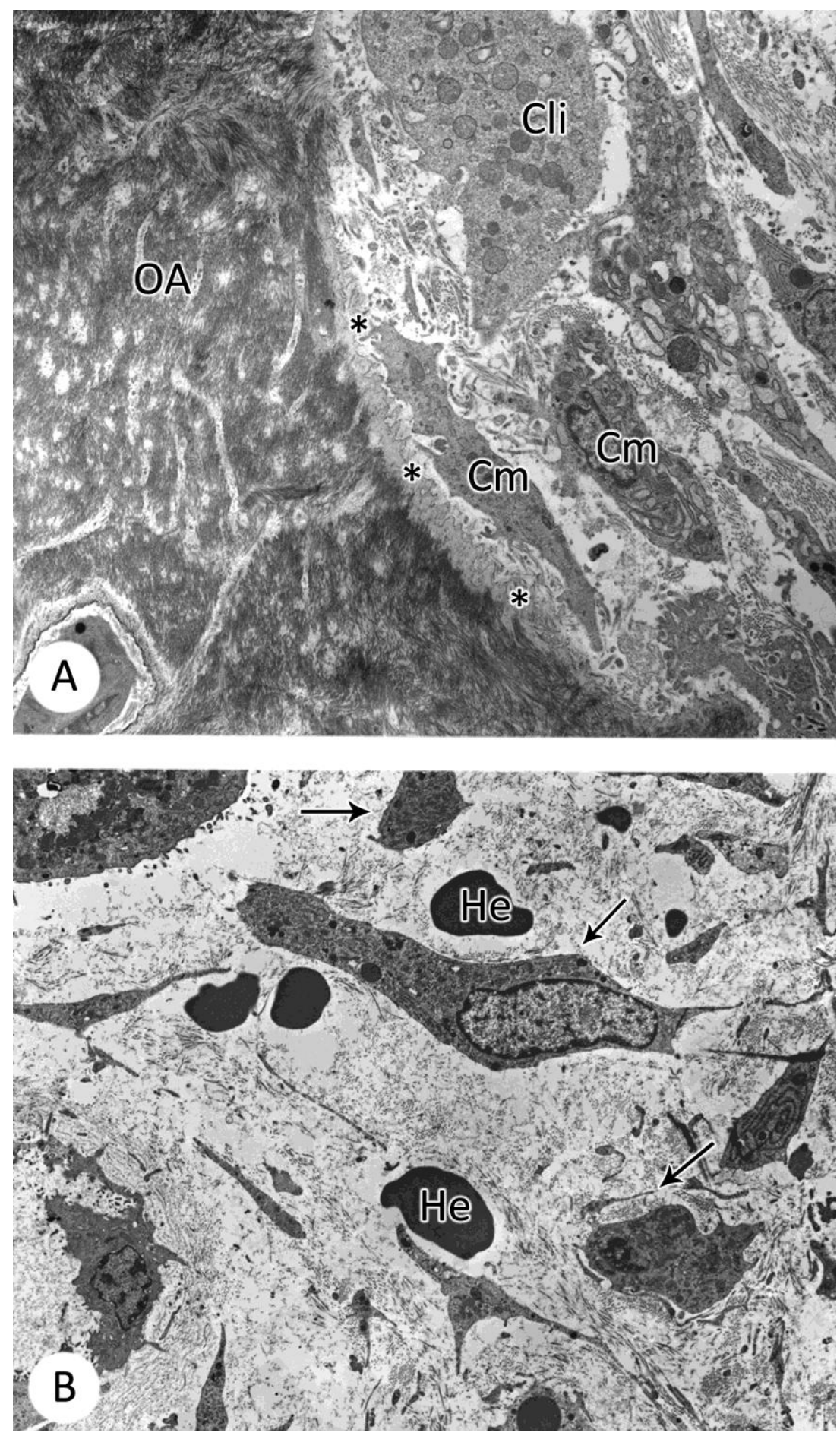

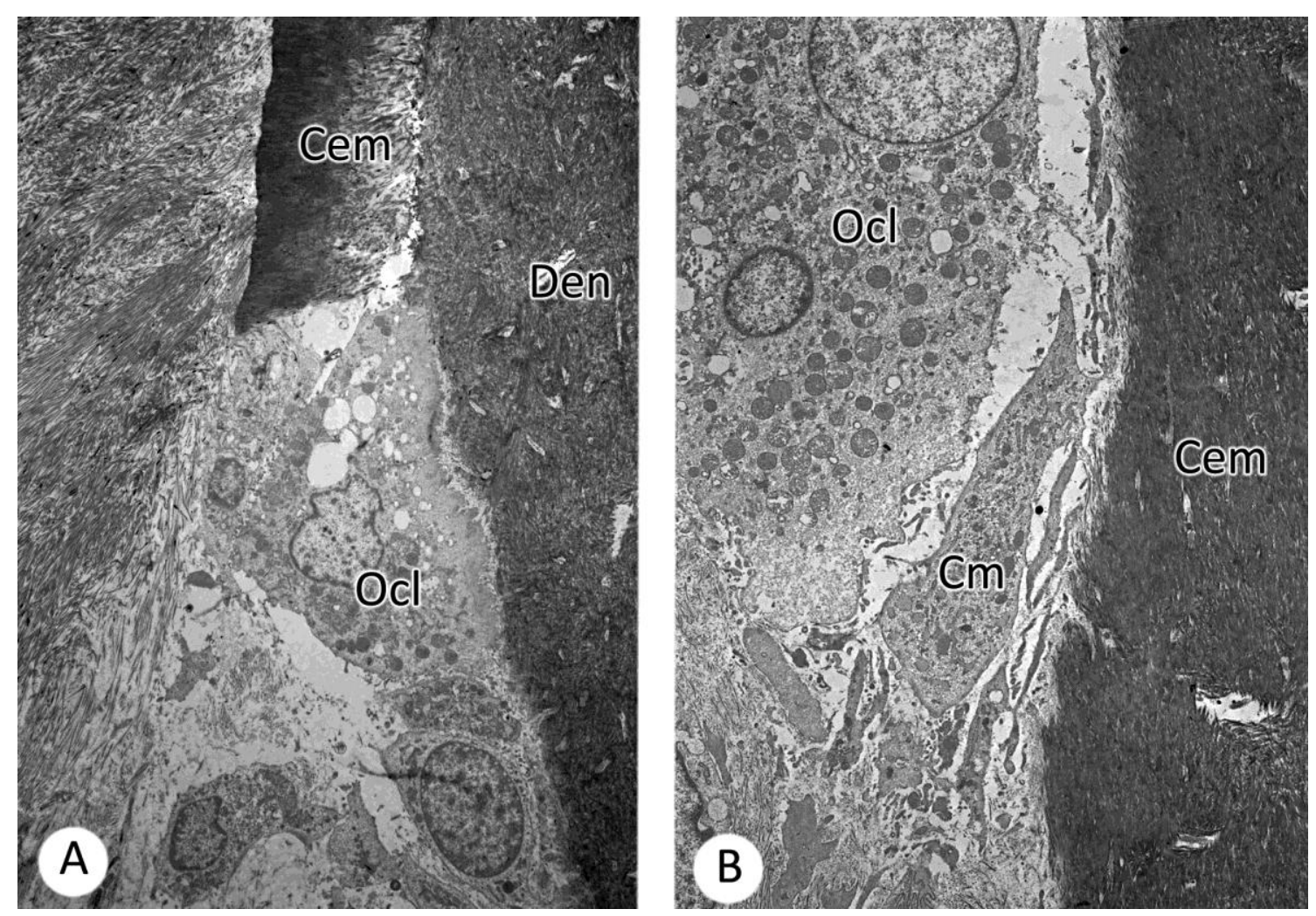
Os osteoclastos ativos não apresentaram marcações positivas para OPN no interior do seu citoplasma (Figura 22A). No presente estudo, não foi observada a presença de OPN sob a zona clara de osteoclastos ativos em nenhum dos tempos estudados. Em alguns espécimes foi possível observar linhas cimentante com marcação positiva para OPN e adjacente a ela osteoclasto reabsorvendo essa matriz mineralizada (Figura 22B). Nas áreas onde havia osteoblastos ativos justapostos à superfície alveolar, as camadas elétron-opacas observadas na análise morfológica apresentaram-se fortemente marcadas para OPN. Tais estruturas apresentavam-se no interior da matriz mineralizada formando uma linha cimentantes espessas. (Figura 23A). Embora essas camadas espessas, marcadas por OPN, tenham sido freqüentemente observadas, no entanto, não foram encontradas em toda a extensão da superfície alveolar.

Conforme mencionado anteriormente, a espessura das linhas cimentantes geradas frente ao estímulo ortodôntico, foi maior do que a espessura de uma linha cimentante gerada frente a uma remodelação fisiológica sem indução, observada nos espécimes do grupo controle (Figura 23B). O interior da matriz mineralizada apresentou acúmulos de proteínas não colágenas entre as fibras colágenas, aspecto normal da matriz do tecido ósseo.

$\mathrm{Na}$ superfície radicular (cemento) foi possível observar a marcação positiva para OPN, sendo que diversas partículas de ouro foram encontradas espalhadas por toda a superfície no grupo controle (Figura 24). Nos grupos movimentados existiram áreas que em houve reabsorção radicular e áreas que estas não foram observadas. Nas áreas em que a reabsorção não ocorreu foi possível observar marcação positiva para OPN (Figura 25A), no entanto, as áreas em que houve reabsorção radicular, as bordas das lacunas apresentaram intensa marcação para OPN (Figura 25B).

Nas áreas onde estava ocorrendo reparação, células mononucleadas foram observadas justapostas sobre a superfície do cemento, a qual apresentava imunoreatividade para OPN. Nestas áreas foi possível encontrar 

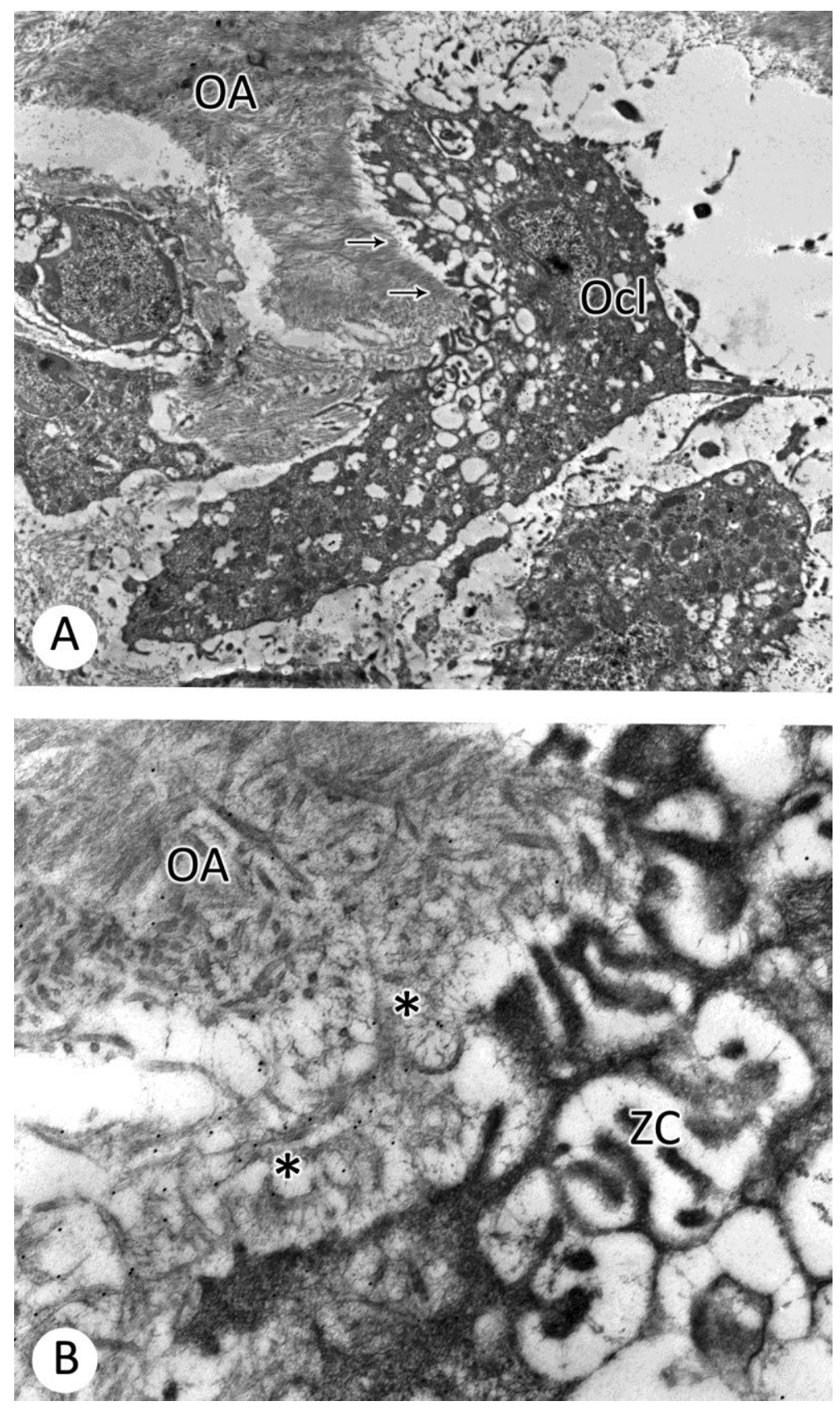

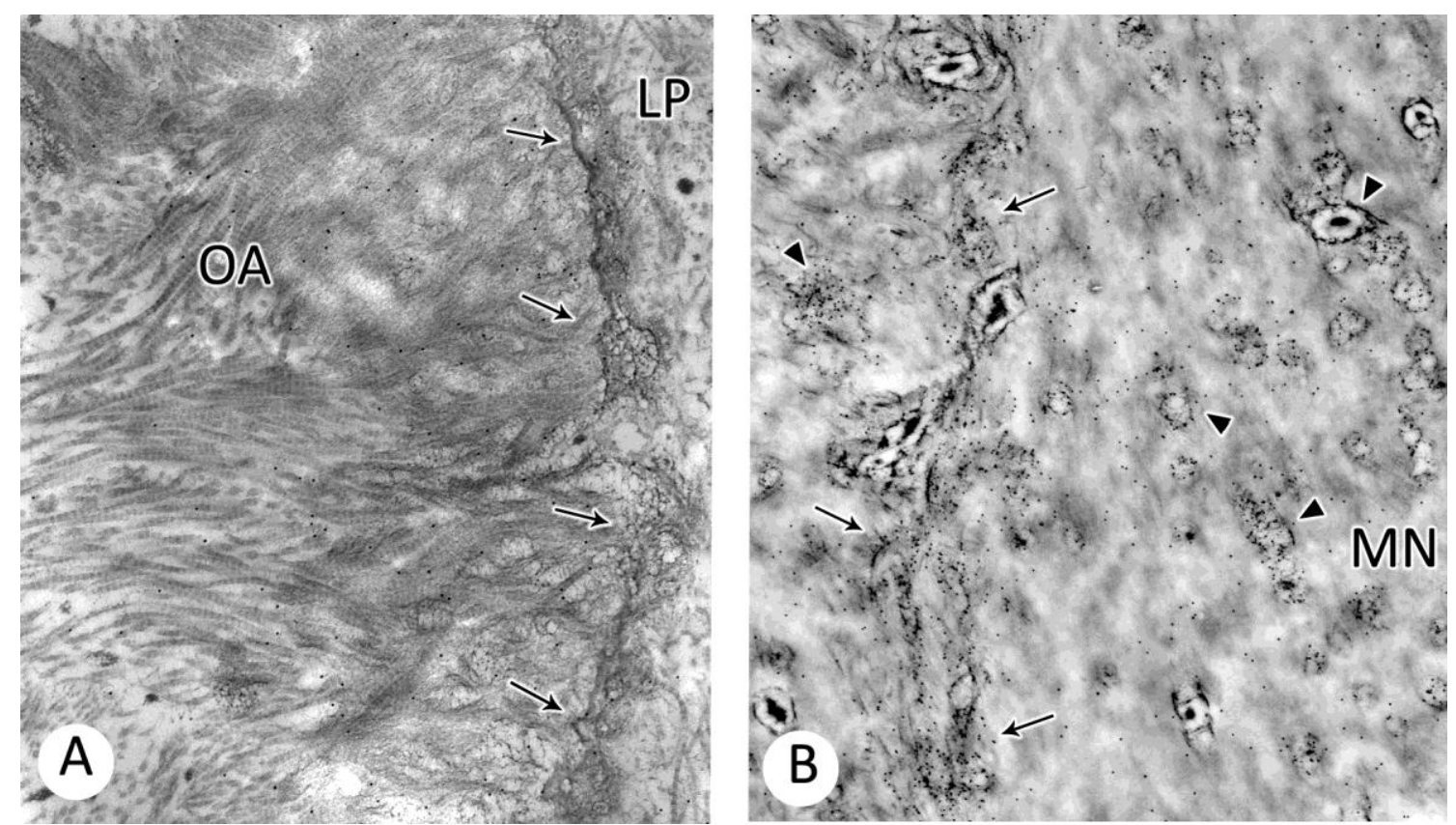


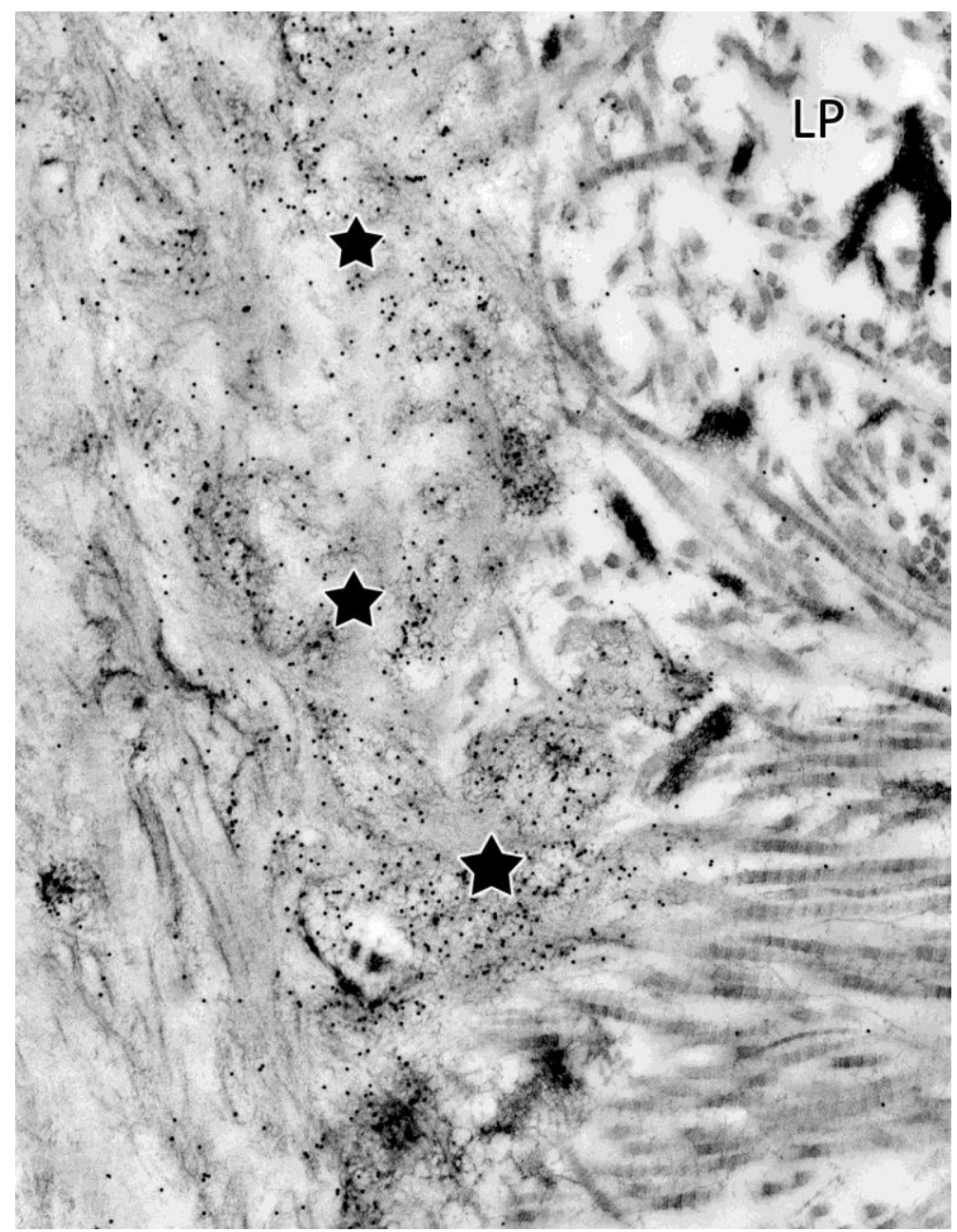



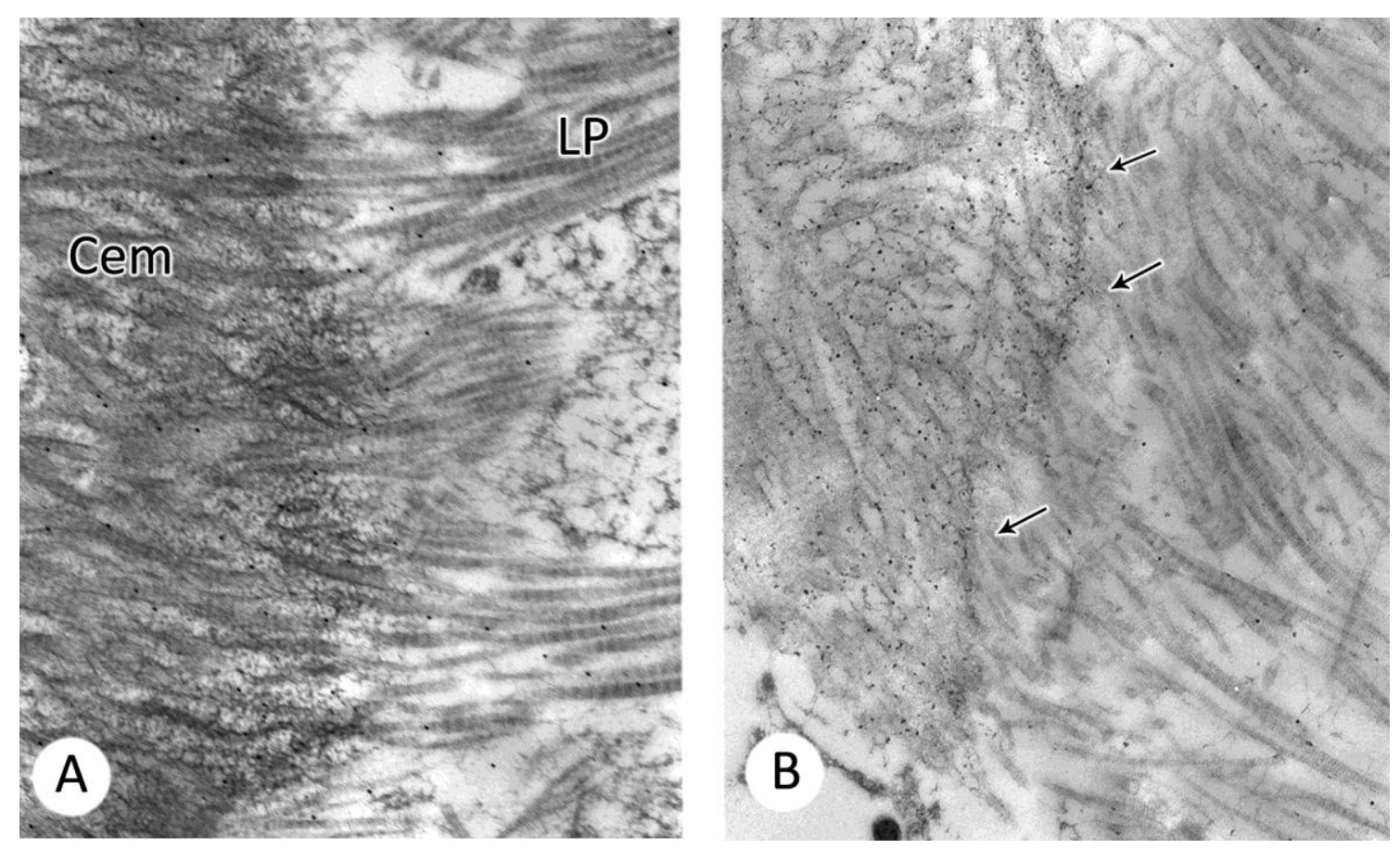

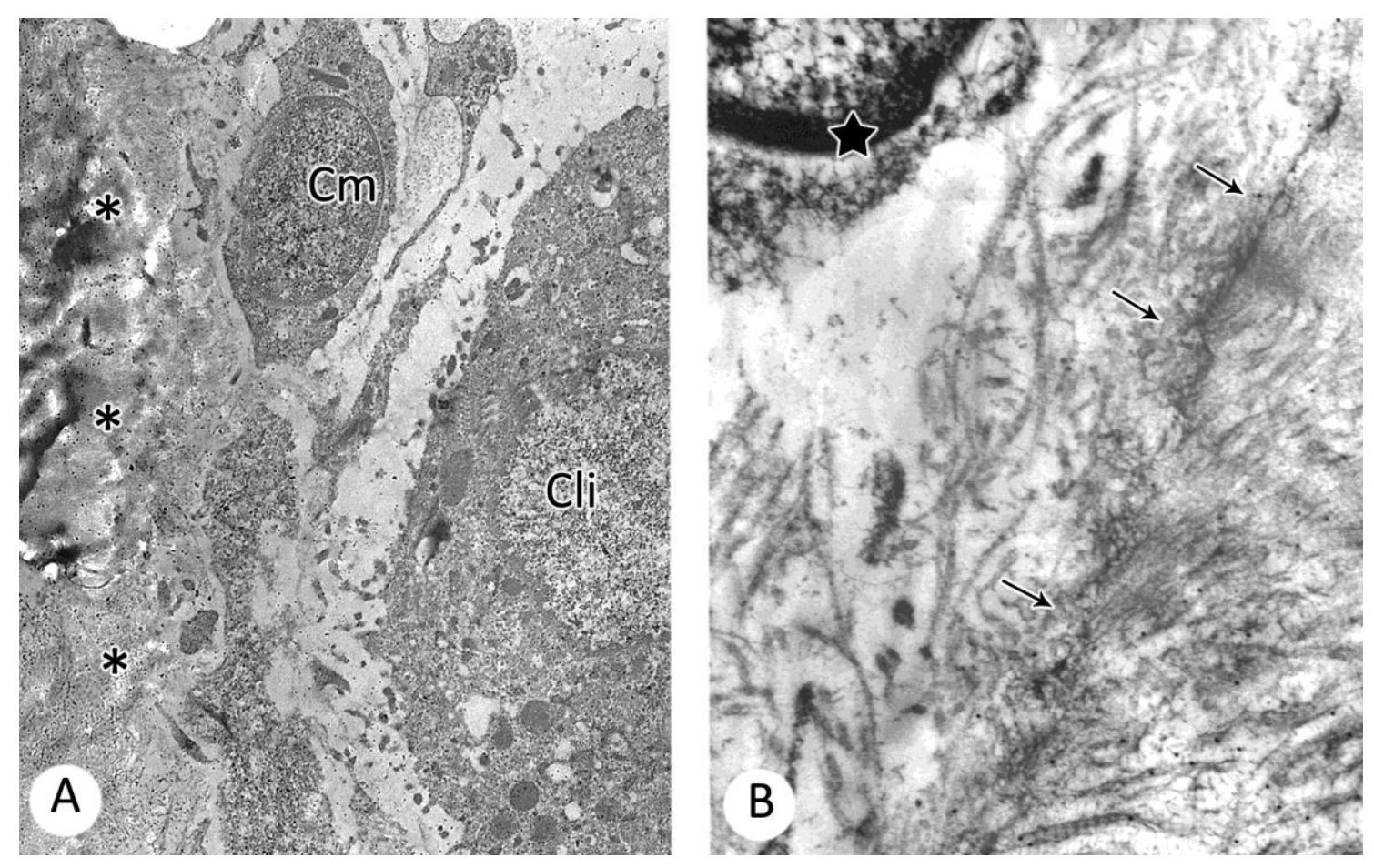
osteoclastos inativos, deixando a superfície do cemento (Figura 26A). Além disso, linhas cimentantes marcadas por OPN foram encontradas no interior da matriz mineralizada (Figura 26B). Em todos os espécimes analisados, a presença de células mononucleadas adjacentes às camadas e linhas marcadas foi constante.

É importante salientar que a reação imunocitoquímica para OPN realizada no presente estudo apresentou grande especificidade, uma vez que não foi encontrada qualquer marcação positiva nas fibras colágenas do ligamento periodontal adjacente. 
6 DISCUSSÃO 
O presente estudo mostrou que a aplicação de uma força ortodôntica "fisiológica" e contínua em molares de ratos provoca alterações no osso alveolar e no ligamento periodontal, gerando áreas de hialinização, principalmente no lado de pressão, mas também no lado de tração. Além disso, gera numerosas áreas de reabsorção radicular, as quais estão localizadas em áreas de pressão, sendo que sua extensão e severidade estão diretamente relacionadas com a duração da aplicação da força. A imunolocalização da proteína osteopontina mostrou sua presença em grandes quantidades nas superfícies ósseas e radiculares previamente reabsorvidas. Nessas áreas, a espessura das linhas cimentantes foi muito maior do que as formadas durante a remodelação fisiológica.

O estudo das respostas teciduais frente à movimentação ortodôntica em pequenos animais tem como obstáculo o tamanho das estruturas envolvidas na movimentação dentária, as quais por serem muito pequenas dificultam na elaboração de uma mecânica precisa; portanto, a maioria dos trabalhos utiliza elásticos interproximais (TERAl et al. 1999) ou mola de secção fechada (MAVRAGANI et al., 2004; JÄGER et al., 2008). Além disso, nestes trabalhos utilizando essa biomecânica, o tipo de movimento encontrado é a mesialização do primeiro molar superior, um tipo de movimento que, pela anatomia das raízes desse dente é pouco comparável com as movimentações em humanos. A biomecânica utilizada no presente estudo provou ser eficiente, transmitindo uma força contínua precisa de $15 \mathrm{cN}$, de vestibularização sobre os molares de ratos (BONAFE-OLIVEIRA et al., 2003).

O presente estudo utiliza o termo "tempos prolongados" em relação ao trabalho anterior que utilizou o mesmo modelo (BONAFE-OLIVEIRA, 2006). Apesar de dezoito dias ser um tempo relativamente curto para ser chamando de prolongado, no entanto, devido à erupção contínua do incisivo do rato esse é o tempo máximo que a biomecânica permanece instalada.

Muitos estudos indicam que a hialinização em zonas de pressão do ligamento periodontal é quase inevitável (REITAN, 1957; RYGH, 1995). A hialinização é uma área onde há sobrecompressão do ligamento periodontal, ocorrendo uma necrose asséptica em áreas localizadas devido à 
movimentação ortodôntica, sendo um fator grau limitante da mesma (RYGH, 1974).

Após 12 dias de movimentação (período inicial) foram encontradas regiões de hialinização nas áreas de pressão, no entanto, com tempos maiores, as regiões hialinizadas se tornaram mais extensas e severas nas áreas de pressão. Em todos esses períodos foi observada a presença de macrófagos, células específicas para a remoção dos restos celulares. Já nos grupos de 15 e 18 dias, a matriz apresentava-se em degeneração com aspecto granular e fortemente elétron-opaco. Nessas regiões não foi possível notar fragmentos celulares e matriz extracelular.

Nos espécimes dos grupos de 15 e 18 dias, as áreas de pressão estavam localizadas em toda a extensão da face vestibular da raiz vestibular e da face vestibular da raiz palatina e as áreas de tração estavam localizadas em toda a extensão da face palatina da raiz vestibular e da face palatina da raiz palatina, havendo uma mudança na localização dessas áreas quando comparado com o período inicial do estudo, onde as áreas de pressão estavam localizadas no terço apical da face vestibular da raiz vestibular, terço cervical da face palatina da raiz vestibular, terço apical da face vestibular da raiz palatina, terço cervical da face palatina da raiz palatina.

Nas áreas hialinizadas não há o recrutamento dos precursores de osteoclastos, e nem a fusão e ativação dos osteoclastos, portanto a remodelação óssea não ocorre. Com isso a movimentação dentária pára até que o osso alveolar seja reabsorvido e a hialinização removida e a área é repopulada por células (REITAN, 2005). Como a hialinização limita a movimentação dentária, pode se dizer que a partir do $15^{\circ}$ dia a movimentação dentária foi paralizada ocorrendo esta mudança de localização das áreas de pressão e tração. Bonafe-Oliveira et al. (2003) encontraram um tipo de movimento chamado de inclinação controlada, ou seja, a raiz acompanha o movimento da coroa (VERNA et AL., 2000; SMITH e BUSRTONE, 1984). 
Para entender este tipo de movimento, precisamos conhecer a biomecânica do movimento dentário. $O$ dente possui um centro de resistência, que é o local onde uma força aplicada produz um movimento de deslocamento ou de "corpo". No entanto, o centro de resistência encontra-se na porção radicular, portanto, a força aplicada está longe do centro de resistência. Desse modo, há tendência de ocorrer inclinação e rotação, ou seja, a coroa deslocarse para o lado do sentido da força e a raiz para o lado oposto. O potencial para que um dente sofra rotação é chamado de momento e é medido como o produto da força aplicada e da distância entre o ponto de aplicação da mesma e o centro de resistência. Quanto maior o momento, maior o potencial de rotação. No presente estudo, realizado em ratos, que apresenta estruturas dentais e periodontais muito pequenas, a força aplicada na coroa foi muito próxima do centro de resistência, e com isso o momento foi muito pequeno, portanto, o potencial de rotação foi diminuído.

No movimento de inclinação controlada as áreas de pressão e tração se alternam conforme o tempo, ou seja, os eventos observados com 3 dias se repetem aos 7 dias; da mesma maneira que os eventos ocorridos aos 5 dias se repetem aos 10 dias (BONAFE-OLIVEIRA, 2006). No presente estudo, no período inicial (12 dias) foram encontradas respostas semelhantes ao $3^{\circ} \mathrm{e}$ $7^{\circ}$ dia. Já nos períodos intermediário e final houve uma mudança na localização das áreas de pressão, conforme sugerido anteriormente, devido a paralização da movimentação ortodôntica.

As reabsorções radiculares foram encontradas a partir do $15^{\circ}$ dia de movimentação dentária. Estas eram muito extensas, atingindo a dentina, mesmo com a utilização de uma força "fisiológica". Podemos dizer que a força é fisiológica uma vez que reações apresentadas no trabalho de Bonafe-Oliveira (2006), e no primeiro período deste trabalho não foram muito severas, permitindo a reorganização dos tecidos periodontais. Embora a força seja considerada fisiológica, essa é a primeira vez que é observada reabsorção radicular. A reabsorção é atribuída à quantidade de tempo que a biomecânica permanece instalada, uma vez que a reabsorção foi mais severa, atingindo a 
dentina quanto maior foi o tempo de aplicação da força. Existem muitos trabalhos relacionando a quantidade de força aplicada com a quantidade de reabsorção radicular concluindo que quanto maior a força maior a reabsorção (FALTIN et al., 2001; CASA et al., 2001). Entretanto, outros trabalhos não evidenciaram aumento significativo da reabsorção radicular quando a força foi aumentada excessivamente (OWMAN-MOLL et al., 1996a,b).

Os achados deste trabalho mostram que a quantidade de reabsorção radicular aumenta com o tempo e está de acordo com outros trabalhos (KUROL et al., 1996). Mavragani et al, mostraram em ratos que as lacunas de reabsorção radiculares se tornam mais profundas quanto maior o tempo de aplicação de força. Alguns autores, no entanto, não encontraram associação entre o tempo e a quantidade de reabsorção (LILJA e ODENRICK, 1982; OHM e LINGE 1982). No período inicial deste trabalho nenhuma área de reabsorção foi observada no cemento, com o aumento do tempo a reabsorção passou a existir e foi se tornando mais severa atingindo a dentina no período final.

Além disso, esse trabalho bem como outros, demonstrou que a reabsorção radicular não ocorre abaixo da área hialinizada no ligamento periodontal e sim em áreas adjacentes a hialinização (RYGH, 1977; BRUDVIK e RYGH, 1993a,b; HELLSING e HAMMARSTROM,1996). Áreas de cemento com aspecto normal alternam-se com áreas de reabsorção radicular, apesar de que as reabsorções radiculares foram encontradas nos terços médio e apical, enquanto que a hialinização foi mais freqüentemente observada no terço cervical. Uma possível explicação para esse fato é que o terço cervical é coberto por cemento acelular de fibras extrínsecas, onde muitas fibras colágenas (fibras de Sharpey) estão inseridas. Esta condição pode prevenir uma sobrecompressão da superfície radicular diminuindo assim a tendência de reabsorção nesta região (TEN CATE, 1976).

A reabsorção radicular durante a movimentação ortodôntica é encontrada nas áreas de compressão do ligamento periodontal (RYGH, 1973). O processo de reabsorção radicular é um efeito colateral da atividade celular associada à remoção dos tecidos necróticos do ligamento periodontal. Células 
multinucleadas sem borda em escova, bem como macrófagos, são os responsáveis pela remoção dos tecidos necróticos e também iniciariam a reabsorção de parte da superfície do cemento. Clastos são responsáveis pela fase seguinte da reabsorção radicular, não interferindo na remoção dos tecidos necróticos (BRUDVIK e RYGH, 1994). A histoquímica para a enzima TRAP permitiu identificar os clastos que reabsorviam o tecido ósseo e a superfície radicular. No presente trabalho foi possível encontrar muitos macrófagos em áreas hialinizadas no ligamento periodontal removendo os restos celulares.

A identificação de áreas onde zonas hialinizadas são substituídas por componentes normais do ligamento periodontal, revelam que a reparação tecidual ocorre, mesmo com a manutenção da força, durante a movimentação ortodôntica. Desse modo, os presentes achados coincidem com resultados prévios em humanos que também utilizaram forças contínuas (FALTIN et al., 2001; CASA et al., 2001).

A reparação observada não foi restrita ao ligamento periodontal, sendo também observada no cemento. Muitos trabalhos foram realizados avaliando a reparação radicular, porém a maioria deles avaliou a reparação após a remoção da biomecânica, pois se acreditava que a reparação só era possível quando a força era removida ou diminuída (RYGH, 1977; BRUDVIK e RYGH, 1995; OWMAN-MOLL et al., 1995). Outros trabalhos, no entanto, demonstram a reparação simultaneamente com o processo de reabsorção radicular durante a aplicação de forças contínuas (KUROL et al., 1997; CASA et al., 2006; JIMENEZ-PELLEGRIN e ARANA-CHAVEZ, 2007). As reabsorções radiculares ocorreram a partir do $15^{\circ}$ dia e, em tempos prolongados, atingiram a dentina, e não foram totalmente reparadas, pois estas são consideradas irreversíveis (ABELLEIRA et al., 1999).

A osteopontina foi analisada ultra-estruturalmente durante a movimentação ortodôntica e confirma a idéia de que esta proteína está presente em grandes quantidades quando há "stress" mecânico (ISHIJIMA et al., 2001; MORINOBU et al., 2003). 
Alguns autores sugerem que a presença da OPN recobrindo a matriz mineralizada é importante para a adesão da nova camada de matriz óssea que será depositada no estágio seguinte da remodelação óssea fisiológica, na fase de formação. Segundo essa hipótese, a OPN, presente nas linhas cimentantes, agiria promovendo a adesão entre o osso novo e o osso pré-existente (McKEE e NANCI, 1995). No presente estudo, a OPN foi encontrada em grandes quantidades em ambas as superfícies, óssea e radicular, formando camadas equivalentes às lâminas limitans, porém, mais espessas do que aquelas observadas na remodelação/reparação normal (NANCI, 1999). Assim, quando nova matriz era depositada sobre essas superfícies, as linhas cimentantes resultantes ricas em OPN também eram espessas. Esse padrão tinha sido anteriormente encontrado por Bonafe-Oliveira (2006) em períodos iniciais, utilizando o mesmo modelo experimental em ratos, confirmando a abundante deposição de OPN sobre as superfícies previamente reabsorvidas em locais de estresse mecânico contínuo.

Essa forte imunoreatividade nas superfícies mineralizadas que foram reabsorvidas levanta novamente a questão sobre à origem da OPN presente nesses locais, assunto em que existe uma controvérsia muito grande. Sodek et al. (2000), postulam que os osteoblastos seriam as células responsáveis pela sua síntese e secreção; já Dodds et al. (1995) afirmam ser os osteoclastos os responsáveis pela síntese e secreção de OPN. No presente estudo não foi detectada a presença de OPN no citoplasma dos osteoblastos ou cementoblastos, nem na zona clara, na borda em escova e nem no interior do citoplasma das células clásticas, sugerindo que nessa situação essas células não secretaram OPN. Parece possível, portanto, a teoria que sugere que a OPN atingiria estas superfícies proveniente da circulação (NANCl et al., 2004; BONAFE-OLIVEIRA, 2006).

A OPN está presente na superfície radicular (BOSSHARDT et al., 1998) e em situações onde há stress mecânico sua expressão é aumentada (HUANG et al., 2008). No presente estudo, foi encontrada OPN em todo o cemento do grupo controle e na superfície do cemento do grupo que sofreu movimentação 
ortodôntica confirmando a idéia de que esta proteína está presente na superfície do cemento previamente reabsorvido.

Em suma, os resultados mostram que mesmo com a aplicação de uma força "fisiológica" contínua ocorrem reabsorções radiculares com diferentes graus de severidade, coincidentes com a severidade da hialinização no ligamento periodontal adjacente. 
7 CONCLUSÃO 
De acordo com os resultados obtidos no presente estudo podemos concluir que mesmo com a aplicação de uma força "fisiológica" contínua ocorrem reabsorções radiculares com diferentes graus de severidade, dependendo do tempo que a força é mantida. No entanto, mesmo com a força permanecendo constante durante todo o experimento foi observada a reparação do cemento.

A osteopontina (OPN) esteve presente tanto no tecido ósseo, sugerindo seu importante papel na remodelação óssea induzida, como no cemento, mostrando indícios de participação no processo de reabsorção radicular e reparação das lacunas previamente reabsorvidas. 


\section{REFERÊNCIAS BIBLIOGRÁFICAS}

ABElleirA, A. C.; COBOS, M. A. R.; BOQUETE, I. M. F.; OREJA M. T. C.; BARREIRO, F. J. J.; PATO R. B. R. Morphological study of root surfaces in teeth with adult periodontitis. J. Periodontol., v. 70, p. 1283-1291, 1999.

ARANA-CHAVEZ, V. E., BRADASCHIA-CORREA V. Clastic cell:Mineralized tissue resorption in health and disease. Int. J. Biochem. Cell Biol. In press.

ARANA-CHAVEZ, V. E; NANCI, A. High-resolution immunocytochemistry of noncollagenous matrix proteins in rat mandibles processed with microwave irradiation. J. Histochem. Cytochem., v. 49, p.1099-1109, 2001.

ARANA-CHAVEZ, V. E.; SOARES, A. M. V.; KATCHBURIAN E. Junctions between early developing osteoblasts of rat calvaria as revealed by freeze-fracture and ultrathin section electron microscopy. Arch. Histol. Cytol., v.58, p.285-292 ,1995.

BEERTSEN, W.; MCCULLOCH, C. A.; SODEK, J. The periodontal ligament: a unique, multifuncional connective tissue. Peridontol. 2000., v. 13, p. 20-40,1997.

BERKOVITZ, B. K. B. Peridontal ligament: Structural and clinical correlates. Dent. Update, p. 46-54, 2004.

BONAFE-OLIVEIRA, L.; FALTIN, R. M.; ARANA-CHAVEZ, V. E. Ultrastructural and histochemical examination of alveolar bone at the pressure areas of rat molars submitted to continuous orthodontic force. Eur. J. Oral Sci., v. 111, p. 410-416, 2003.

BONAFE-OLIVEIRA, L. Estudo ultra-estrutural e imunocitoquímico das respostas periodontais frente a estímulo ortodôntico contínuo de vestibularização em molares de ratos. 148 p. Tese (Doutorado em Biologia Celular e do Desenvolvimento) Instituto de Ciências Biomédicas, Universidade de São Paulo, São Paulo, 2006.

De acordo com:

ASSOCIAÇÃO BRASILEIRA DE NORMAS TÉCNICAS. NBR 6023: Informação e documentação: elaboração. Rio de Janeiro, 2002. 
BOSSHARDT, D.D.; SCHROEDER, H.E. Cementogenesis rewied: a comparison between human premolars and rodent molars. Anat. Rec., v. 245, n.2, p. 267-92,1996.

BOSSHARDT, D. D.; ZALZAL, S.; McKEE, M. D.; NANCI, A. Developmental appearance and distribution of bone sialoprotein and osteopontin in human and rat cementum. Anat. Rec., v. 250, p. 13-33, 1998.

BREZNIAK, N.; WASSERSTEIN, A. Orthodontically induced inflammatory root resorption. Part I: the basic science aspect. Angle Orthod., v. 72, p. 175-179, 2002.

BRUDIVIK, P.; RYGH, P. The initial phase of orthodontic root resoption incident to local compression of the periodontal ligament. Eur. J. Orthod., v.15, p. 249-263, 1993a.

BRUDIVIK, P.; RYGH, P. Non-clast cells start orthodontic root resorption in the periphery of hyalinized zones. Eur. J. Orthod., v.15, p. 467-479, 1993 b.

BRUDIVIK, P.; RYGH, P. Multi-nucleated cells remove the main hyalinized tissue and start resorption of adjacent root surfaces. Eur. J. Orthod.; v.16, p. 265-173, 1994a.

BRUDIVIK, P.; RYGH, P. Root resorption beneath the main hyalinized zone. Eur. J. Orthod., v. 16, p. 249-263, 1994 b.

CARNEIRO, J.; DE MORAES, F. F. Radioautographic visualization of collagen metabolism in the periodontal tissues of the mouse. Arch. Oral Biol., v. 10, p. 833-848, 1965.

CASA, M. A.; FALTIN, R. M.; FALTIN, K.; SANDER F. G.; ARANA-CHAVEZ, V. E. Root resorptions in upper first premolars after application of continuous torque moment. Intra individual study. J. Orofac. Orthop., v. 62, p. 285-295, 2001.

CASA, M. A.; FALTIN, R. M.; FALTIN, K.; ARANA-CHAVEZ, V. E. Root resorption on torqued human premolars shown by tartrate-resistant acid phosphatase histochemistry and transmission electron microscopy. Angle Orthod., v. 76, n.6, p.1015-21, 2006. 
CHUNG, C. J.; SOMA, K.; RITTLING, S. R.; DENHARDT D. T.; HAYATA, T.; NAKASHIMA, K.; EZURA, Y.; NODA, M. OPN deficiency suppresses appearance of odontoclastic cells and resorption of the tooth root induced by experimentel force application. J. Cell. Physiol., v. 214, p. 614-620, 2008.

COLE, A. A.; WALTERS, L. M. Tartrate-resistant acid phosphatase in bone and cartilage following decalcification and cold-embedding in plastic. J. Histochem. Cytochem., v.35, p. 203-206, 1987.

DENHARDT, D. T.; NODA, M. Osteopontin expression and function: role in bone remodeling. J. Cell Biochem. Suppl., v. 30-31, p. 92-102, 1998.

DELAISSE, J. M.; ANDERSEN, T. L.; ENGSIG, M. T.; HENRIKSEN, K.; TROEN, T.; BLAVIER, L. Matrix metalloproteinases (MMP) and cathepsin K contribute differently to osteoclastic activities. Microsc. Res. Tech., v.61, p.504-513, 2003.

EMBERY, G. An update on the biochemistry of the periodotal ligament. EUR. J. ORTHOD., v. 12, n.1, p.77-82, 1990.

FALTIN, R. M.; ARANA-CHAVEZ, V. E.; FALTIN, K.; SANDER, F. G.; WICHELLAUS, A. Root resorption in upper first premolars after application of continuous intrusive forces. J. Orofac. Orthop., v.59, p. 208-219, 1998.

FALTIN, R. M.; FALTIN, K.; SANDER, F. G.; ARANA-CHAVEZ, V. E. Ultrastructure of cementum and periodontal ligament after continuous intrusion in humans: a transmission electron microscopy study. Eur. J. Orthod., v. 23, p. 35-49, 2001.

FRANZ-ODENDAAL, J. A.; HALL, B. K.; WITTEN, P. E. Buried alive: how osteoblasts become osteocytes. Dev. Dyn., v. 235, p.176-190, 2006.

FUJIHARA, S.; YOKOZEKI, M.; OBA, Y.; HIGASHIBATA, Y.; NOMURA, S.; MORIYAMA, K. Function and regulation of osteopontin in response to mechanical stress. J. Bone Miner. Res., v. 21, p. 956-964, 2006.

GIACHELLI, C. M.; STEITZ, S. Osteopontin: a versatile regulator of inflammation and biomineralization. Matriz Biol., v. 19, p. 615-621, 2000. 
GIL, F. J.; PLANELL, J. A. Effect of cooper addition on the superelastic behavior of Ni-Ti shape memory alloys for orthodontic applications. J. Biomed. Mater. Res., v. 48, p.682-88, 1999.

GONZALES, C.; HOTOKEZABA, H.; YOSHIMATSU, M.; YOZGATIAN, J.H.; DARENDELLIER, M. A.; YOSHIDA, N. Force magnitude and duration effects on amount of tooth movement and root resorption in the rat molar. Angle Orthod., v. 78, p. 502-509, 2008.

GRZEZIK, W. J.; NARAYANAN, A. S. Cementun and periodontal wound healing and regeneration. Crit. Rev. Oral Biol. Med., v. 13, p. 474-484, 2002.

GURGEL, J. A.; KERR, S.; POWERS J. M.; LECRONE V. Force deflection properties of superelastic nickel-titanium archwires. Am. J. Orthod. Dentof. Orthop., v.120, p.378-382, 2001a.

GURGEL, J. A.; RAMOS, A. L; KERR, S. D. Fios ortodônticos. Rev. Dental Press, v. 6, p.103-114, 2001b.

HELLSING, E.; HAMMAMASTRÖM, L. The hyaline zone and associated root surface changes in experimental orthodontics in rats: a light and scanning electron microscopy study. Eur. J. Orthod., v. 18, p. 11-18, 1996.

HILL, P. A. Bone remodeling. Br. J. Orthod., v.25, p.101-107, 1998.

HIRASHITA, A. The aspect of ultrastructural changes of the osteoblasts and surface areas of alveolar bone appearing in experimental tooth movement. Bull. Tokyo Med. Uni., v. 23, p. 245-260, 1976.

HOLLENDER, L.; RONNERMAN, A.; THILANDER, B. Root resorption, marginal bone support and clinical crown length in orthodontically treated patients. Eur $\mathbf{J}$ Orthod., v. 2, p. 197-205, 1980.

HUANG, L.; MENG, Y.; REN, A.; HAN, X.; BAI, D.; BAO, L. Response of cementoblast-like cells to mechanical tensile or compressive stress at physiological levels in vitro. Mol. Biol. Rep. In Press. 
ISHIJIMA, M.; RITTLING, S. R.; YAMASHITA, T.; TSUJI, K.; KUROSAWA, H.; NIFUJI, A.; DENHARDT, D. T.; NODA, M. Enhancement of osteoclastic bone resorption and suppression of osteoblastic bone formation in response to reduced mechanical stress do not occur in the absence of osteopontin. J. Exp. Med., v. 193, p. 399-404, 2001.

JAEGER, A.; KUNERT,D.; FRIESEN,T.; ZHANG,D.; LOSSDORFER,S.; GOTZ,W. Cellular and extracellular factors in early root resorption repair in the rat. Eur $\mathbf{J}$ Orthod., v. 30, p. 336-345, 2008.

JIMENEZ-PELLEGRIN, C., ARANA-CHAVEZ, V. E. Root resorption repair in mandibular first premolars after rotation. A transmission electron microscopy analysis combined with immunolabeling of osteopontin. Am J Orthod Dentofac Orthop., v. 2, p. 230-236, 2007.

JIMENEZ-PELLEGIRN, C.; ARANA-CHAVEZ, V. E. Root resorption in human mandibular first premolars after rotation as detected by scanning electron microscopy. Am J Orthod Dentofac Orthop., v. 2, p. 178-184, 2004.

KAPILA, S.; SACHDEVA, R. Mechanical properties and clinical applications of orthodontic wire. Am. J. Orthod. Dentof. Otrhop., v. 96, p.100-108, 1989.

KATCHBURIAN, E.; ARANA-CHAVEZ, V. E. Histologia e embriologia oral: textoatlas-correlações clínicas. 2. ed. Buenos Aires: Médica Panamericana, 2004, p. 372.

KOHNO, T.; MATSUMOTO, Y.; KANNO, Z.; WARITA, H.; SOMA, K. Experimental tooth movement under light orthodontic forces: rates of tooth movement and changes of the periodontium. J. Orthod., v. 29, p.129-135, 2002.

KÜROL, J.; OWMAN-MOLL, P.; LUNDGREN, D. Time-related root resorption after application of a controlled continuous orthodontic force. Am. J. Orthod. Dentofac. Orthop., v. 110, p. 303-310, 1996.

KUSY, R. P. A review of contemporany archwires: their properties and characteristics. Angle Orthod., v. 67, p.197-208, 1997.

LANGFORD, S. R. Root resorption extremes resulting from clinical RME. Am. J. Orthod. v. 11, p. 371-377, 1982. 
LERNER, U. H. Osteoclast formation and resorption. Matrix Biol., v. 19, p. 107-20, 2000.

LEKIC, P.; MCCULLOCH, C. A. G. Periodontal ligament cell populations: the central role of fibroblasts in creating a unique tissue. Anat. Rec., v. 245, p. 327-41, 1996.

LILJA, E.; ODENRICK, L. Root resorption following slow maxillary expansion. Swed. Dent. J., v. 15, p- 123-129, 1982.

MASSA, L.; ARANA-CHAVEZ, V. E. Ultrastructural preservation of rat embryonic dental tissues after rapid fixation and dehydration under microwave irradiation. Eur. J. Oral Sci., v.108, p.74-77, 2000.

MAVRAGANI, M.; AMUNDSEN, O. C.; SELLISETH, N. J.; BRUDVIK, P.; SELVIG, K. A. Early root alterations after orthodontic force application studied by light and scanning electron microscopy. Eur. J. Orthod., v. 26, p. 119-128, 2004.

McKEE, M. D.; NANCI A. Osteopontin and the bone remodeling sequence. Coloidalgold immunocytochemistry of an interfacial extracellular matrix protein. Ann. N. Y. Acad. Sci., v. 21, p. 177-189, 1995.

McKEE, M. D.; NANCI, A. Osteopontin at mineralized tissue interfaces in bone, teeth and osseointegrated implants: ultrastructural distribution and implications for mineralized tissue formation, turnover, and repair. Micros. Res. Tech., v. 33, p. 141164, 1996a.

McKEE, M. D.; NANCI, A. Osteopontin: an interfacial extracellular matrix protein in mineralized tissues. Connect. Tissue Res., v. 35, p.197-205, 1996 b.

McKEE, M. D.; NANCI, A. Secretion of osteopontin by macrophages and its accumulation at tissue surfaces during wound healing in mineralized tissues: A potential requirement for macrophage adhesion and phagocytosis. Anat. Rec., v. 245, p. 394-409, 1996c. 
MIRABELLA, A. D.; ARTUN, J. Prevalence and severity of apical root resorption of maxillary anterior teeth in adult orthodontic pacients. Eur. J. Orthod., v. 17, p. 93-99, 1995.

MIURA, F.; OHURA, Y.; HAMANAKA, H. The super-elastic property of Japanese NiTi alloy for use in orthodontics. Am. J. Orthod. Dentof. Otrhop., v. 90, p. 1-10, 1986.

MORINOBU, M.; ISHIJIMA, M.; RITTILING, S. R.; TSUJI, K.; YAMAMOTO, H.; NIFUJI, A.; DENHARDT, D. T.; NODA M. Osteopontin expression in osteoblast and osteocytes during bone formation under mechanical stress in the calvarial suture in vivo. J. Bone Miner. Res., v. 9, p. 1706-1715, 2003.

MULARI, M.; VÄÄRÄNIEMI, J.; VÄÄNÄNEN, H. K. Intracellular trafficking in bone resorbing osteoclasts. Micros. Res. Tech., v. 61, p. 496-453, 2003.

NAKANO, H.; SATOH, K.; NORRIS, S.; JIN T.; KAMEGAI, T.; ISHIKAWA, F.; KATSURA, H. Mechanical properties of several nickel-titanium alloy wires in threepoint bendig tests. Am. J. Orthod. Dentofac., v. 115, p. 390-3955, 1999.

NAKANE, S.; KAMEYAMA, Y. Root resorption caused by mechanical injury of periodontal soft tissues in rat. J. Period Res., v. 22, p. 390-395, 1987.

NANCI, A.; BOSSHARDT, D. Strucutre of periodontal tissue in health and disease. Periodontol. 2000, v.10, p. 11-28, 2006.

NANCI, A. Content and distribuition of noncollagenous matrix proteins in bone and cementum: relationship to speed of formation and collagen packing density. J Struct Biol. v.30; p.256-69, 1999.

OHM, L. B.; LINGE, L. Apical root resorption in upper anterior teeth. Eur. J. Orthod., v. 5, p. 173-183, 1982.

OPPENHEIN, A. A. Possibility for physiologic orthodontic movement. Am. J. Orthod. Oral Surg., v. 30, p. 277-332, 1944. 
OWMAN-MOLL, P.; KUROL, J.; LUNDGREN, D. Continuous versus interrupted continuous orthodontic force related to early tooth movement and root resorption. Angle Orthod., v. 65, p. 395-402, 1995.

OWMAN-MOLL, P.; KUROL, J.; LUNDGREN, D. The effects of a four-fold incresead orthodontic force magnitude on tooth movement and root resorptions. An intra-individual study in adolescent. Eur. J. Orthod., v. 18, p. 287-294, 1996a.

OWMAN-MOLL, P.; KUROL, J.; LUNDGREN, D. Effects of a doubled orthodontic force magnitude on tooth movement and root resorptions. An inter-individual study in adolescent. Eur. J. Orthod. v. 18, p 141-150, 1996 b.

PHILLIPS, J. R. Apical root resorption under orthodontic therapy. Angle Orthod., v. 25, p. 1-22, 1995.

PICTON, F. C. Paracervical nerve block in labour. Br. J. Clin. Pract. v.23, p.162-164, 1969.

PIZZO, G.; LICATA, M. E.; GIULIANA, G. Root resorption and orthodontic treatment. Minerva Stomatol., v. 56, p. 31-44, 2007.

REITAN, K. The initial tissue reaction incident to orthodontic tooth movement as related to the influence of function. Acta Odontol. Scand., v. 6, p.1-19, 1951.

REITAN, K. Tissue behavior during orthodontic tooth movement. Am. J. Orthod., v. 46, p. 881-890, 1960.

REITAN, K. Initial tissue behavior during apical root resorption. Angle Orthod., v. 44, p. 68-82, 1974.

REITAN, K. Tissue reactions in orthodontics. In: Graber, T.M, Vanarsdall, R.L, Vig, K.W.L. 4. ed. Orthodontics current principles and techiniques. St Louis: CV Mosby, 2005, p. 249-263.

REINHOLT, F. P.; HULTENBY, K.; OLDBERG, A.; HEINEGARD, D. Osteopontin a possible anchor of osteoclast to bone. Proc. Natl. Acad. Sci., v. 87, p. 4473-4475, 1990. 
REN, Y.; MALTHA, J. C.; KUIJPERS-JAGTMAN, A. M. The rat as a model for orthodontic tooth movement - a critical review and proposed solution. Eur. J. Orthod., v. 26, p. 483-490, 2004.

RUDOLPH, D. J.; WILLES, P. M. G.; SAMESHIMA, G. T. A finite element model of apical force distribution from orthodontic tooth movement. Angle Orthod., v. 71, p. 127-131, 2001.

RYGH, P. Ultrastructural vascular changes in pressure zones of rat molar periodontium incident to orthodontic movement. Scand. J. Dent. Res., v. 80, p. 307-321, 1972a.

RYGH, P. Ultrastructural cellular reactions in pressure zones of rat molar periodontium incident to orthodontic tooth movement. Acta Odontol. Scand., v. 30, p. 575-593, $1972 b$.

RYGH, P. Ultrastructural changes in pressure zones of human periodontium incident to orthodontic tooth movement. Acta Odontol. Scand., v.31, p. 109-122, 1973.

RYGH P. Elimination of hyalinized periodontal tissues associated with orthodontic tooth movement. Scand. J. Dent. Res., v.82, p.57-73, 1974.

RYGH, P. Ultrastructural changes in tension zones of rat molar periodontium incident to orthodontic tooth movement. Am. J. Orthod., v. 70, p.269-81, 1976.

RYGH P. Orthodontic root resorption studied by electron microscopy. Angle Orthod., v. 47, p. 1-16, 1977.

ROODMAN G. D. Regulation of osteoclast differentiation. Ann. N.Y. Acad. Sci., v. 1068, p. 100-109, 2006.

SAYGIN N. E.; GIANNOBILE W. V.; SOMERMAM M. J. Molecular and cell biology of cementum. Periodotol. 2000, v. 24, p. 73-98, 2000.

SCHWARZ, A. M. Tissue changes incidental to tooth movement. Int. J. Orthod., v. 18, p. 331-352, 1932. 
SMITH, R. J.; BUSRTONE, C. J. Mechanics of tooth movement. Am. J. Orthod., v. 85, p. 294-330, 1984.

SODEK, J.; GANSS, B.; McKEE, M. D. Osteopontin. Crit. Rev. Oral Biol. Med., v. 11, p.279-303, 2000.

STEIGMAN, S.; MICHAELI, Y. Experimental intrusion of rat incisors with continuous loads of varying magnitude. Am. J. Orthod. Dentofac. Orthop., v. 80, p. 429-436, 1981.

TERAI, K.; YAMAMOTO-TAKANO, T.; OHBA, Y.; HIURA, K.; SUGIMOTO, M.; SATO M., KAWAHATA H., INAGUMA N., KITAMURA Y., NOMURA S. Role of osteopontin in bone remodeling caused by mechanical stress. J. Bone Miner. Res. v. 14, p. 839-849, 1999.

THILANDER, B.; RYGH, P.; REITAN, K. Tissue Reactions in orthodontics. In: GRABER, T.M.; VANARSDALL, R. L.; VIG, K. W. L. Orthodontics: Currents principles and techiniques. 4. ed. St Louis: CV Mosby: 2005, p.145-217.

TEN CATE, A. R. Histologia bucal. Desenvolvimento, estrutura e função. 5. ed. Rio de Janeiro: Guanabara Koogan, 2001, p. 20-43.

TENORIO, D.; CRUCHLEY, A.; HUGHES, F. J. Immunihistochemical investigation of the rat cementoblast phenotype. J. Periodontal Res., v. 28, n.6 Pt 1, p. 411-19, 1993.

VERNA, C.; DALSTRA, M.; MELSEN B. The rate and the type of orthodontic tooth movement is influenced by bone turnover in a rat model. Eur. J. Orthod., v.22, p. 343$352,2000$.

WARSHAWSKY, H.; MOORE, G. A technique for the fixation and decalcification of rat incisors for electron microscopy. J. Histochem. Cytochem., v.15, p.542-549, 1967.

WICHELHAUS, A.; SANDER, F. G. Das Verhalten von superelastichen Drähten im elastichen und plastichen Bereich. Abhängigkeit von der Termperatur. Kieferorthop Mitt, v. 6, p. 95-106, 1994. 